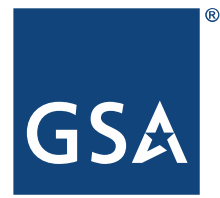

Prepared for the General Services Administration By the National Renewable Energy Laboratory

NOVEMBER 2021

\title{
Demonstration and Evaluation of Lightweight High Performance Secondary Windows
}

Kosol Kiatreungwattana (NREL)

Lin Simpson (NREL) 


\section{Disclaimer}

This document was prepared as an account of work sponsored by the United States Government. While this document is believed to contain correct information, neither the United States Government nor any agency thereof, nor the National Renewable Energy Laboratory, nor any of their employees, makes any warranty, express or implied, or assumes any legal responsibility for the accuracy, completeness, or usefulness of any information, apparatus, product, or process disclosed, or represents that its use would not infringe privately owned rights. Reference herein to any specific commercial product, process, or service by its trade name, trademark, manufacturer, or otherwise does not constitute or imply its endorsement, recommendation or favoring by the United States Government or any agency thereof, or the U.S. Department of Energy's National Renewable Energy Laboratory. The views and opinions of authors expressed herein do not necessarily state or reflect those of the United States Government or any agency thereof or the National Renewable Energy Laboratory.

The work described in this report was funded by the U.S. General Services Administration and the Federal Energy Management Program of the U.S. Department of Energy under Contract No. IAG-11-01815.

\section{Acknowledgements}

U.S. General Services Administration (GSA) Region 8: Tyler Cooper, Douglas Baughman GSA Proving Ground Program: Michael Lowell and Kevin Powell Alpen High Performance Products: Brad Begin, Craig Maierhofer, Robert Clark, Dwayne Kowaliuk National Renewable Energy Laboratory: Kosol Kiatreungwattana, Lin Simpson, Jesse Dean Mountain Energy Partnership: Ed Hancock, Greg Barker and Paul Norton Tenfold Information Design Services: Andrea Silvestri

\section{For more information contact:}

Michael Lowell

General Services Administration

Email: mike.lowell@gsa.go

NREL/TP-5R00-79112 


\section{Executive Summary}

This demonstration project assessed the thermal performance, life cycle costs, and deployment potential of two types of window inserts, or "secondary windows," to be used in conjunction with existing, older single-pane windows.

\section{A. BACKGROUND AND OVERVIEW OF THE TECHNOLOGY}

The U.S. Department of Energy's (DOE) National Renewable Energy Laboratory evaluated the secondary windows at the U.S. General Services Administration's (GSA) Denver Federal Center Building 53 in Denver, Colorado. For this study, ten secondary windows (single-pane and double-pane secondary windows) were installed at Building 53.

Several different evaluations assessed the viability of the secondary windows for GSA applications. Some of these assessments were performed with models, while others required onsite evaluations including time series measurements.

\section{B. STUDY DESIGN AND OBJECTIVES}

The primary objectives of the onsite measurement and verification study include:

Objective 1. Verify the benefits of the high performance secondary windows, including:

a. Thermal performance

b. Heating, ventilating and air conditioning (HVAC) energy reduction

c. Thermal load (cooling and heating) reduction

d. Comfort improvement

Objective 2. Economic analysis (savings to investment ratio $[\mathrm{SIR}]$ and payback)

Objective 3. Evaluate ease of installation and operability

Objective 4. Assess the deployment potential for other GSA sites and identify screening criteria for future candidate buildings and climate zones.

Quantitative objectives and results are provided in Table ES-1 and qualitative performance objectives for the project are provided in Table ES-2.

\section{Table ES-1: Quantitative Objectives and Results}
Quantitative
Objectives
Metrics \& Data
Success Criteria
Results

\begin{tabular}{|c|c|c|c|}
\hline Energy Savings & $\begin{array}{l}\text { HVAC energy } \\
\text { consumption } \\
\text { (modeled), kBtu }\end{array}$ & $\begin{array}{l}\text { Energy savings compared to single- } \\
\text { pane window baseline } \\
10 \% \text { for HVAC energy usage }\end{array}$ & $\begin{array}{l}\text { HVAC energy savings compared to single- } \\
\text { pane window baseline } \\
\text { Single-pane secondary } \\
\text { - } \quad 20 \% \text { savings - PASS } \\
\text { Double-pane secondary } \\
\text { - } 40 \% \text { savings - PASS }\end{array}$ \\
\hline
\end{tabular}




\begin{tabular}{|c|c|c|c|}
\hline $\begin{array}{l}\text { HVAC Capacity } \\
\text { Reduction }\end{array}$ & $\begin{array}{l}\text { HVAC cooling capacity } \\
\text { (modeled), kBtu/hr } \\
\text { HVAC heating capacity } \\
\text { (modeled), kBtu/hr }\end{array}$ & $\begin{array}{l}\text { HVAC capacity }{ }^{a} \text { reduction } \\
\text { compared to a single-pane window } \\
\text { baseline } \\
\begin{array}{l}10 \% \text { for HVAC cooling and heating } \\
\text { loads }\end{array}\end{array}$ & $\begin{array}{l}\text { Single-pane secondary window } \\
\text { - } 10 \% \text { for heating capacity - PASS } \\
\text { - } \quad 8 \% \text { for cooling capacity - DID NOT } \\
\text { PASS } \\
\text { Double-pane secondary } \\
\text { - } 19 \% \text { for heating capacity - PASS } \\
\text { - } 13 \% \text { for cooling capacity - PASS }\end{array}$ \\
\hline $\begin{array}{l}\text { Cost- } \\
\text { Effectiveness }\end{array}$ & $\begin{array}{l}\text { Simple payback, years } \\
\text { SIR, no unit }\end{array}$ & $\begin{array}{l}<15 \text { years payback } \\
>1 \text { SIR }\end{array}$ & $\begin{array}{l}\text { Simple payback / Savings-to-investment } \\
\text { ratio } \\
\text { Single-pane secondary } \\
\text { - } 18.3 \mathrm{yr} \text { - DID NOT PASS } \\
\text { - } 1.1 \mathrm{SIR} \text { - PASS } \\
\text { Double-pane secondary } \\
\text { - } 10.7 \mathrm{yr} \text { - PASS } \\
\text { - } 1.9 \mathrm{SIR} \text { - PASS }\end{array}$ \\
\hline Condensation & $\begin{array}{l}\text { Room-side glass surface } \\
\text { temperature, }{ }^{\circ} \mathrm{F} \\
\text { Relative humidity, \% } \\
\text { Calculated } \\
\text { Condensation } \\
\text { Resistance (CR) rating, } \\
0-100\end{array}$ & $\begin{array}{l}\text { Condensation Resistance }(C R) \\
\text { rating greater than } 50\end{array}$ & $\begin{array}{l}\text { Condensation Resistance (CR) rating } \\
\text { Single-pane Secondary with baseline } \\
\text { Double-pane Secondary with baseline } \\
\qquad 46 \text { CR - DID NOT PASS } \\
\text { CR rating for the existing single-pane } \\
\text { window is low at } 12-14 \text { due to the fact that } \\
\text { it has inferior thermal performance. } \\
\text { Although the criteria was not met, the } \\
\text { secondary windows still improved overall } \\
\text { condensation rating significantly. }\end{array}$ \\
\hline
\end{tabular}




\begin{tabular}{|c|c|c|c|}
\hline $\begin{array}{c}\text { Quantitative } \\
\text { Objectives }\end{array}$ & Metrics \& Data & Success Criteria & Results \\
\hline Thermal Comfort & $\begin{array}{l}\text { Space temperature, }{ }^{\circ} \mathrm{F} \\
\text { and relative humidity, } \\
\% \\
\text { Room side glass surface } \\
\text { temperature, }{ }^{\circ} \mathrm{F} \\
\text { Wall temperature, }{ }^{\circ} \mathrm{F}\end{array}$ & $\begin{array}{l}\text { Space temperature and relative } \\
\text { humidity are within occupant } \\
\text { thermal comfort defined by } \\
\text { ASHRAE Standard } 55-2013\end{array}$ & $\begin{array}{l}\text { Both secondary windows - PASS } \\
\text { A small number of hours ( } 5 \text { to } 10 \% \text { ) that } \\
\text { were outside the comfort boundary }\end{array}$ \\
\hline
\end{tabular}

Table ES-2: Qualitative Objectives

\begin{tabular}{|c|c|c|c|}
\hline $\begin{array}{l}\text { Qualitative } \\
\text { Objectives }\end{array}$ & $\begin{array}{c}\text { Metrics \& } \\
\text { Data }\end{array}$ & Success Criteria & Results \\
\hline $\begin{array}{l}\text { Thermal } \\
\text { Comfort }\end{array}$ & $\begin{array}{l}\text { Tenant } \\
\text { satisfaction } \\
\text { survey }\end{array}$ & $\begin{array}{l}\text { Improvement in } \\
\text { tenant satisfaction } \\
\text { with thermal } \\
\text { conditions }\end{array}$ & $\begin{array}{l}\text { Building } \mathbf{5 3} \text { for secondary window } \\
\text { Five surveys received; } 3 / 5 \text { were positive and recommended } \\
\text { the retrofit. } 2 / 5 \text { did not have any opinion on the retrofit. } \\
\text { Thermal discomfort occurred and may be caused by HVAC } \\
\text { rather than the windows. } \\
\text { Secondary window appearance was noticeable but acceptable. }\end{array}$ \\
\hline $\begin{array}{l}\text { Ease of } \\
\text { Installation }\end{array}$ & $\begin{array}{l}\text { Interview with } \\
\text { installer } \\
\text { Time required to } \\
\text { install \& configure } \\
\text { Labor associated } \\
\text { with install }\end{array}$ & $<1$ day to install & $\begin{array}{l}\text { Installation of a secondary window, by one person, took } \\
\text { approximately } 7-10 \text { minutes to install. It could be easily } \\
\text { installed and uninstalled. PASS }\end{array}$ \\
\hline
\end{tabular}

The demonstration assessed the use of secondary windows for GSA applications. Several different evaluations assessed the viability of the secondary windows for GSA applications. Some of these assessments were performed with models, while others required onsite evaluations including time series measurements.

\section{PROJECT RESULTS AND FINDINGS}

The secondary windows operated as intended and most evaluation criteria were met. The secondary windows provide energy savings and are cost effective due to improved thermal performance.

Results, findings, and conclusions are summarized below.

- The secondary window can be quickly and easily installed with existing windows to provide a costeffective and efficient way to improve thermal performance and occupant comfort, especially when integrated with existing single-pane windows. The quick installation-compared to the process of replacing primary windows-minimizes disruption to the building occupants. 
- The secondary window can be a much less expensive alternative to replacing primary windows. In addition, the secondary windows are lightweight and thus suitable for structures that cannot handle additional weight.

- The technology is particularly useful in buildings or areas where planning rules do not allow any aesthetic changes to the external primary windows (e.g., historic buildings).

- Windows with the same U-value are manufactured with various levels of SHGC. SHGC should be appropriately selected for a climate zone. The lower the SHGC, the less solar heat it transmits and the greater its shading ability. A product with a high SHGC rating is more effective at collecting solar heat during the winter. A product with a low SHGC rating is more effective at reducing cooling loads during the summer by blocking heat gain from the sun.

- The calculated CR for the secondary window integrated with a baseline single-pane window is $44-46$. By a narrow margin, they did not pass the criteria. This shortfall may not necessarily be attributable to the secondary window, but rather to the existing single-pane window. Integration of the secondary window substantially improved CR as compared to the existing single-pane window, which has a CR rating of 1214 due to its inferior thermal performance. A CR over 50 indicates good condensation resistance.

- Other studies suggest that secondary windows can significantly reduce air infiltration, resulting in additional energy savings.

- The thermal comfort criteria are met as the results show that the majority of the indoor conditions were within the comfort boundary. However, the predicted mean vote and percentage of dissatisfied analysis shows that the space in Building 53 was slightly cool and predicts that $45 \%$ of the occupants could experience some local thermal discomfort. It is possible that thermal discomfort was already present and was caused by HVAC operation rather than the windows.

- Measured temperatures at the center of the glass during the coldest period show significant improvement due to the secondary window. The average temperatures at the center of the glass of double-pane and single-pane secondary windows during cold periods (mean outdoor temperature of $21^{\circ} \mathrm{F}$ ) are $68.2^{\circ} \mathrm{F}$ and $56.7^{\circ} \mathrm{F}$, respectively, compared a baseline single-pane window at $48^{\circ} \mathrm{F}$. Temperature differences increase radiant asymmetry, which contributes to occupant discomfort. ASHRAE 55 guidelines state that for vertical surfaces, radiant asymmetry should be kept to less than $18^{\circ} \mathrm{F}$ (ASHRAE 2020). Within this demonstration, the vertical-surface radiant asymmetry of the double-pane and single-pane secondary windows are within the ASHRAE guidelines. In addition, larger temperature differences between the window surface and indoor air can also induce convective heat transfer through air movement, particularly during cold conditions. Drafts caused by air movement can also contribute to occupant discomfort.

- Most thermal comfort survey responses were positive and recommended the secondary window retrofit in the future. The secondary windows' appearance was noticeable but acceptable.

- To evaluate deployment potential, we conducted energy savings and economic analyses through energy simulation modeling for ten ASHRAE climate zones (1A to 6A). The energy cost was estimated for three levels of GSA utility rates (low, medium, and high). Criteria include a payback period of less than 15 years and a SIR greater than 1 for both secondary windows. The results populated in Table 38 of this report can be used for future screening for the technology. However, for a future retrofit project, a detailed study including energy modeling analysis of the window options for the specific building is recommended due to the fact that each building is unique. Results and findings are summarized below. 


\section{Single-Pane Secondary Window}

Estimated Heating Energy (1)

- Heating energy reduction between $24 \%$ and $38 \%$

- Normalized heating energy savings from $0.4-7.6 \mathrm{kBtu} / \mathrm{ft}^{2} / \mathrm{yr}$

Estimated Cooling Energy (2)

- Cooling energy reduction between $6 \%$ and $10 \%$

- Normalized cooling energy savings from $0.3-1.0 \mathrm{kBtu} / \mathrm{ft}^{2} / \mathrm{yr}$

Estimated Fan Energy (3)

- Fan energy reduction between $8 \%$ and $12 \%$

- Normalized fan energy savings from 0.6-1.2 kBtu/ft ${ }^{2} / \mathrm{yr}$

Estimated HVAC Energy $(1+2+3)$

- HVAC energy reduction between $8 \%$ and $20 \%$

- Normalized HVAC energy savings from $1.9-8.8 \mathrm{kBtu} / \mathrm{ft}^{2} / \mathrm{yr}$

Estimated Total Building Energy

- Total building energy reduction between $3 \%$ and $10 \%$

- Normalized fan energy savings from 2.0-8.9 kBtu/ $\mathrm{ft}^{2} / \mathrm{yr}$

Estimated Total Building Energy Cost and Economics

- Normalized building energy savings:

○ $\$ 0.04-\$ 0.08 / \mathrm{ft}^{2} / \mathrm{yr}$ for low utility rate

○ $\quad \$ 0.06-\$ 0.12 / \mathrm{ft}^{2} / \mathrm{yr}$ for medium utility rate

○ $\$ 0.09-\$ 0.18 / \mathrm{ft}^{2} / \mathrm{yr}$ for high utility rate

- Payback period:

○ $\quad 21.9-44.6$ years for low utility rate

- $\quad 15.5-30.9$ years for medium utility rate

○ 10.1-19.5 years for high utility rate

- SIR:

○ $\quad 0.4-0.9$ for low utility rate

○ $\quad 0.6-1.3$ for medium utility rate

$\circ \quad$ 1.0-2.0 for high utility rate

\section{Double-Pane Secondary Window}

Estimated Heating Energy (1)

- Heating energy reduction between $43 \%$ and $94 \%$

- Normalized heating energy savings from $1.0-13.6 \mathrm{kBtu} / \mathrm{ft}^{2} / \mathrm{yr}$ 


\section{Estimated Cooling Energy (2)}

- Cooling energy reduction between $16 \%$ and $26 \%$

- Normalized cooling energy savings from $0.9-2.7 \mathrm{kBtu} / \mathrm{ft}^{2} / \mathrm{yr}$

Estimated Fan Energy (3)

- Fan energy reduction between $21 \%$ and $28 \%$

- Normalized fan energy savings from $1.6-2.9 \mathrm{kBtu} / \mathrm{ft}^{2} / \mathrm{yr}$

Estimated HVAC Energy $(1+2+3)$

- HVAC energy reduction between $21 \%$ and $40 \%$

- Normalized HVAC energy savings from 5.7-17.0 kBtu/ $\mathrm{ft}^{2} / \mathrm{yr}$

Estimated Total Building Energy

- Total building energy reduction between $8 \%$ and $20 \%$

- Normalized fan energy savings from $5.7-17.0 \mathrm{kBtu} / \mathrm{ft}^{2} / \mathrm{yr}$

Estimated Total Building Energy Cost and Economics

- Normalized building energy savings:

○ $\$ 0.11-\$ 0.18 / \mathrm{ft}^{2} / \mathrm{yr}$ for low utility rate

○ $\$ 0.16-\$ 0.26 / \mathrm{ft}^{2} / \mathrm{yr}$ for medium utility rate

○ $\$ 0.26-\$ 0.41 / \mathrm{ft}^{2} / \mathrm{yr}$ for high utility rate

- Payback period:

○ $\quad$ 12.5-20.4 years for low utility rate

○ 8.8-14.1 years for medium utility rate

○ 5.7-8.9 years for high utility rate

- SIR:

○ 1.0-1.6 for low utility rate

○ 1.4-2.3 for medium utility rate

○ 2.2-3.5 for high utility rate

Significant thermal improvements and smaller incremental costs of the double-pane secondary window as compared to the single-pane secondary window make the double-pane secondary window a good choice for future deployment in most climates. However, additional analysis indicated that the singlepane secondary window with low SHGC provided slightly better economic results than the double-pane secondary window at the same low SHGC for warm climates such as climate zone 1A. Therefore, the single-pane secondary window with low SHGC could also be a cost effective measure, particularly for warm climate zones. 


\section{Table of Contents}

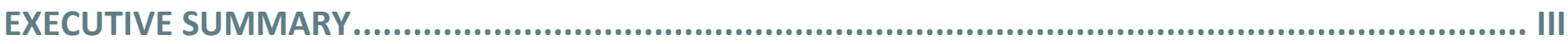

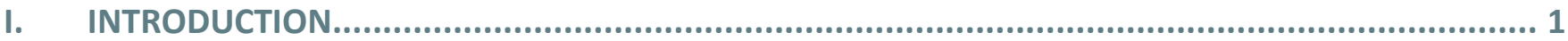

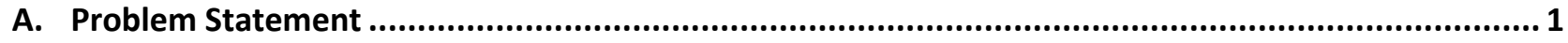

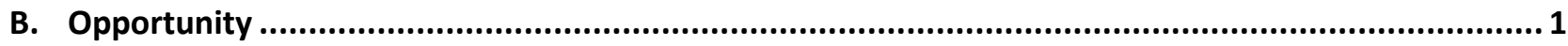

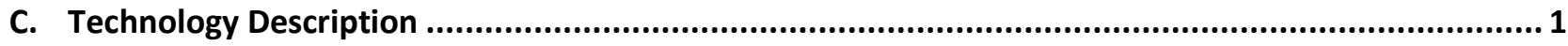

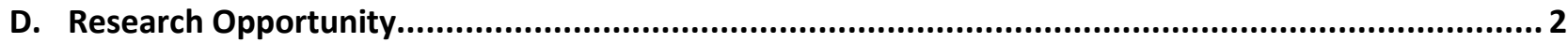

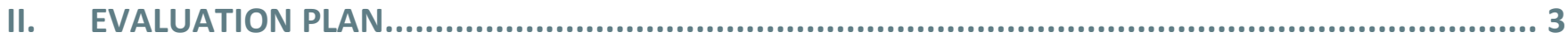

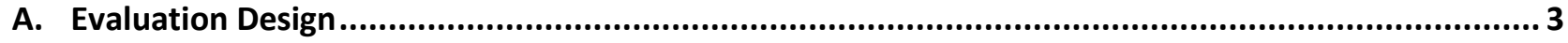

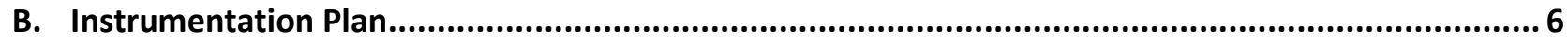

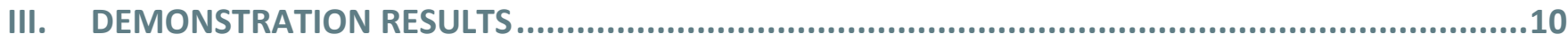

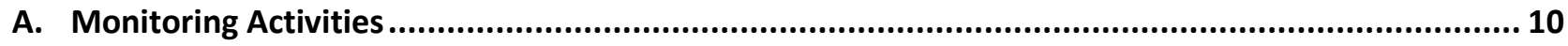

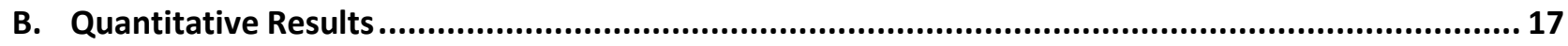

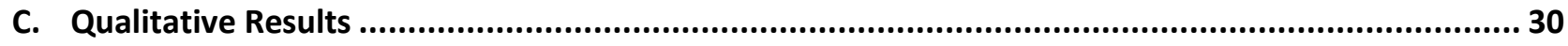

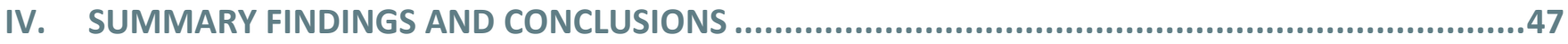

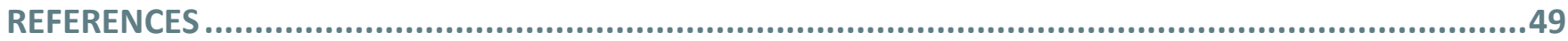

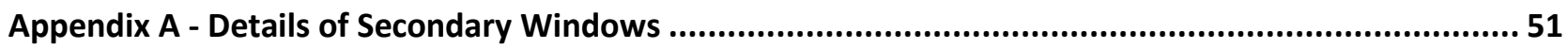

Appendix B - Secondary Window Weight Comparison ................................................................... 52

Appendix C - AERC Air Leakage Testing Results of Single- and Double-Pane Secondary Windows.......... 53

Appendix D - Infrared Thermography Field Measurements .............................................................5 58

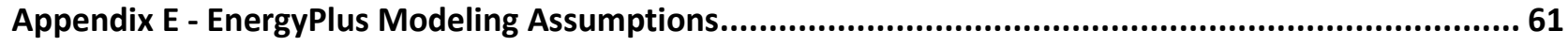

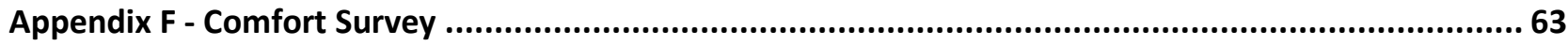

Appendix G - Additional Results for Medium Office ........................................................................66 


\section{List of Tables}

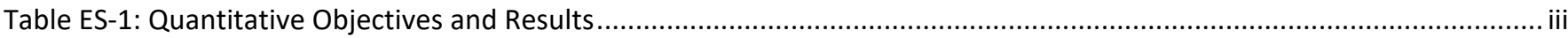

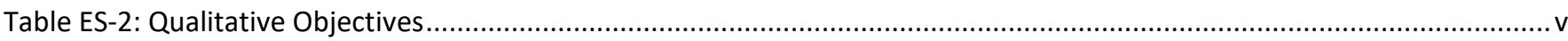

Table 1: U.S. Annual Commercial Building HVAC and Window-Related Energy Use, Reported in Quadrillion BTUs of Primary

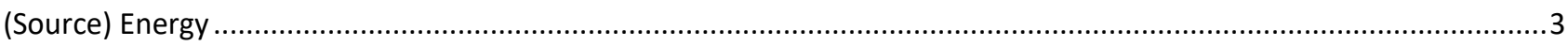

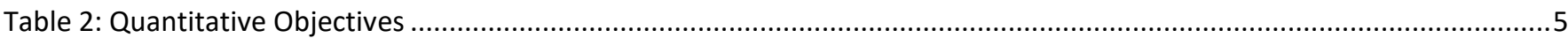

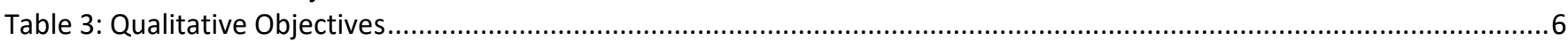

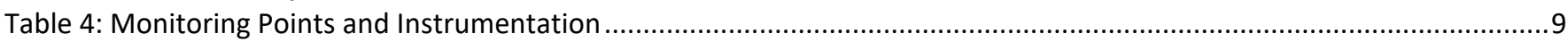

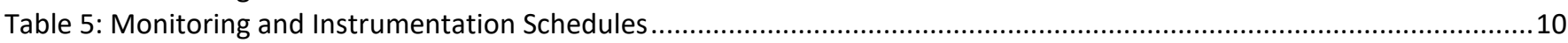

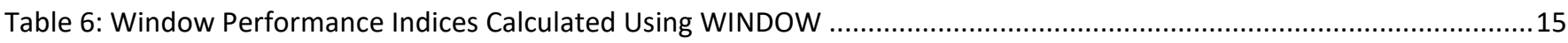

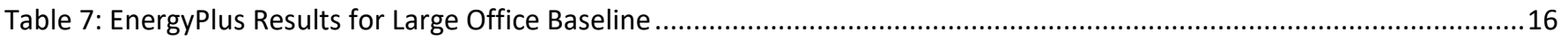

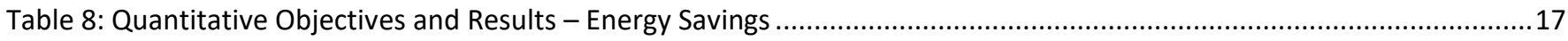

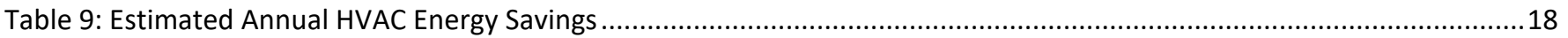

Table 10. Quantitative Objectives and Results - Thermal Performance Indices.............................................................18

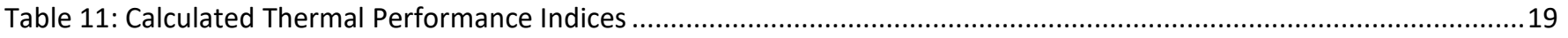

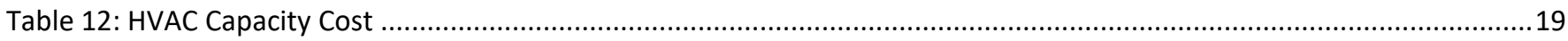

Table 13: Quantitative Objectives and Results - HVAC Capacity Reduction ...............................................................20

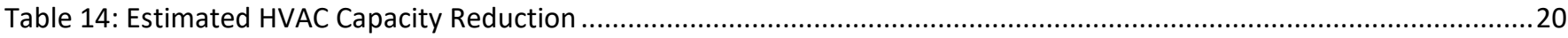

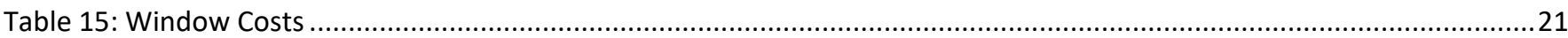

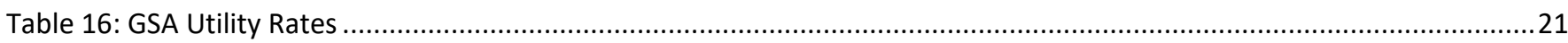

Table 17: Quantitative Objectives and Results - Cost Effectiveness ........................................................................21

Table 18: Cost Effectiveness - Simple Payback and Savings-to-Investment Ratio ..........................................................22

Table 19: Quantitative Objectives and Results - Condensation....................................................................................22

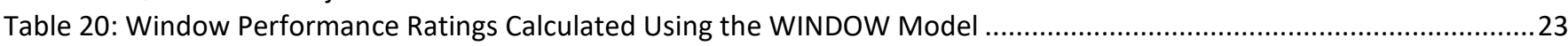

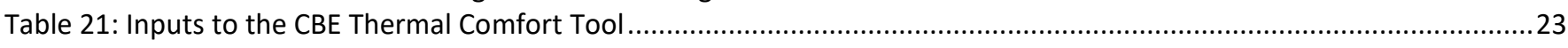

Table 22: Quantitative Objectives and Results - Thermal Comfort ...............................................................................27

Table 23: Average Surface Temperature During Cold Period ..........................................................................................28

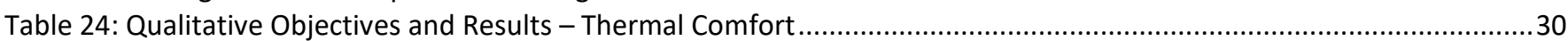

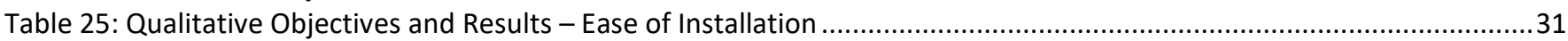

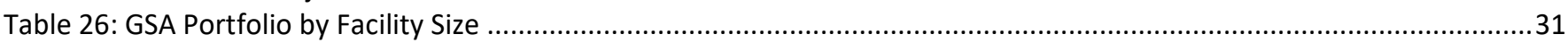

Table 27: Estimated Heating Energy, Normalized Heating Energy, and Heating Energy Savings............................................34

Table 28: Estimated Cooling Energy, Normalized Cooling Energy, and Cooling Energy Savings ...............................................35

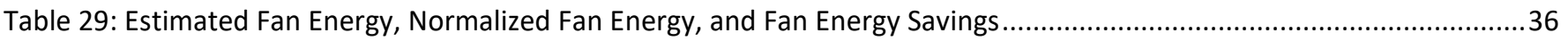

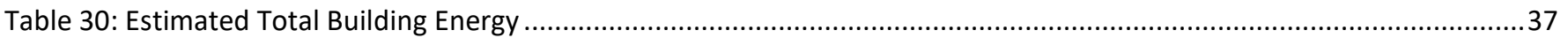

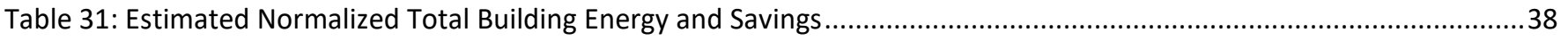

Table 32: Estimated Total Building Energy Cost - Low Utility Rate ....................................................................................39

Table 33: Estimated Normalized Total Building Energy Cost - Low Utility Rate ..............................................................40

Table 34: Estimated Total Building Energy Cost - Medium Utility Rate .........................................................................41

Table 35: Estimated Normalized Total Building Energy Cost - Medium Utility Rate .........................................................42

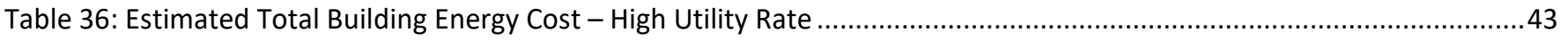

Table 37: Estimated Normalized Total Building Energy Cost - High Utility Rate...............................................................44

Table 38: Estimated Simple Payback and Savings-to-Investment Ratio .................................................................................45

Table 39: Energy Savings of Single-Pane and Double-Pane Secondary Windows with Low SHGC for Climate Zone 1 ...............46

Table 40: Performance Data for Single-Pane and Double-Pane Secondary Window.........................................................51

Table 41: Single-Pane Window Versus Single-Pane Secondary Window Weight Difference ..................................................52

Table 42: Double-Pane Window Versus Double-Pane Secondary Window Weight Difference ................................................52

Table 43: Summary of EnergyPlus Model for Large Office ...............................................................................................61

Table 44: Estimated Energy, Normalized Energy Savings, Payback and SIR of Double-pane Secondary Window for Pre-1980

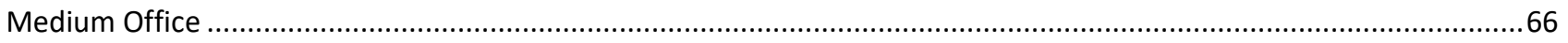

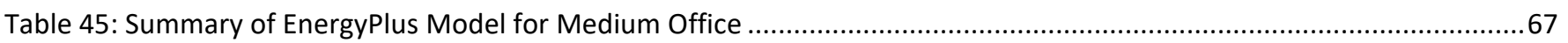




\section{List of Figures}

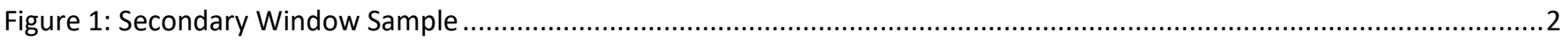

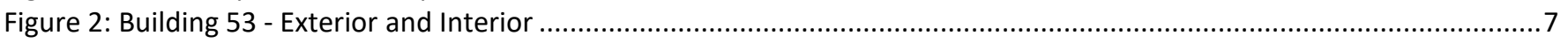

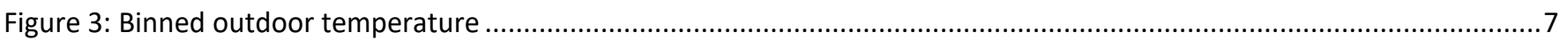

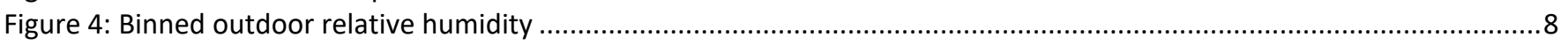

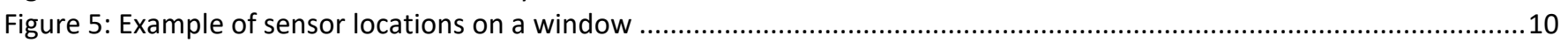

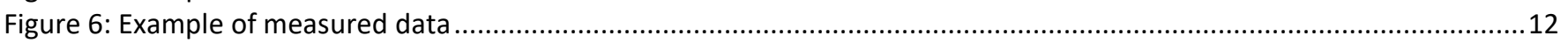

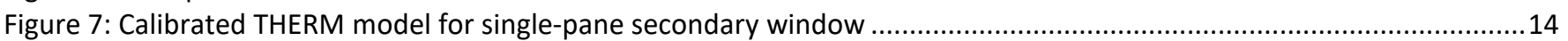

Figure 8: Calibrated THERM model for double-pane secondary window .........................................................................

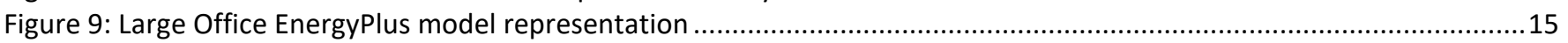

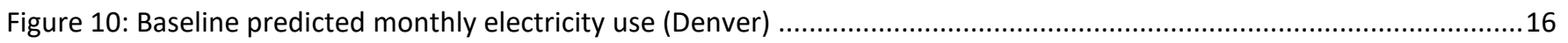

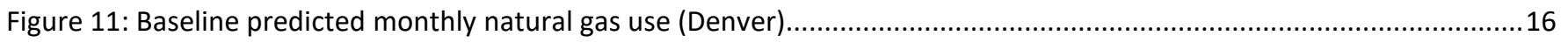

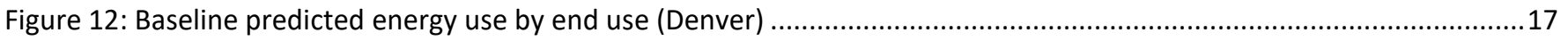

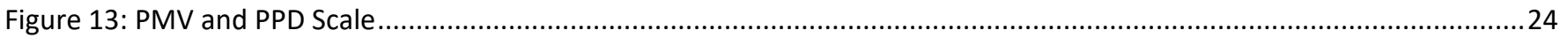

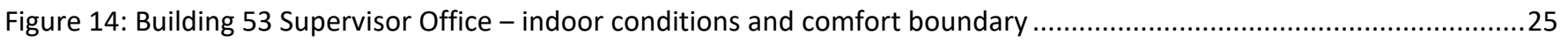

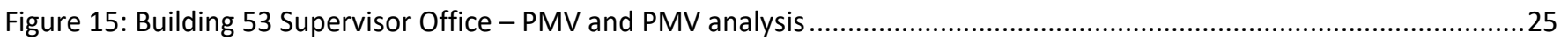

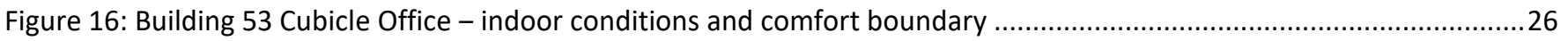

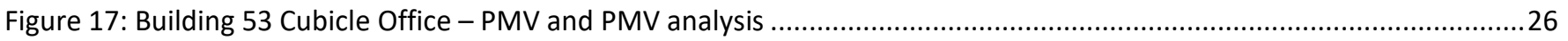

Figure 18: Convective and radiative heat transfer effects on thermal comfort ...............................................................27

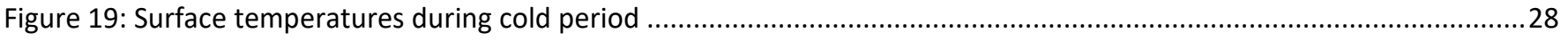

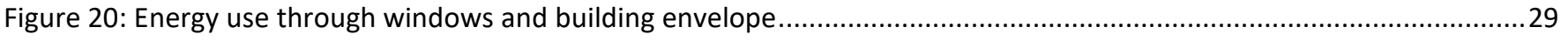

Figure 21: Impact of infiltration on total electric heating energy ............................................................................29

Figure 22: IR image (left) of the two windows outside and the visual photo (right) of the same location.............................58

Figure 23: IR image (left) of the two windows inside and the visual photo (right) of the same location ...............................59

Figure 24: Thermocouples for temperature measurement on glass and frame ...........................................................59

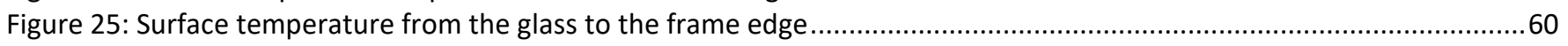




\section{Introduction}

\section{A. PROBLEM STATEMENT}

A window is an opening in a wall, door, or roof that admits light and air into the building and also enables outside viewing. Windows may also enhance the aesthetic appearance of the building. However, windows typically have significantly inferior thermal properties when compared to walls and roofs, and can impact the energy load for a building. This is the case especially in older buildings with poorly insulated windows (e.g., single-pane windows with metal frames).

\section{B. OPPORTUNITY}

High performance, energy-efficient window and glazing systems can significantly reduce energy use in buildings. They have lower heat loss, less air leakage, and warmer window surfaces that improve occupant comfort and minimize condensation. By enabling people to comfortably sit closer to the windows, high performance windows could increase the occupant density. Additionally, they may allow the building to specify smaller, less-costly heating and cooling systems.

This demonstration project assessed the thermal performance, life cycle costs, and deployment potential of two types of window inserts, or "secondary windows," to be used in conjunction with existing, older windows. The secondary windows utilize fiberglass frames to help reduce thermal conductance through the frames.

\section{TECHNOLOGY DESCRIPTION}

A secondary window is a separate window unit consisting of a single- or double-pane glazing within its own frame and is typically installed on the room side of existing windows with a seal around the edges and the windowsill. The secondary window can be quickly and easily installed with existing windows to provide a costeffective and efficient way to improve thermal performance, occupant comfort, and sound reduction-especially for single-pane windows. It uses ultra-thin glass (laminated with safety and performance films) at 1-mm thickness on average and at areas of up to 50 square feet. The secondary window frame is typically a highly insulated framed system, using thermally efficient fiberglass and high R-value polyurethane insulated inserts in the principle chamber in the frame of the product.

The secondary window can be a substantially less expensive alternative to replacing primary windows. In addition, the secondary windows are lightweight and thus suitable for structures that cannot handle additional weight. They are also easily removed to enable window cleaning. Secondary windows significantly improve energy performance over single-pane windows alone. The technology is particularly useful in buildings or areas where planning permission rules do not allow any aesthetic changes whatsoever to the external primary windows (e.g., historic buildings). For this study, two types of secondary windows-singlepane and double-pane-were evaluated. Figure 1 shows a sample of secondary window. 


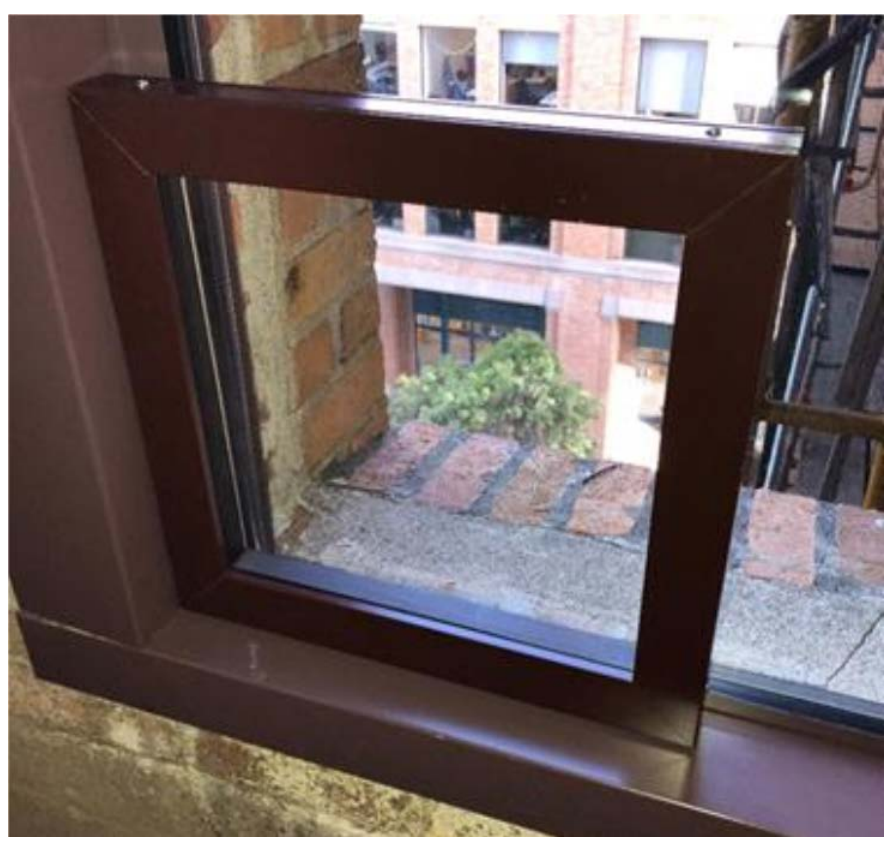

Figure 1: Secondary Window Sample

Credit: Alpen Windows

\section{RESEARCH OPPORTUNITY}

As shown in Table 1, it is estimated that windows are responsible for $39 \%$ of commercial heating energy use and $28 \%$ of commercial cooling energy use, or $34 \%$ of all commercial space conditioning energy use, equivalent to roughly $1.5 \%$ of total U.S. energy consumption (Apte and Arasteh 2006). High insulating windows could significantly reduce the annual U.S. energy use due to windows, but in some cases replacement can be costly; even more so in older buildings where lead paint and/or asbestos must be remediated as part of a window replacement. However, in addition to the energy savings from highly insulating windows, these older buildings may benefit from improved comfort of occupants close to the windows, thereby increasing the occupancy density of the building, and the ability to use smaller, less costly heating and cooling systems when they need to be replaced. 
Table 1: U.S. Annual Commercial Building HVAC and Window-Related Energy Use, Reported in Quadrillion BTUs of Primary (Source) Energy

\begin{tabular}{|c|c|c|c|c|c|}
\hline & $\begin{array}{l}\text { Building } \\
\text { HVAC Energy } \\
\text { Consumption }\end{array}$ & $\begin{array}{l}\text { Window- } \\
\text { Related } \\
\text { Energy } \\
\text { Consumption }\end{array}$ & $\begin{array}{l}\text { Percent of } \\
\text { Building } \\
\text { HVAC Energy } \\
\text { Related to } \\
\text { Windows }\end{array}$ & $\begin{array}{l}\text { Window-Related } \\
\text { Energy } \\
\text { Consumption for } \\
\text { Triple Glazing } \\
\text { Performance }\end{array}$ & $\begin{array}{l}\text { Building } \\
\text { HVAC Energy } \\
\text { Savings for } \\
\text { Triple } \\
\text { Glazing }\end{array}$ \\
\hline Heating & 2.45 & 0.96 & $39 \%$ & 0.25 & $29 \%$ \\
\hline Cooling & 1.90 & 0.52 & $28 \%$ & 0.21 & $16 \%$ \\
\hline Total & 4.35 & 1.48 & $34 \%$ & 0.46 & $23 \%$ \\
\hline
\end{tabular}

Source: Apte and Arasteh (2006)

The U.S. General Services Administration (GSA) pursues cost-effective energy efficiency opportunities for its more than 9,600 facilities. Thus, a variety of highly insulating fenestration products have been evaluated and recommended in the past. However, GSA facilities still have substantial numbers of poorly performing or underperforming windows and the newest technologies still need to be evaluated. Presently, there are a variety of commercially available retrofit and replacement windows that may provide sufficient thermal insulation and reduce air infiltration. ENERGY STAR ${ }^{\mathrm{TM}}$ rated windows have an overall R-value of 3 (R-3). However, even a small increase to R-5 could reduce heat loss through the window by $30 \%-40 \%$. Unfortunately, many facilities are not able to accommodate the size and/or weight increases associated with these more energy-efficient windows. Furthermore, the added costs of the extra glass and associated assemblies may be cost prohibitive.

\section{Evaluation Plan}

\section{A. EVALUATION DESIGN}

\section{STUDY DESIGN AND OBJECTIVES}

As discussed below, several different evaluations assessed the viability of the secondary windows for GSA applications. Some of these assessments were performed with models, while others required onsite evaluations including time series measurements. The primary objectives of the onsite measurement and verification (M\&V) study are:

Objective 1. Verify the high performance benefits of the secondary windows:

a) Thermal performance

b) Heating, ventilating, and air conditioning (HVAC) energy reduction

c) Thermal load (cooling and heating) reduction

d) Comfort improvement

Objective 2. Economic analysis (savings to investment ratio $[S I R]$ and payback)

Objective 3. Evaluate ease of installation and operability 
Objective 4. Assess the deployment potential for other GSA sites and identify screening criteria for future candidate buildings and climate zones.

\section{OBJECTIVE 1: VERIFY THE HIGH PERFORMANCE OF SECONDARY WINDOWS}

The most important M\&V objective is to verify the energy savings. The HVAC energy consumption was evaluated using a simulation modeling approach. Lawrence Berkeley National Laboratory's WINDOW, ${ }^{1}$ a computer program, is used for calculating total window thermal performance indices including U-value, solar heat gain coefficient (SHGC), and visible transmittance (VT). WINDOW can be used to analyze window products made with any combination of glazing layers, gas layers, frames, spacers, and dividers under any environmental conditions. It provides a versatile heat transfer analysis method consistent with the rating procedure developed by the National Fenestration Rating Council (NFRC) that is consistent with the International Organization for Standardization (ISO) 15099 standard. In addition, Lawrence Berkeley National Laboratory's THERM ${ }^{2}$ is used with the WINDOW program to model two-dimensional heat transfer of the window including frame and edge effects. Monitoring data were used for calibrating WINDOW and THERM simulation models. Glass surface temperatures predicted by the THERM computer models were compared to measured surface temperatures using the measured environmental conditions as inputs to the model. The thermal performance characteristics of a singlepane window (baseline) and secondary windows were modeled in the EnergyPlus ${ }^{\mathrm{TM}}{ }^{3}$ simulation modeling tool. EnergyPlus, developed by the U.S. Department of Energy (DOE), is a whole building energy simulation program that is widely used by engineers, architects, and researchers. EnergyPlus requires a detailed description of the building envelope (for thermal and optical properties), internal loads, operating schedules, lighting, HVAC system requirements, and utility rate schedules. The tool is capable of evaluating energy use and energy cost savings that can be achieved by applying energy conservation measures such as improved envelope components, active and passive heating and cooling strategies, lighting system improvements, and HVAC system improvements.

\section{OBJECTIVE 2: ECONOMIC ANALYSIS (PAYBACK)}

Cost effectiveness was evaluated based on energy cost savings, retrofit and installation costs, and operation and maintenance costs compared to the incumbent technology. Overall cost effectiveness was compared to the market claim as a part of this demonstration. The success criterion to qualify the product as cost effective was a payback period of less than 15 years and a savings-to-investment ratio (SIR) greater than 1 . Savings were comprised of estimated energy cost savings and potential savings from HVAC system sizing reduction. Savings from HVAC system capacity reduction were estimated from the heating and cooling capacity reduction multiplied by cost per unit of HVAC heating and cooling capacity. The unit costs of HVAC heating and cooling capacity were derived from data presented within the U.S. Energy Information Administration's (EIA's) Updated Buildings Sector Appliance and Equipment Costs and Efficiencies (EIA 2018). Costs of the technologies used in the analysis came from actual installed costs at the site. For the secondary windows analysis, the first cost of the technology was used.

\section{OBJECTIVE 3: EVALUATE EASE OF INSTALLATION AND OPERABILITY}

Ease of installation is an important metric to be evaluated because the secondary windows are installed in retrofit applications. The time and labor required to install the windows is documented in Section III, Demonstration Results. The criterion for success was that it takes less than a day to install and less than an hour

\footnotetext{
${ }^{1}$ WINDOW, https://windows.lbl.gov/software/window

2 THERM, https://windows.lbl.gov/software/therm

${ }^{3}$ EnergyPlus, https://energyplus.net/
} 
to commission. Operability was evaluated by interviewing operations and maintenance staff and facility operators on site. The criterion for success was that it should not introduce a steep learning curve to install the windows and should not impact regular operations and maintenance.

\section{OBJECTIVE 4: ASSESS THE DEPLOYMENT POTENTIAL FOR OTHER GSA SITES AND IDENTIFY SCREENING CRITERIA FOR FUTURE CANDIDATE BUILDINGS AND CLIMATE ZONES}

One of the main goals of this study was to evaluate suitability of the secondary windows for deployment in GSA buildings across different climate zones. The key metric for determining suitability for deployment was that the simple payback period should be less than 15 years. To evaluate the deployment potential, the DOE Commercial Reference Building Model of a large office was used for the analysis as it represents the majority of the GSA building stock. Analyses were conducted for ten ASHRAE climate zones in which the majority of GSA buildings are located. The energy costs were estimated for three levels of GSA utility rates (low, medium, and high).

Quantitative and qualitative performance objectives for the project are provided in Table 2 and Table 3, respectively.

Table 2: Quantitative Objectives

\begin{tabular}{|c|c|c|}
\hline $\begin{array}{l}\text { Quantitative } \\
\text { Objectives }\end{array}$ & Metrics \& Data & Success Criteria \\
\hline Energy Savings & $\begin{array}{l}\text { HVAC energy consumption } \\
\text { (modeled), kBtu }\end{array}$ & $\begin{array}{l}\text { Energy savings compared to a single-pane window } \\
\text { baseline } \\
10 \% \text { for HVAC energy usage }\end{array}$ \\
\hline $\begin{array}{l}\text { Thermal } \\
\text { Performance } \\
\text { Indices }\end{array}$ & $\begin{array}{l}\text { WINDOW (modeled) } \\
\text { U-values, Btu } / \mathrm{h} \cdot \mathrm{ft}^{2} \cdot{ }^{\circ} \mathrm{F} \\
\text { SHGC, \% } \\
\text { VT, \% }\end{array}$ & $\begin{array}{l}\text { Field installed window within } 20 \% \text { of NFRC-rated } \\
\text { values/manufacturers claims }\end{array}$ \\
\hline $\begin{array}{l}\text { HVAC Peak Loads } \\
\text { Reduction }\end{array}$ & $\begin{array}{l}\text { HVAC cooling loads/ } \\
\text { capacity (modeled), kBtu/hr } \\
\text { HVAC heating loads/ } \\
\text { capacity (modeled), kBtu/hr }\end{array}$ & $\begin{array}{l}\text { HVAC load }{ }^{a} \text { reduction compared to a single-pane } \\
\text { window baseline } \\
10 \% \text { for HVAC cooling and heating loads }\end{array}$ \\
\hline $\begin{array}{l}\text { Cost- } \\
\text { Effectiveness }\end{array}$ & $\begin{array}{l}\text { Simple payback period, year } \\
\text { SIR, unitless }\end{array}$ & $\begin{array}{l}<15 \text {-year payback } \\
>1 \text { SIR }\end{array}$ \\
\hline Thermal Comfort & $\begin{array}{l}\text { Space temperature, }{ }^{\circ} \mathrm{F} \text { and } \\
\text { relative humidity, } \% \\
\text { Room side glass surface } \\
\text { temperature, }{ }^{\circ} \mathrm{F} \\
\text { Wall temperature, }{ }^{\circ} \mathrm{F}\end{array}$ & $\begin{array}{l}\text { Space temperature and relative humidity are within } \\
\text { range of occupant thermal comfort defined by } \\
\text { ASHRAE Standard 55-2013 }\end{array}$ \\
\hline
\end{tabular}




\begin{tabular}{l|l|l}
\multicolumn{1}{c|}{$\begin{array}{c}\text { Quantitative } \\
\text { Objectives }\end{array}$} & \multicolumn{1}{|c|}{ Metrics \& Data } & \multicolumn{1}{c}{ Success Criteria } \\
Condensation & $\begin{array}{l}\text { Room-side glass surface } \\
\text { temperature, }{ }^{\circ} \mathrm{F}\end{array}$ & \\
& $\begin{array}{l}\text { Relative humidity, \% } \\
\text { Calculated Condensation } \\
\text { Resistance (CR) rating, 0- } \\
100\end{array}$ & CR rating greater than 50 \\
\hline
\end{tabular}

${ }^{a}$ HVAC load or capacity for potential HVAC sizing reduction.

Table 2: Qualitative Objectives

\begin{tabular}{l|l|l}
$\begin{array}{l}\text { Qualitative } \\
\text { Objectives }\end{array}$ & \multicolumn{1}{|c|}{ Metrics \& Data } & \multicolumn{1}{c}{ Success Criteria } \\
$\begin{array}{l}\text { Ease of } \\
\text { Installation }\end{array}$ & $\begin{array}{l}\text { Thterview with installer } \\
\text { configure }\end{array}$ & $<1$ day to install \\
\hline $\begin{array}{l}\text { Thermal } \\
\text { Comfort }\end{array}$ & Tenant satisfaction survey & $\begin{array}{l}\text { Improvement in tenant satisfaction with thermal } \\
\text { conditions }\end{array}$ \\
\hline
\end{tabular}

\section{B. INSTRUMENTATION PLAN}

\section{DESCRIPTION OF DEMONSTRATION SITE}

GSA selected Building 53 at the Denver Federal Center in Colorado as a demonstration site for testing the secondary windows. The buildings represent a typical GSA office building which constitutes the majority of the GSA building stock. Figure 2 shows the exterior and interior of Building 53 section, where the secondary window testing was conducted.

Building 53 is a 164,000 square-foot, two-story building located on Fifth Street. The building consists largely of office spaces, as well as some light industrial, laboratory, and food service spaces. It also includes small sections of warehouse and conference/training space. The building area where the secondary windows were evaluated is a single-story section that consists of cubicle offices, a supervisor's closed office, and a conference room. The baseline single-pane window has an original metal frame and dividers. The window is tinted with a fairly dark film. For this study, four double-pane secondary windows were installed at the supervisor's closed office and four single-pane secondary windows were installed at the cubicle offices. The windows are exposed to the direct sunlight from morning to early afternoon. Each window also has a manually operated interior white woven roller shade. The shades were set in a fully opened position during off hours and weekends. Only periods during which the shades were raised were used for comparing measured data to modeled data. 

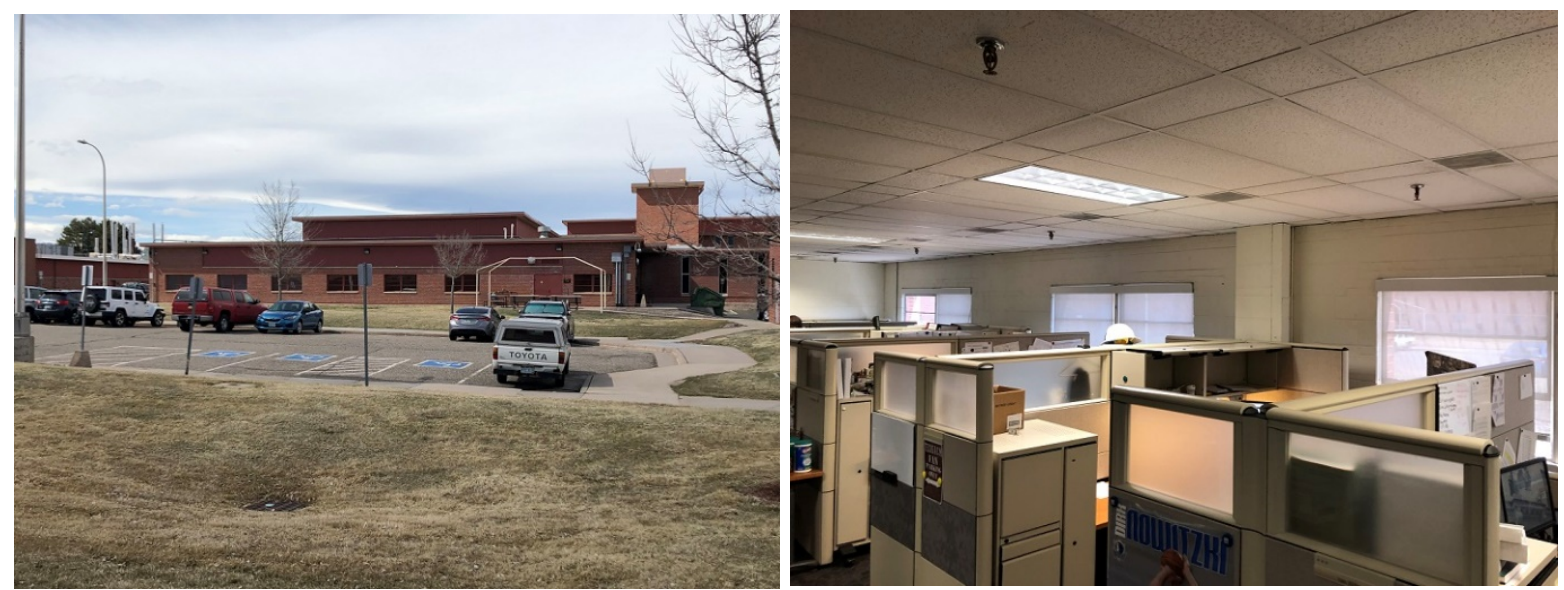

Figure 2: Building 53 - Exterior and Interior

(Credit: Kosol Kiatreungwattana)

\section{CLIMATE CHARACTERISTICS}

Denver is a heating-dominated climate. Figure 3 and Figure 4 show the binned outdoor temperature and the binned outdoor relative humidity from the Typical Meteorological Year (TMY) 3 weather data for Denver International Airport. The outdoor temperature is less than $80^{\circ} \mathrm{F}$ for more than $80 \%$ of the total hours annually.

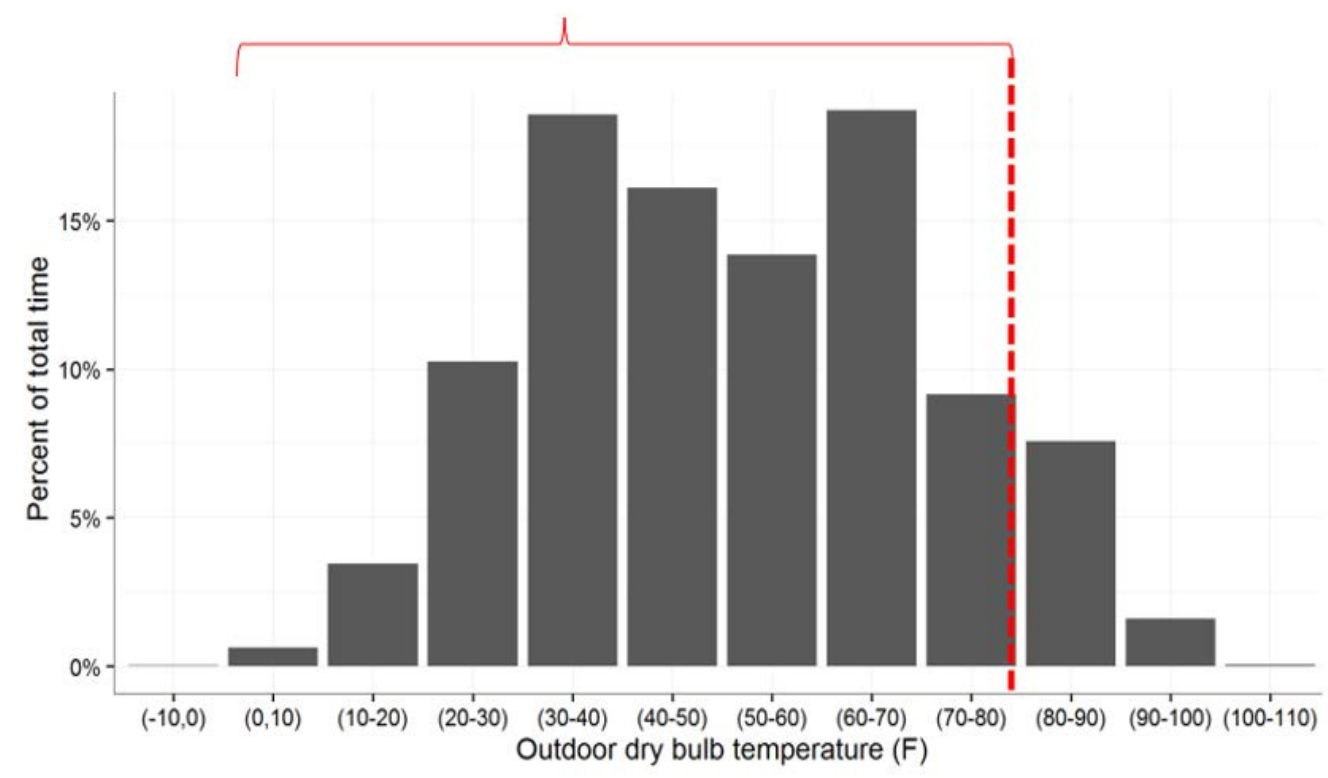

Figure 3: Binned outdoor temperature 


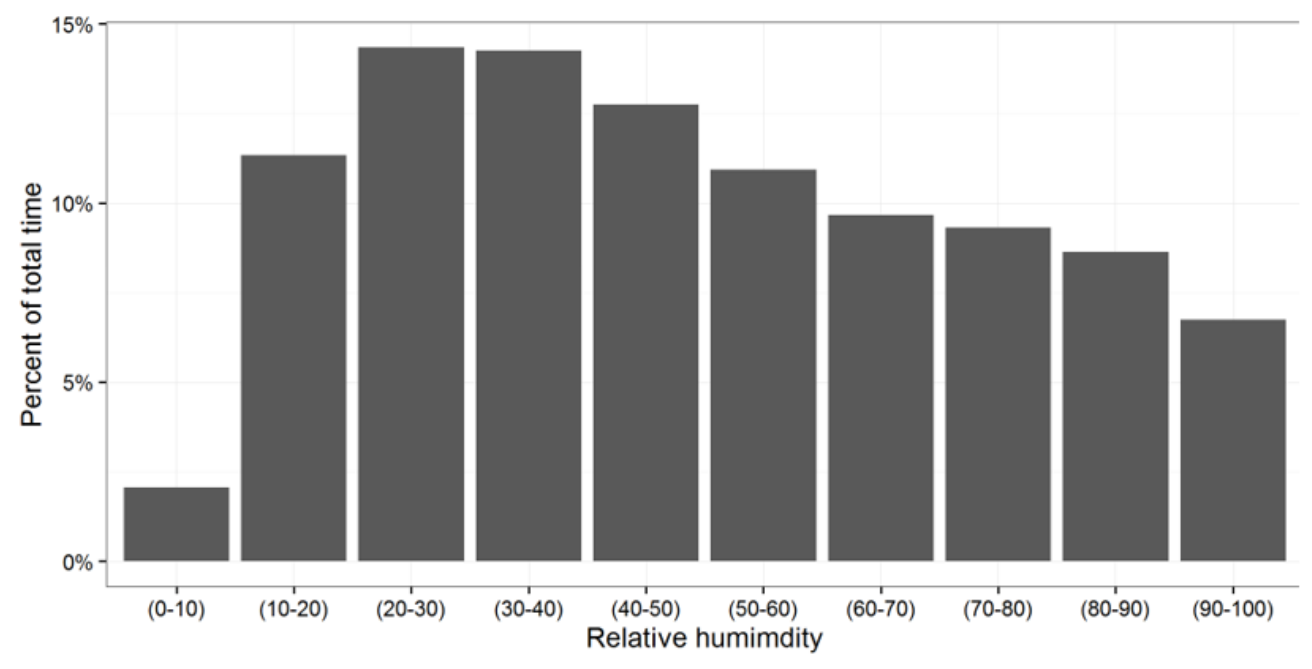

Figure 4: Binned outdoor relative humidity

\section{MONITORING AND INSTRUMENTATION}

The National Renewable Energy Laboratory (NREL) team installed a data acquisition system consisting of data loggers, temperature sensors, and wireless temperature and humidity sensors at the baseline single-pane window and secondary windows. Space conditions were monitored for thermal comfort analysis. All monitoring points and instrumentation are described in Table 4. Monitoring data was collected remotely at NREL's office in Golden, Colorado. Information was sent via a modem connection to the data loggers. Figure 5 shows an example of sensor locations on a window. 
Table 4: Monitoring Points and Instrumentation

\begin{tabular}{|c|c|c|c|}
\hline $\begin{array}{l}\text { Monitoring } \\
\text { Point }\end{array}$ & $\begin{array}{l}\text { Logging } \\
\text { Equipment } \\
\text { Description }\end{array}$ & Location & Notes \\
\hline Window & Thermocouples & $\begin{array}{l}\text { Two glazings (outer and inner) } \\
\text { 1. Center of glass, inside and } \\
\text { outside surfaces (two } \\
\text { thermocouples total) } \\
\text { 2. Two inches from glass } \\
\text { edge, inside and outside } \\
\text { surfaces (two } \\
\text { thermocouples total) } \\
\text { One inch from glass edge, } \\
\text { inside and outside surfaces } \\
\text { (2 thermocouples total) } \\
\text { Frame, inside and outside } \\
\text { surfaces (two } \\
\text { thermocouples total) } \\
\text { 5. Wall between windows }\end{array}$ & $\begin{array}{l}\text { Up to } 50 \text { thermocouples total for Building } \\
53 \\
\text { Eight thermocouples per window (note } \\
\text { more were used for the existing divided } \\
\text { single-pane windows to measure } \\
\text { differences between each section of the } \\
\text { window) }\end{array}$ \\
\hline $\begin{array}{l}\text { Space } \\
\text { conditions }\end{array}$ & $\begin{array}{l}\text { Temperature sensors } \\
\text { Humidity sensors }\end{array}$ & $\begin{array}{l}\text { Work-plane height } \\
\text { Room temperature } \\
\text { Room relative humidity }\end{array}$ & $\begin{array}{l}\text { Three temperature and humidity sensors } \\
\text { for Building } 53\end{array}$ \\
\hline $\begin{array}{l}\text { Ambient } \\
\text { conditions }\end{array}$ & Weather station & $\begin{array}{l}\text { Temperature } \\
\text { Humidity } \\
\text { Wind speed }\end{array}$ & $\begin{array}{l}\text { Temperature and humidity were } \\
\text { measured on-site. Wind speed data from } \\
\text { the weather station at NREL Solar } \\
\text { Radiation Research Laboratory (SRRL) was } \\
\text { used. The NREL SRRL is approximately five } \\
\text { miles from the Denver Federal Center. }\end{array}$ \\
\hline Comfort & Comfort survey & Employees selected by GSA & Up to six occupant surveys for Building 53 \\
\hline $\begin{array}{l}\text { Surface } \\
\text { temperature }\end{array}$ & $\begin{array}{l}\text { Thermal imaging } \\
\text { camera }\end{array}$ & Window, frame, and wall & $\begin{array}{l}\text { Conduct multiple thermal imaging studies } \\
\text { in summer and winter to support window } \\
\text { thermal performance indices calculation }\end{array}$ \\
\hline
\end{tabular}

The schedule for monitoring and evaluating the technologies is summarized in Table 5.

- Monitoring equipment was installed for the baseline single-pane window in the conference room at Building 53 on September 5-6, 2019. The monitoring data were collected from September 6, 2019 to June 30, 2020.

- Double-pane secondary windows and monitoring equipment were installed on September 4-6, 2019. The monitoring data were collected from September 6, 2019 to June 30, 2020. 
- Single-pane secondary windows and monitoring equipment were installed on December 4, 2019. The monitoring data were collected from December 4, 2019 to June 30, 2020.

Table 5: Monitoring and Instrumentation Schedules

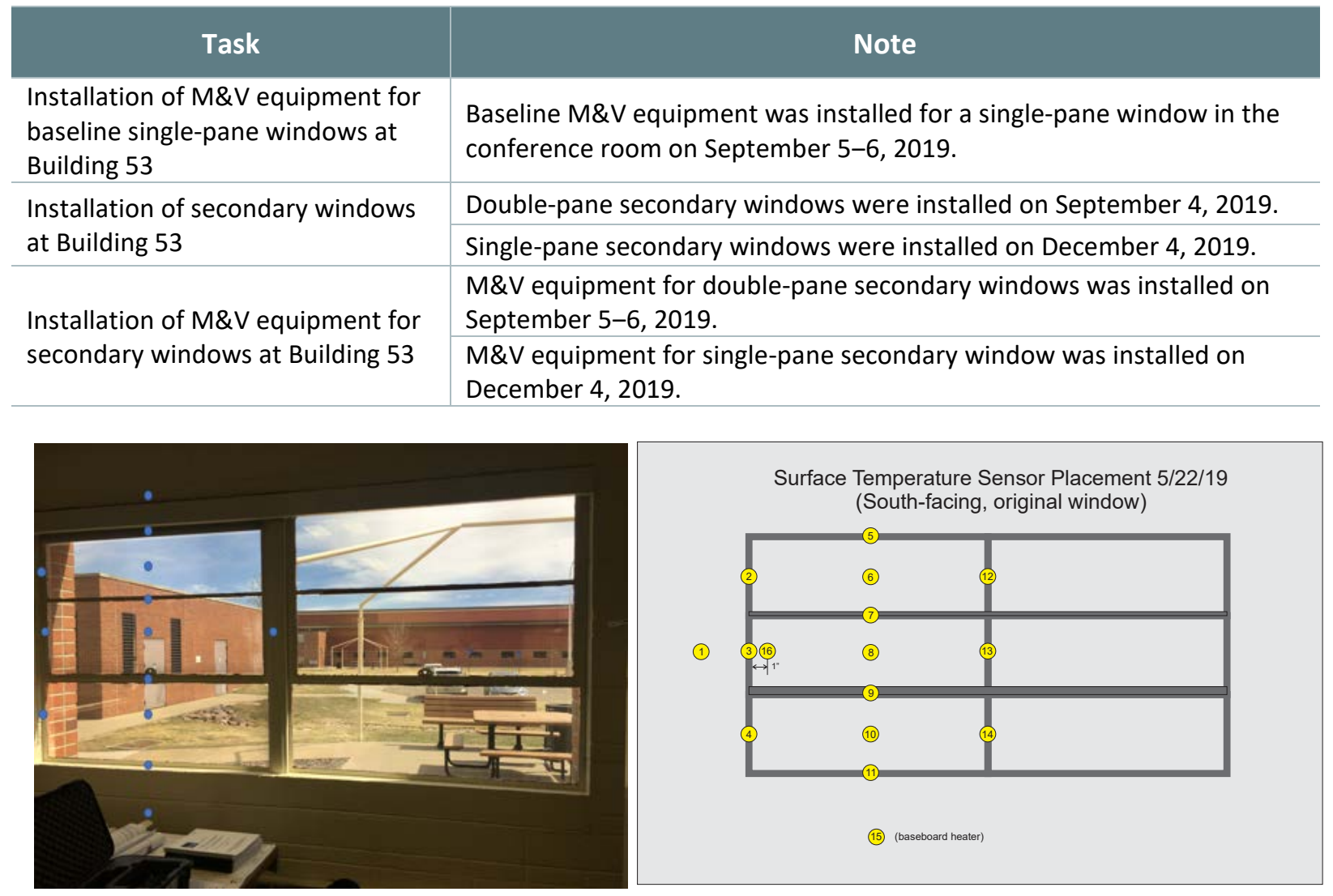

Figure 5: Example of sensor locations on a window

\section{Demonstration Results}

\section{A. MONITORING ACTIVITIES}

Measured temperature responses were taken of the high-performance and secondary window components at Building 53 for comparison to those predicted by the detailed computer models THERM and WINDOW. Driving functions, which were used as inputs to the models, and the responses of certain points in the window systems were measured. It should be noted that we did not attempt to measure the solar-gain-related behavior of the windows - only the conduction and convection behavior was measured. It was assumed that the transmittance and spectral properties of the glazing materials were already well characterized by laboratory tests. We were also not attempting to measure or model the thermal capacity behavior of the window components as the THERM and WINDOW programs assume steady-state conditions. With these parameters in mind, the following measurements were made: 
1. Driving functions

a. Outdoor dry-bulb temperature

b. Indoor dry-bulb temperature approximately $30 \mathrm{~cm}$ from the window

2. Responses

a. Window frame temperatures, inside and outside

b. Glazing temperatures $2.5 \mathrm{~cm}$ ( 1 inch) from the frame, inside and outside

c. Glazing temperatures at the center of the glazing, inside and outside.

All temperature measurements were taken using 30-gauge thermocouples affixed to the surfaces using Kapton tape. Temperatures were measured continuously and stored as 1-minute, 15-minute, 60-minute, and daily averages. All data were stored on the data loggers themselves, a personal computer, and on a cloud-based server. Our approach was to search for 15-minute-averaged points within the data that met the following criteria to ensure that the data represented near-steady-state conditions in which the temperatures are nearly constant, and the wind is minimal for a period of time.

1. Time is after sunset and before sunrise to eliminate impacts of direct solar gain to the window

2. Wind speed has been near-zero for $\mathbf{3 0}$ minutes, to eliminate the impacts of convection heat transfer to the window

3. Standard deviation of wind speed over the last 30 minutes is at a minimum

4. Standard deviation of outdoor dry-bulb temperature over the last hour is at a minimum

5. Standard deviation of indoor dry-bulb temperature near the window over the last hour is at a minimum

6. Standard deviation of outdoor center-of-glass temperature over the last hour is at a minimum

7. Standard deviation of indoor center-of-glass temperature over the last hour is at a minimum.

Two sets of data that met the steady-state criteria for each of the three windows under study were used for THERM and WINDOW modeling and calibration. Figure 6 shows an example of a data set. Filtered data (black dot) that met the steady-state criteria were used to support THERM and WINDOW modeling. 


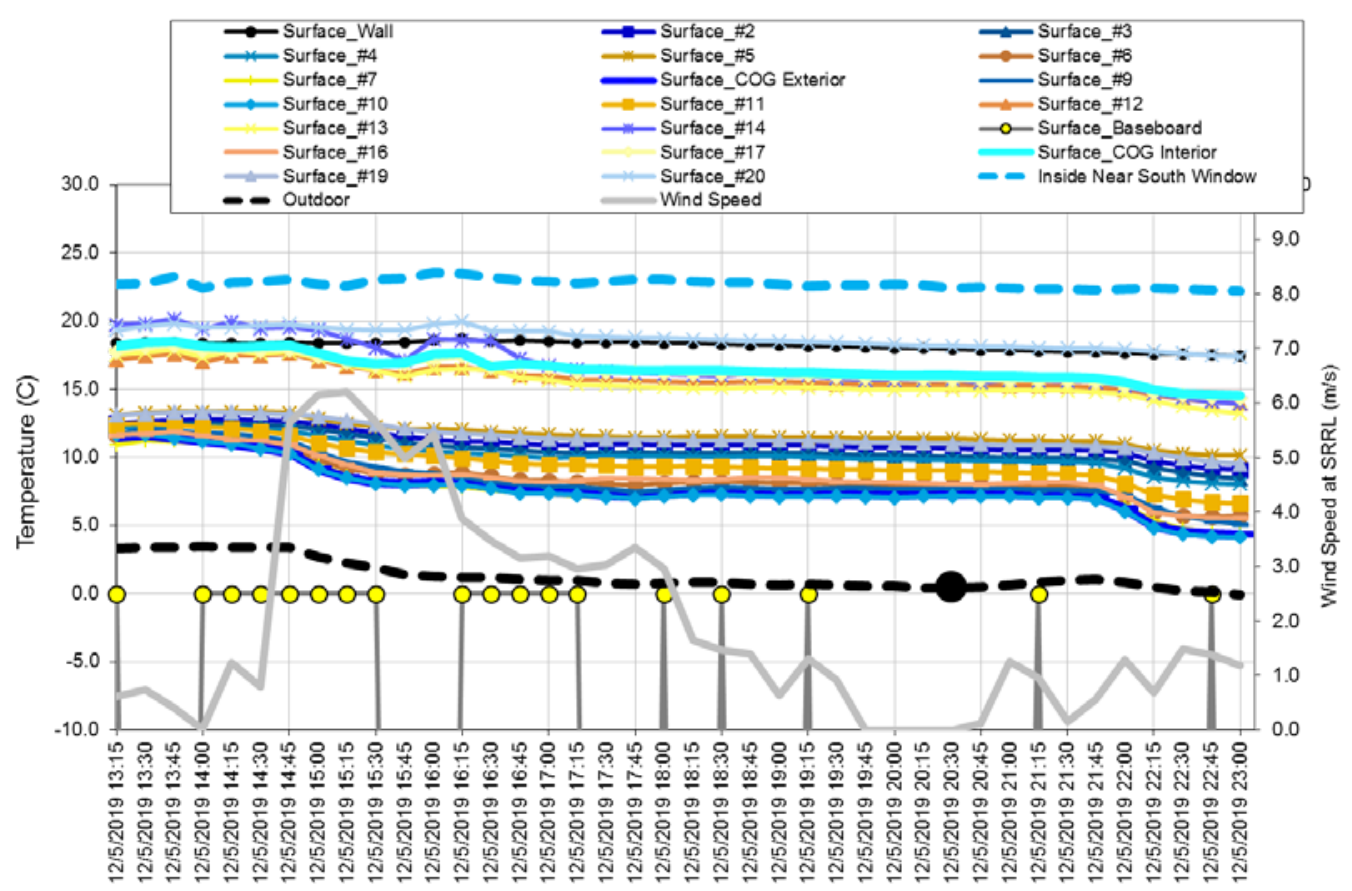

Figure 6: Example of measured data

In addition to the above measurements, several infrared (IR) photos of the temperature gradient near the edge of the glass were taken on a few occasions in the early morning before the sun hit the glass. These photos were analyzed to show a more detailed set of temperatures along the steep gradient than can be inferred from the few point measurements that were made continuously.

\section{MONITORING ISSUES AND FINDINGS}

Issues and findings related to monitoring included the following.

1. Wind speed: Calculating actual forced-convection heat transfer coefficients based on wind speed is notoriously difficult, but calculating natural convection based on surface and air temperatures under zero wind speed is much more reliable. Wind data was taken from the SRRL. The near-zero wind speed for a period of time was used to assume steady-state conditions. It was assumed that if the wind speed at SRRL was zero, it was likely to be zero at the Denver Federal Center.

2. Infrared energy exchange: Radiant temperature with which the window system exchanges heat via IR radiation was not measured. There are two radiant environments, one outdoors and one indoors. The indoor environment can reasonably be assumed to be equal to the indoor dry-bulb temperature, as nearly all the view factor of the inside of the windows is to interior walls. The outdoor environment temperature is not as easily determined. The window has significant view factors to the adjacent buildings, to the ground, and to the sky. Sky temperature is available from SRRL, but the temperatures of the adjacent buildings and ground were unknown. The building and ground temperatures were estimated for boundary conditions in the THERM model.

3. Window coverings: All of the windows studied have operable window coverings that the occupants of the offices use regularly to reduce glare in the office space. When the window covering is down, even part-way, 
the heat transfer mechanisms affecting the window are changed significantly. Therefore, only data during periods when the window covering was disabled were compared to the THERM and WINDOW models. The building manager ensured the blinds were fully opened at the end of each day and weekend in Building 53.

4. Baseboard heaters: At Building 53, there are baseboard heaters actively running underneath all of the windows. This was a concern because it could directly affect the bulk air temperature near the inside of the window, which is a driving function of the models. Temperature sensors were installed for the baseboard heaters to monitor when the heaters are running. The results showed that the baseboard heaters were running almost all of the time during the night. However, the bulk air temperature near the window and this temperature remained steady most of the time, allowing it to meet the steady-state criteria described above.

\section{THERM AND WINDOW MODELING}

THERM and WINDOW models were created for the baseline single-pane window and secondary windows. Measured glass and frame surface temperatures were used for calibration and comparison with predicted surface temperatures.

The baseline single-pane window has metal dividers that do not represent a typical single-pane window. Therefore, a model of the baseline window with metal dividers was created for a comparison and calibration with monitoring data, but a model for the baseline window without dividers was used for further analysis in EnergyPlus building energy simulation modeling.

Table 6 presents the WINDOW results of calculated window system performance indices.

THERM and WINDOW models were created for the cases presented below.

1. Baseline single-pane window

- With metal dividers

- Without metal dividers

2. Single-pane secondary window

- Stand-alone (for comparison to claimed thermal performance indices)

- Integrated with baseline single-pane window with metal dividers for calibration

- Integrated with baseline single-pane window without dividers for further EnergyPlus analysis

3. Double-pane secondary window

- Stand-alone (for comparison to claimed thermal performance indices)

- Integrated with baseline single-pane window with metal dividers for calibration

- Integrated with baseline single-pane window without dividers for further EnergyPlus analysis.

\section{THERM and WINDOW Model Results and Findings}

THERM and WINDOW model results and findings include the following:

- Calibrated THERM models accurately predict measured surface temperatures of the glass and frame of the windows

- The performance indices of single-pane windows with and without metal dividers are similar

- Results of the single-pane windows without dividers were used as a baseline for other analyses

- U-value of the double-pane secondary window is significantly better than that of the single-pane secondary window 
- Double-pane secondary window has approximately half the U-value of the single-pane secondary window.

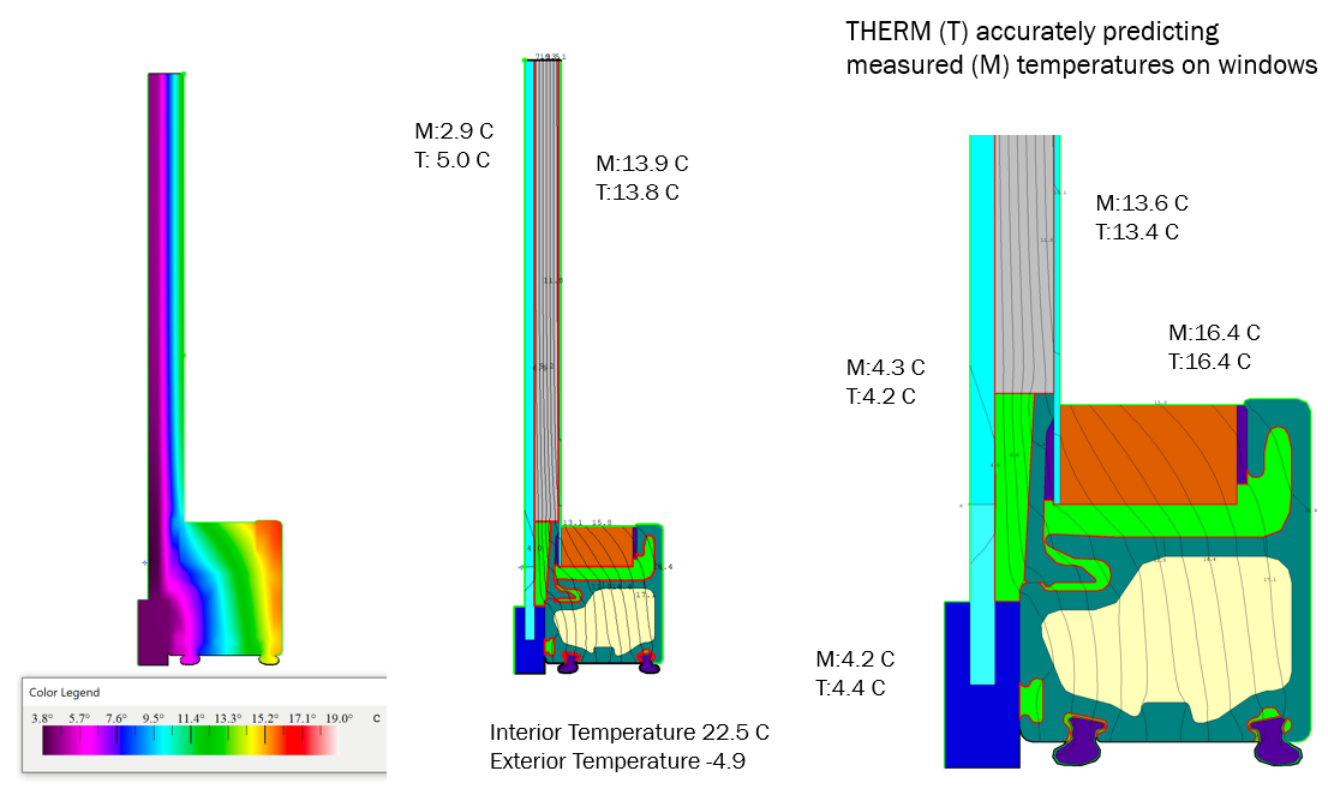

Figure 7: Calibrated THERM model for single-pane secondary window

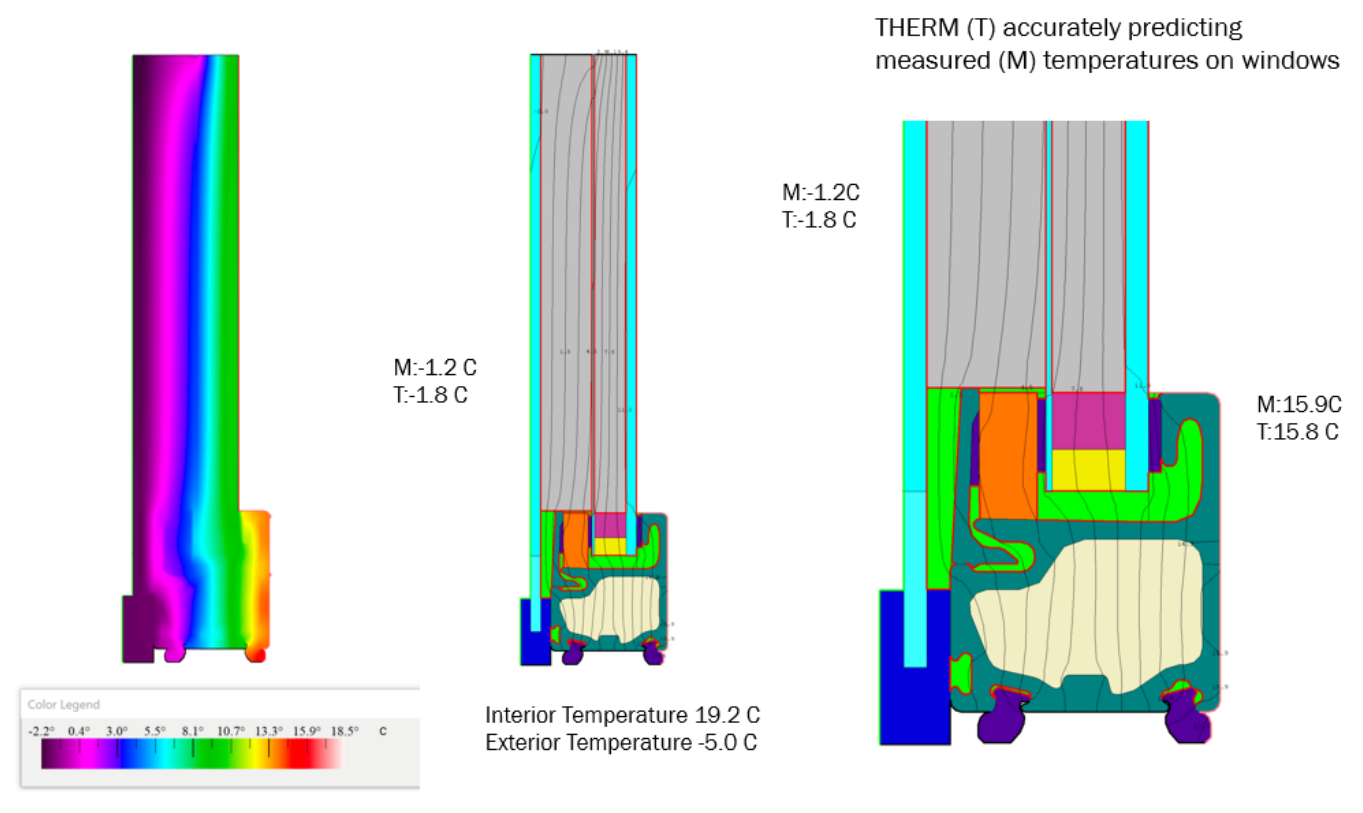

Figure 8: Calibrated THERM model for double-pane secondary window 
Table 6: Window Performance Indices Calculated Using WINDOW

\begin{tabular}{l|c|c|c|c|c} 
& \multicolumn{2}{|c|}{ U-Value } & $\begin{array}{c}\text { Solar Heat } \\
\text { Gain } \\
\text { Coefficient }\end{array}$ & $\begin{array}{c}\text { Visible } \\
\text { Transmittance }\end{array}$ & $\begin{array}{c}\text { Condensation } \\
\text { Rating }\end{array}$ \\
\cline { 2 - 5 } & $\left(\mathbf{W} / \mathrm{m}^{2} \cdot \mathrm{K}\right)$ & $\mathrm{Btu} /\left(\mathbf{h} \cdot \mathrm{ft}^{2} \cdot \mathrm{F}\right)$ & 0.81 & 12 \\
\hline $\begin{array}{l}\text { Existing single-pane } \\
\text { window }\end{array}$ & 6.799 & 1.197 & 0.84 & 14 \\
\hline $\begin{array}{l}\text { Existing single-pane } \\
\text { window with metal } \\
\text { dividers }\end{array}$ & 7.475 & 1.316 & 0.79 & 0.82 & 44 \\
\hline $\begin{array}{l}\text { Single-pane } \\
\text { secondary window } \\
\text { with baselined } \\
\text { single- } \\
\text { pane window }\end{array}$ & 3.019 & 0.532 & 0.70 & 0.73 & 46 \\
\hline $\begin{array}{l}\text { Double-pane } \\
\text { secondary window } \\
\text { with baselined } \\
\text { single- } \\
\text { pane window }\end{array}$ & 1.320 & 0.232 & 0.42 & 0.58 & \\
\hline
\end{tabular}

\section{ENERGYPLUS MODELING}

DOE's Commercial Reference Building Models for a large-sized office building constructed from 1980-2004, Denver TMY3 weather data, and GSA medium utility rates were used for the whole building simulation analysis to support the evaluation of the technologies at the Denver Federal Center. A graphical representation of the building energy model developed in EnergyPlus is shown in Figure 9. Details and characteristics of the large office building model can be found in Appendix E. Figure 10 and Figure 11 graphically display the predicted monthly electricity and natural gas use. Figure 12 presents the EnergyPlus output for the baseline energy model by end use. As shown, lighting is the largest electrical energy consumer followed by equipment, fan, and cooling.
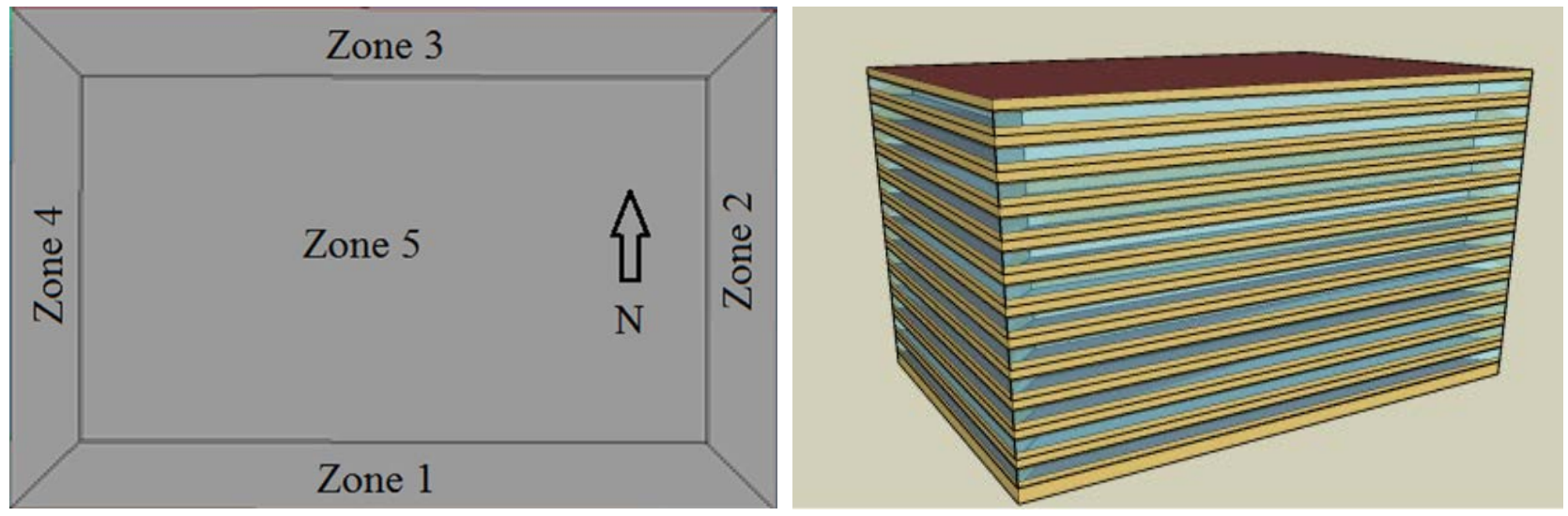

Figure 9: Large Office EnergyPlus model representation 
Table 7: EnergyPlus Results for Large Office Baseline

\begin{tabular}{l|c}
\multicolumn{1}{c|}{ Building Metric } & Large Office \\
\hline Total building area & $498,588 \mathrm{ft}^{2}$ \\
\hline Weather file & $\begin{array}{c}\text { Climate Zone } 5 \mathrm{~B}, \text { Denver } \\
\text { Colorado }\end{array}$ \\
\hline Total site energy & $37,585,328 \mathrm{kBtu} / \mathrm{yr}$ \\
\hline Site energy use intensity & $75.38 \mathrm{kBtu} / \mathrm{ft}^{2}$ \\
\hline Total energy cost & $\$ 995,932 / \mathrm{yr}$ \\
\hline Normalized energy cost & $\$ 2.00 / \mathrm{ft}^{2} / \mathrm{yr}$ \\
\hline
\end{tabular}

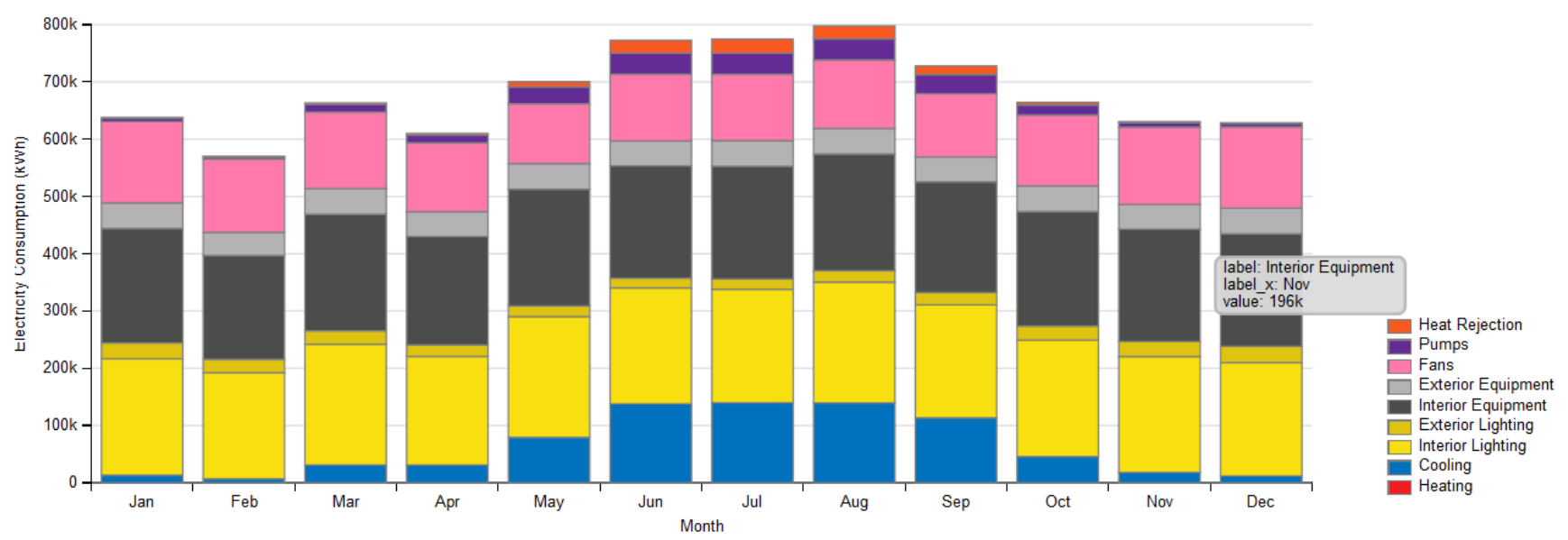

Figure 10: Baseline predicted monthly electricity use (Denver)

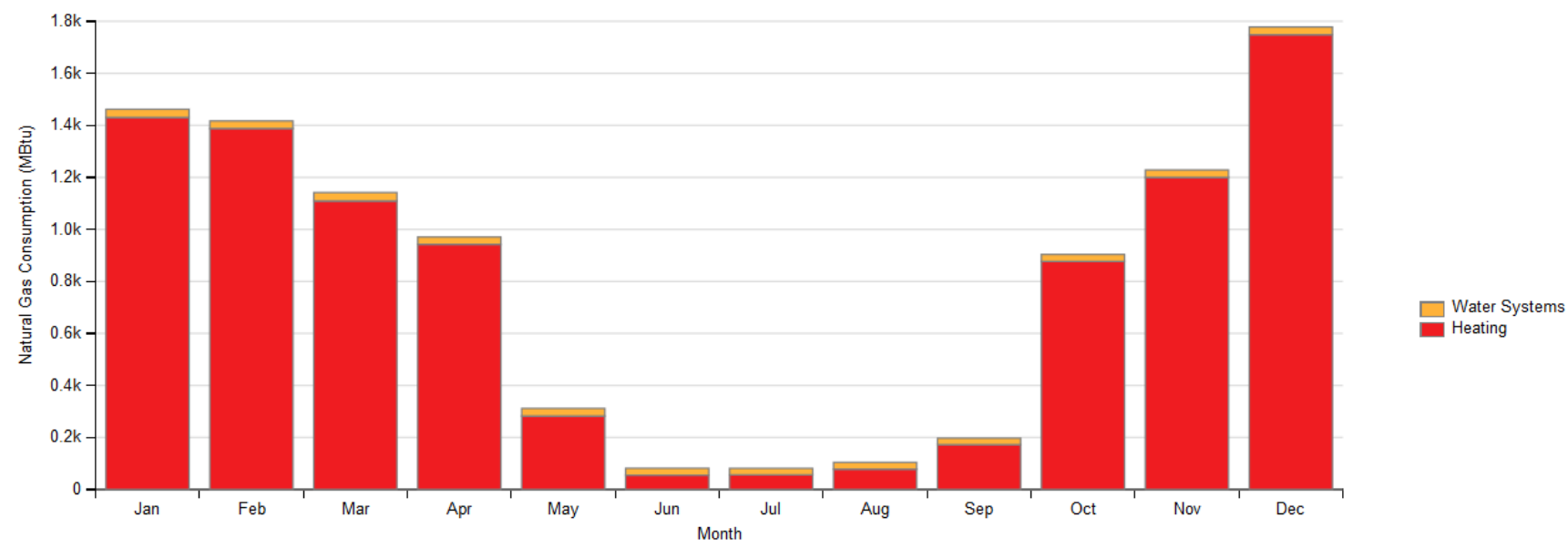

Figure 11: Baseline predicted monthly natural gas use (Denver) 

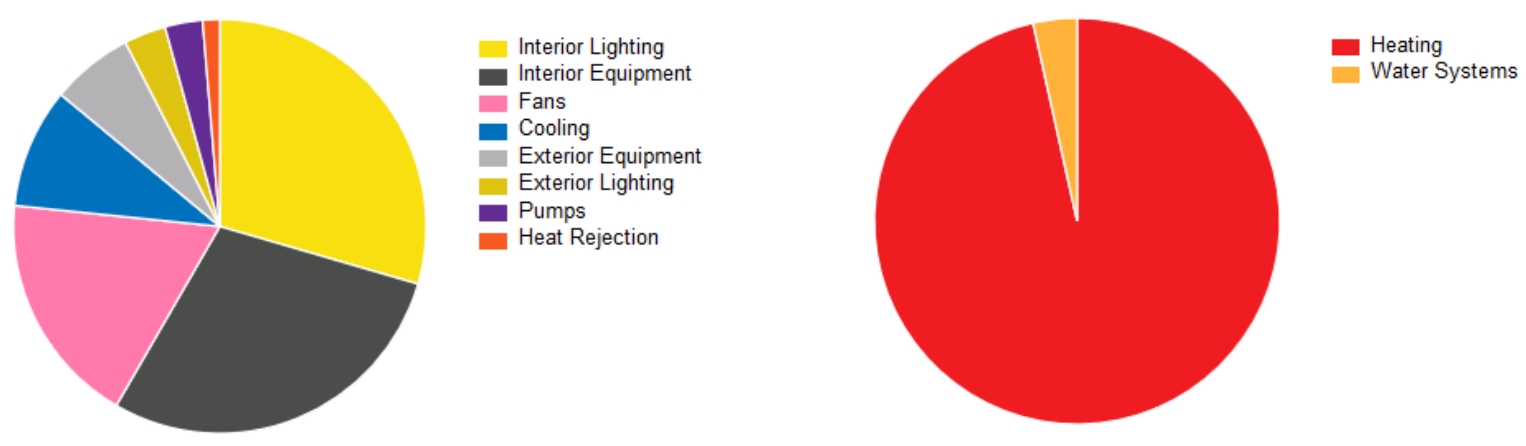

Figure 12: Baseline predicted energy use by end use (Denver)

\section{B. QUANTITATIVE RESULTS}

\section{HEATING, VENTILATING, AND AIR CONDITIONING ENERGY SAVINGS}

Quantitative results relative to the objectives set out at the start of the evaluation are discussed below. Energy savings were estimated from the EnergyPlus simulation models. The majority of energy savings are from heating and cooling energy reduction. The success criterion was a minimum $10 \%$ reduction in heating and cooling energy for the secondary windows.

The success criteria were met. Cooling energy reduction is expected to be $9 \%$ to $22 \%$, heating energy reduction is expected to be $28 \%$ to $52 \%$, and fan energy reduction is expected to be $12 \%$ to $28 \%$. The total HVAC energy reduction is expected to be $20 \%$ to $40 \%$. The secondary windows provide greater energy savings due to improved thermal performance. Details of the HVAC energy saving criteria and results can be found in Table 8 and Table 9.

Table 8: Quantitative Objectives and Results - Energy Savings

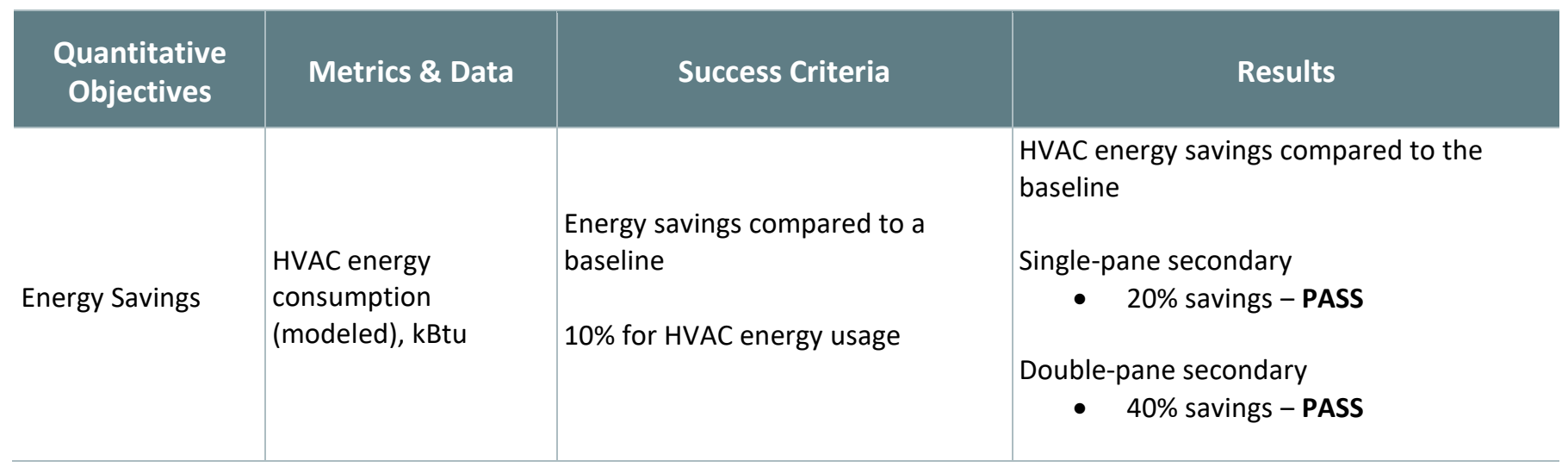


Table 9: Estimated Annual HVAC Energy Savings

\begin{tabular}{l|c|c|c} 
& $\begin{array}{l}\text { Single- } \\
\text { Pane } \\
\text { Baseline }\end{array}$ & $\begin{array}{l}\text { Single- } \\
\text { Pane } \\
\text { Secondary }\end{array}$ & $\begin{array}{l}\text { Double- } \\
\text { Pane } \\
\text { Secondary }\end{array}$ \\
\hline Cooling Energy (MBtu) & 2,619 & 2,394 & 2,052 \\
\hline Heating Energy (MBtu) & 9,339 & 6,706 & 4,497 \\
\hline Fan Energy (MBtu) & 5,091 & 4,489 & 3,667 \\
\hline Total HVAC Energy (MBtu) & 17,049 & 13,589 & 10,216 \\
\hline Reduction in Cooling Energy (\%) & N/A & $9 \%$ & $22 \%$ \\
\hline Reduction in Heating Energy (\%) & N/A & $28 \%$ & $52 \%$ \\
\hline Reduction in Fan Energy (\%) & N/A & $12 \%$ & $28 \%$ \\
\hline Reduction in Total HVAC Energy (\%) & N/A & $20 \%$ & $40 \%$ \\
\hline
\end{tabular}

\section{THERMAL PERFORMANCE INDICES}

Various thermal performance indices were used as criteria to compare the calculated values from the WINDOW program to manufacturers' claims. The thermal performance indices of U-value, SHGC, and VT are widely used as ratings values, similar to the gas mileage rating of an automobile or the energy ratings of a refrigerator. The thermal performance indices for the secondary window are for the theoretical case in which the secondary window is used as a stand-alone window, although this type of installation is not recommended by the manufacturer. The secondary windows are specifically designed to be integrated with an existing window. The calculated thermal performance indices of the stand-alone windows were used to compare to the NFRC-rated values. The success criteria were that the calculated values should be within $20 \%$ of the manufacturers' claimed values. However, any performance indices that exceed the $20 \%$ range and would indicate greater energy savings are considered to meet the criteria. All performance indices are within the claimed values. The validated U-value of the double-pane secondary window is $30 \%$ lower than the claimed value and considered to meet the criteria as it exceeded the thermal performance described above. Details of the thermal performance indices criteria and results are shown in Table 10 and Table 11.

\section{Table 10. Quantitative Objectives and Results - Thermal Performance Indices}

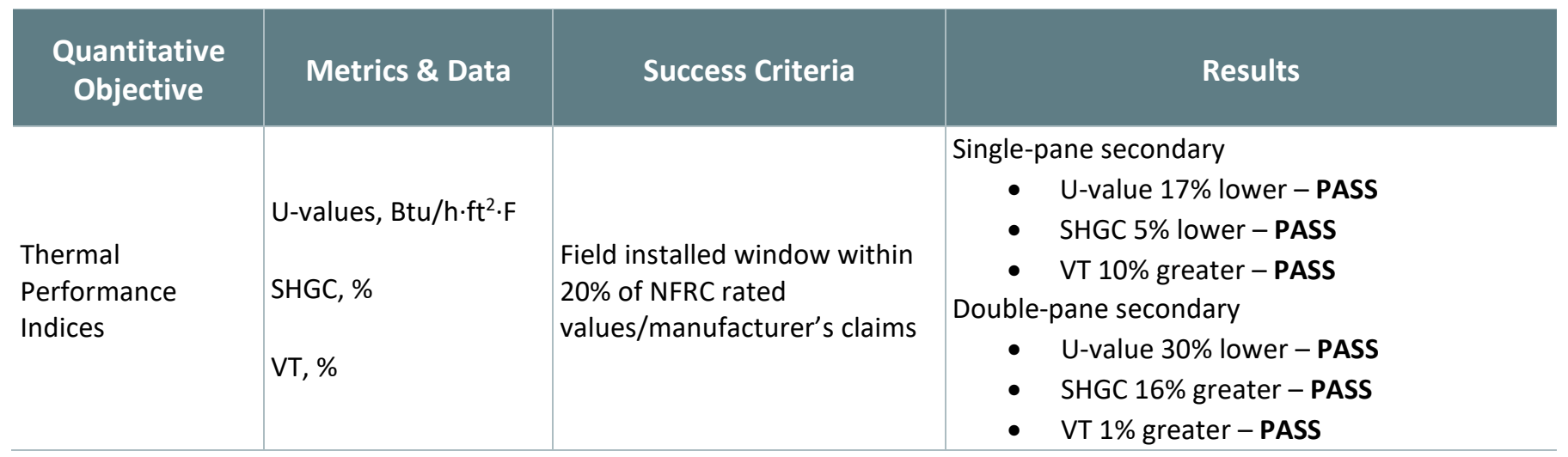




\section{Table 13: Quantitative Objectives and Results - HVAC Capacity Reduction}

\begin{tabular}{|c|c|c|c|}
\hline $\begin{array}{c}\text { Quantitative } \\
\text { Objective }\end{array}$ & Metrics \& Data & Success Criteria & Results \\
\hline $\begin{array}{l}\text { HVAC Capacity } \\
\text { Reduction }\end{array}$ & $\begin{array}{l}\text { HVAC cooling capacity } \\
\text { (modeled), kBtu/hr } \\
\text { HVAC heating capacity } \\
\text { (modeled), kBtu/hr }\end{array}$ & $\begin{array}{l}\text { HVAC capacity }{ }^{\text {a }} \text { reduction } \\
\text { compared to a baseline } \\
\begin{array}{l}10 \% \text { for HVAC cooling and } \\
\text { heating loads }\end{array}\end{array}$ & $\begin{array}{l}\text { Single-pane secondary window } \\
\text { - } 10 \% \text { for HVAC heating capacity - PASS } \\
\text { - } 8 \% \text { for HVAC cooling capacity - DID NOT PASS } \\
\text { Double-pane secondary window } \\
\text { - } 19 \% \text { for HVAC heating capacity - PASS } \\
\text { - } 13 \% \text { for HVAC cooling capacity - PASS }\end{array}$ \\
\hline
\end{tabular}

Table 14: Estimated HVAC Capacity Reduction

\begin{tabular}{l|c|c|c} 
& & $\begin{array}{l}\text { Single- } \\
\text { Pane } \\
\text { Secondary }\end{array}$ & $\begin{array}{l}\text { Double- } \\
\text { Pane } \\
\text { Secondary }\end{array}$ \\
\hline Heating Capacity (kBtu/hr) & 13,285 & 12,016 & 10,774 \\
\hline Cooling Capacity (kBtu/hr) & 12,974 & 11,904 & 11,258 \\
\hline Reduction in Heating Capacity (\%) & n/a & $10 \%$ & $19 \%$ \\
\hline $\begin{array}{l}\text { Reduction in Cooling Capacity (\%) } \\
\text { Estimated total HVAC capacity savings }\end{array}$ & n/a & $8 \%$ & $13 \%$ \\
\hline $\begin{array}{l}\text { Annualized HVAC capacity savings } \\
\text { (\$/yr) }\end{array}$ & n/a & 94,862 & 171,515 \\
\hline
\end{tabular}

\section{COST EFFECTIVENESS}

Economic evaluations of the window technology were conducted for simple payback ${ }^{4}$ and SIR. $^{5}$ Savings were estimated from energy savings only. Energy cost savings were estimated using the EnergyPlus model with a midlevel GSA utility rate. A window life expectancy of 20 years was assumed for the SIR analysis. The costs of the windows were collected from actual installation costs, which included materials and labor. The costs were then normalized by window area to arrive at costs per area $\left(\$ / \mathrm{ft}^{2}\right)$ that were used to estimate the total costs for analysis of the Large Office Building model. Note that the first cost was used in the analysis of the secondary window cases. More details on analysis and cost assumptions can be found in Table 15. Details of GSA utility rates can be found in Table 16.

\footnotetext{
${ }^{4}$ Simple payback refers to the time required to recoup the funds expended in an investment.

${ }^{5}$ Savings-to-investment ratio is a ratio of the present value savings to the present value costs of an energy conservation measure.
} 
Table 15: Window Costs

\begin{tabular}{|c|c|c|c|c|c|}
\hline Window Type & $\begin{array}{c}\text { Window } \\
\text { Area } \\
\left(\mathrm{ft}^{2}\right)\end{array}$ & $\begin{array}{c}\text { Material } \\
\text { Cost (\$) }\end{array}$ & $\begin{array}{l}\text { Labor } \\
\text { Cost } \\
\text { (\$) }\end{array}$ & $\begin{array}{c}\text { Total } \\
\text { Installed } \\
\text { Cost (\$) }\end{array}$ & $\begin{array}{c}\text { Cost per } \\
\text { Window } \\
\text { Area } \\
\left(\$ / \mathrm{ft}^{2}\right) \\
\text { Used in } \\
\text { Analysis }\end{array}$ \\
\hline Single-pane secondary & 98 & $\$ 1,666$ & $\$ 112$ & $\$ 1,779$ & $\$ 18.15$ \\
\hline Double-pane secondary & 65 & $\$ 1,430$ & $\$ 75$ & $\$ 1,505$ & $\$ 23.15$ \\
\hline
\end{tabular}

Table 16: GSA Utility Rates

\begin{tabular}{l|c|c}
$\begin{array}{l}\text { Utility } \\
\text { Rate* }\end{array}$ & $\begin{array}{c}\text { Electricity } \\
\text { (\$/kWh) }\end{array}$ & $\begin{array}{c}\text { Natural } \\
\text { Gas } \\
\text { (\$⿳㇒⿴囗十 } / \mathbf{M B t u})\end{array}$ \\
\hline Low & 0.078 & 5.516 \\
\hline Medium & 0.113 & 7.434 \\
\hline High & 0.180 & 10.506 \\
\hline \multicolumn{2}{l}{ * Rates were provided by GSA. }
\end{tabular}

Success criteria for the secondary windows were a payback of less than 15 years and a SIR greater than 1.

Most success criteria were met. Simply payback for the secondary windows is between 11 and 18 years and SIR is 1.1-1.9. The economics of the double-pane secondary windows were significantly improved when compared to single-pane secondary windows. The thermal performance improvement of the double-pane secondary windows is significantly greater than that of the single-pane secondary windows while the cost increase is marginal. Details of the cost-effectiveness criteria and results can be found in Table 17 and Table 18.

Table 17: Quantitative Objectives and Results - Cost Effectiveness

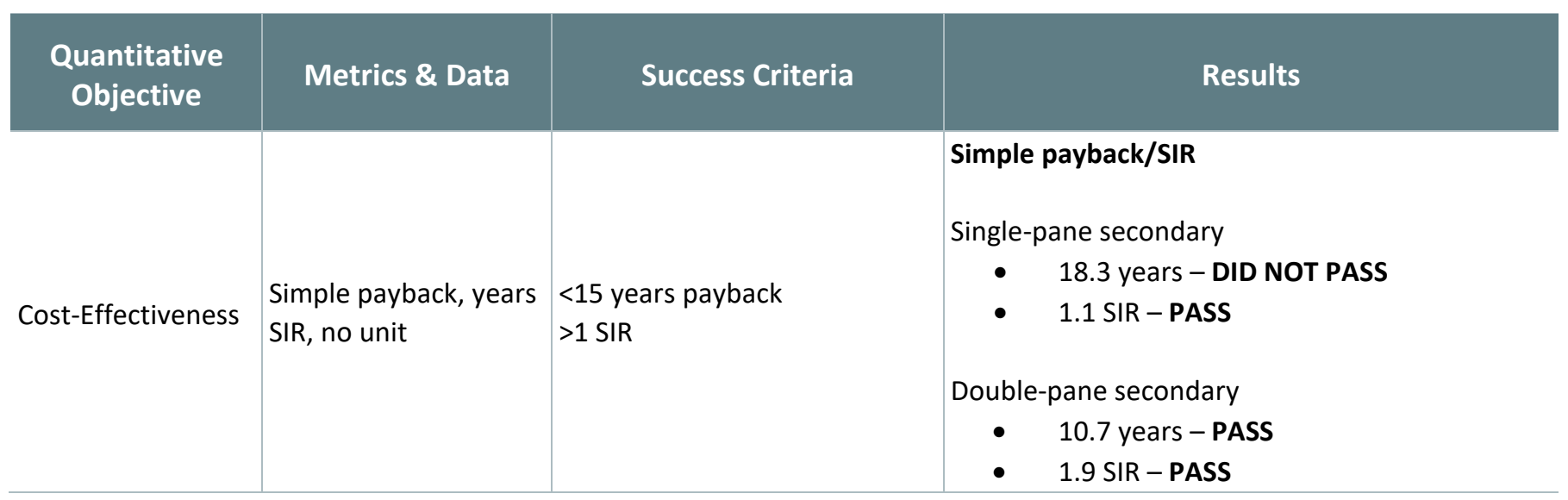




\section{Table 18: Cost Effectiveness - Simple Payback and Savings-to-Investment Ratio}

\begin{tabular}{l|c|c}
$\begin{array}{l}\text { Performance } \\
\text { Metric }\end{array}$ & $\begin{array}{l}\text { Single-Pane } \\
\text { Secondary }\end{array}$ & $\begin{array}{l}\text { Double- } \\
\text { Pane } \\
\text { Secondary }\end{array}$ \\
\hline Installed Cost $(\$)$ & 905,412 & $1,154,837$ \\
\hline Energy Savings $(\$ / y r)$ & 12,336 & 25,011 \\
\hline Simple Payback (yr) & 18.3 & 10.7 \\
\hline SIR & 1.1 & 1.9 \\
\hline
\end{tabular}

\section{CONDENSATION}

CR measures how well a window resists the formation of condensation on the inside surface. CR is scored from 1 to 100 . The rating value is based on interior surface temperatures at $30 \%, 50 \%$, and $70 \%$ indoor relative humidity for a given outside dry-bulb temperature of $0^{\circ} \mathrm{F}$ under $15 \mathrm{mph}$ wind conditions. The higher the number, the better a product is able to resist condensation. CR is meant to compare products and their potential for condensation formation. However, CR is an optional rating on the NFRC label. In general, it is recommended to select a window with an NFRC CR rating greater than $50 .{ }^{6}$ For this study, CR was estimated using the WINDOW model at $50 \%$ indoor relative humidity, outside dry-bulb temperature of $0^{\circ} \mathrm{F}$ and $15 \mathrm{mph}$ wind speed.

The success criterion for the CR rating was that it must be greater than 50 . The calculated CR for the secondary window integrated with baseline single-pane window is 44-46; therefore, they did not pass the criteria by a narrow margin. The lower CR may not be necessarily caused by the secondary window's thermal performance, but by the thermal performance of the existing single-pane window. It should also be noted that the CR rating for the existing single-pane window is low at 12-14 due to its inferior thermal performance. Details of the condensation criteria and results can be found in Table 19 and Table 20.

Table 19: Quantitative Objectives and Results - Condensation

\begin{tabular}{|c|c|c|c|}
\hline $\begin{array}{l}\text { Quantitative } \\
\text { Objective }\end{array}$ & Metrics \& Data & Success Criteria & Results \\
\hline Condensation & $\begin{array}{l}\text { Room-side glass } \\
\text { surface temperature, } \\
{ }^{\circ} \mathrm{F} \\
\text { Relative humidity, \% } \\
\text { CR rating, 0-100 }\end{array}$ & CR rating greater than 50 & $\begin{array}{l}\text { CR rating } \\
\text { Single-pane Secondary with baseline } \\
\text { Double-pane Secondary with baseline } \\
\quad 46 \text { CR - DID NOT PASS } \\
\text { CR rating for the existing single-pane window is } \\
\text { low at } 12-14 \text { due to the fact that it has inferior } \\
\text { thermal performance. The secondary windows } \\
\text { improved overall condensation rating } \\
\text { significantly. }\end{array}$ \\
\hline
\end{tabular}

${ }^{6}$ http://www.mnshi.umn.edu/kb/scale/condensationresistance.html 
Table 20: Window Performance Ratings Calculated Using the WINDOW Model

\begin{tabular}{|c|c|c|c|c|c|}
\hline & \multicolumn{2}{|c|}{ U-value } & \multirow{2}{*}{$\begin{array}{l}\text { Solar Heat } \\
\text { Gain } \\
\text { Coefficient }\end{array}$} & \multirow{2}{*}{$\begin{array}{c}\text { Visible } \\
\text { Transmittance }\end{array}$} & \multirow{2}{*}{$\begin{array}{c}\text { Condensation } \\
\text { Rating }\end{array}$} \\
\hline & $\left(\mathrm{W} / \mathrm{m}^{2} \cdot \mathrm{K}\right)$ & $\mathrm{Btu} /\left(\mathrm{h} \cdot \mathrm{ft}^{2} \cdot \mathrm{F}\right)$ & & & \\
\hline $\begin{array}{l}\text { Existing single pane } \\
\text { window }\end{array}$ & 6.799 & 1.197 & 0.81 & 0.84 & 12 \\
\hline $\begin{array}{l}\text { Existing single pane } \\
\text { window with metal } \\
\text { dividers }\end{array}$ & 7.475 & 1.316 & 0.79 & 0.82 & 14 \\
\hline $\begin{array}{l}\text { Single-pane secondary } \\
\text { window with baseline } \\
\text { single-pane window }\end{array}$ & 3.019 & 0.532 & 0.70 & 0.73 & 44 \\
\hline $\begin{array}{l}\text { Double-pane secondary } \\
\text { window with baseline } \\
\text { single-pane window }\end{array}$ & 1.320 & 0.232 & 0.42 & 0.58 & 46 \\
\hline
\end{tabular}

\section{THERMAL COMFORT}

Thermal comfort is the feeling of satisfaction with the thermal environment and is assessed by subjective evaluation. ASHRAE Standard 55 specifies conditions for acceptable thermal environments and is intended for use in design, operation, and commissioning of buildings and other occupied spaces. Thermal comfort analysis was conducted using the University of California at Berkeley Center for the Built Environment (CBE) Thermal Comfort Tool. ${ }^{7}$ The monitored indoor temperature and humidity ratio during occupied and unoccupied periods for the month of January (representing the winter peak month) and July (representing the summer peak month) were averaged. Other inputs, shown in Table 21, including air velocity, metabolic rate, and clothing level were assumed and used with the indoor temperatures and humidity ratios for those hours in winter and summer. Details and description of inputs can be found on the CBE Thermal Comfort Tool website.

Table 21: Inputs to the CBE Thermal Comfort Tool

\begin{tabular}{l|c|c} 
& Winter & Summer \\
\hline Air velocity [fpm] & 20 & 29.5 \\
\hline Metabolic rate [met] & 1 & 1.1 \\
\hline Clothing level [clo] & 1 & 0.5 \\
\hline
\end{tabular}

The CBE Thermal Comfort Tool calculates the predicted mean vote (PMV) and the predicted percentage of dissatisfied (PPD), the most widely used thermal comfort indices (Figure 13).

PMV is an index that aims to predict the mean value of votes of a group of occupants on a seven-point thermal sensation scale. Thermal equilibrium is obtained when an occupant's internal heat production is the same as its heat loss. The heat balance of an individual can be influenced by levels of physical activity and clothing insulation, as well as the parameters of the thermal environment. For example, thermal sensation is generally perceived as better when occupants of a space have control over indoor temperature (i.e., natural ventilation

${ }^{7}$ CBE Thermal Comfort Tool, https://comfort.cbe.berkeley.edu/ 
through opening or closing windows), as it helps to alleviate high-occupancy thermal expectations on a mechanical ventilation system. Within the PMV scale, +3 indicates "too hot," while -3 indicates "too cold."

Once the PMV is calculated, the PPD, an index that establishes a quantitative prediction of the percentage of thermally dissatisfied occupants (i.e., those who are too warm or too cold), can be determined. PPD essentially gives the percentage of people predicted to experience local discomfort. The main factors causing local discomfort are unwanted cooling or heating of an occupant's body. Common contributing factors are drafts, abnormally high vertical temperature differences between the ankles and head, and/or floor temperature. ${ }^{8}$

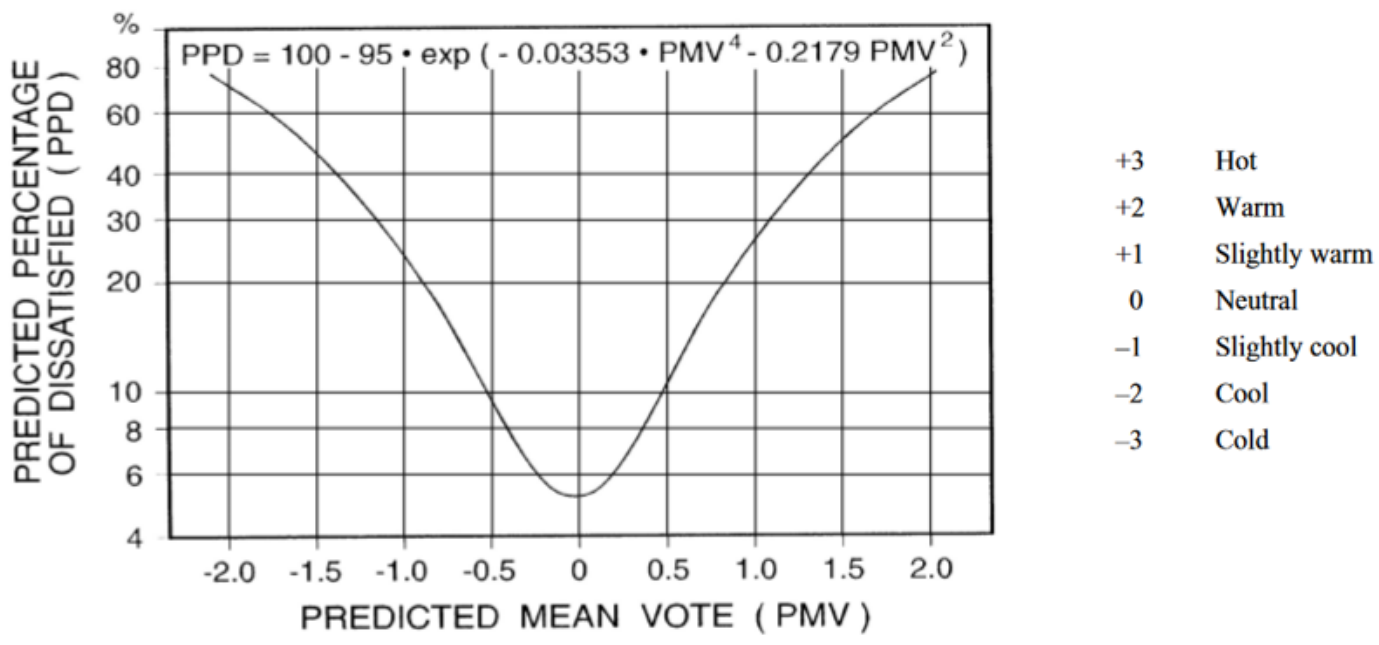

Figure 13: PMV and PPD Scale

\section{Source: ASHRAE Standard 55-2017 Thermal Environmental Conditions for Human Occupancy}

Figure 14 and Figure 16 show the plots of monitored indoor conditions from Building 53 during occupied and unoccupied periods in winter and summer within the comfort boundary on a psychrometric chart per ASHRAE Standard 55.

The thermal comfort criteria are met as the results show that the majority of the conditions were within the comfort boundary. Details of the thermal comfort criteria and results can be found in Table 23. The results show that there were a small number of hours (5\% to $10 \%$ ) that were outside the comfort boundary. However, the PMV and PPD analyses, presented in Figure 15 and Figure 17, show that the space in Building 53 was slightly cool and predicts that up to $45 \%$ of the occupants could experience some local thermal discomfort.

It should be noted that none of the measured indoor conditions were expected to have been completely affected by the presence of the window systems being evaluated. However, the indoor temperatures and humidity levels are also expected to have been produced by the HVAC system and could have been the same with or without the new windows. Therefore, the thermal comfort analysis results may not present the effects caused by the windows alone, but may also include other factors such as physical activity and clothing insulation, as well as the parameters of the thermal environment by HVAC operation.

${ }^{8}$ For more information, see “What is PMV and PPD?” https://www.simscale.com/blog/2019/09/what-is-pmv-ppd/ 


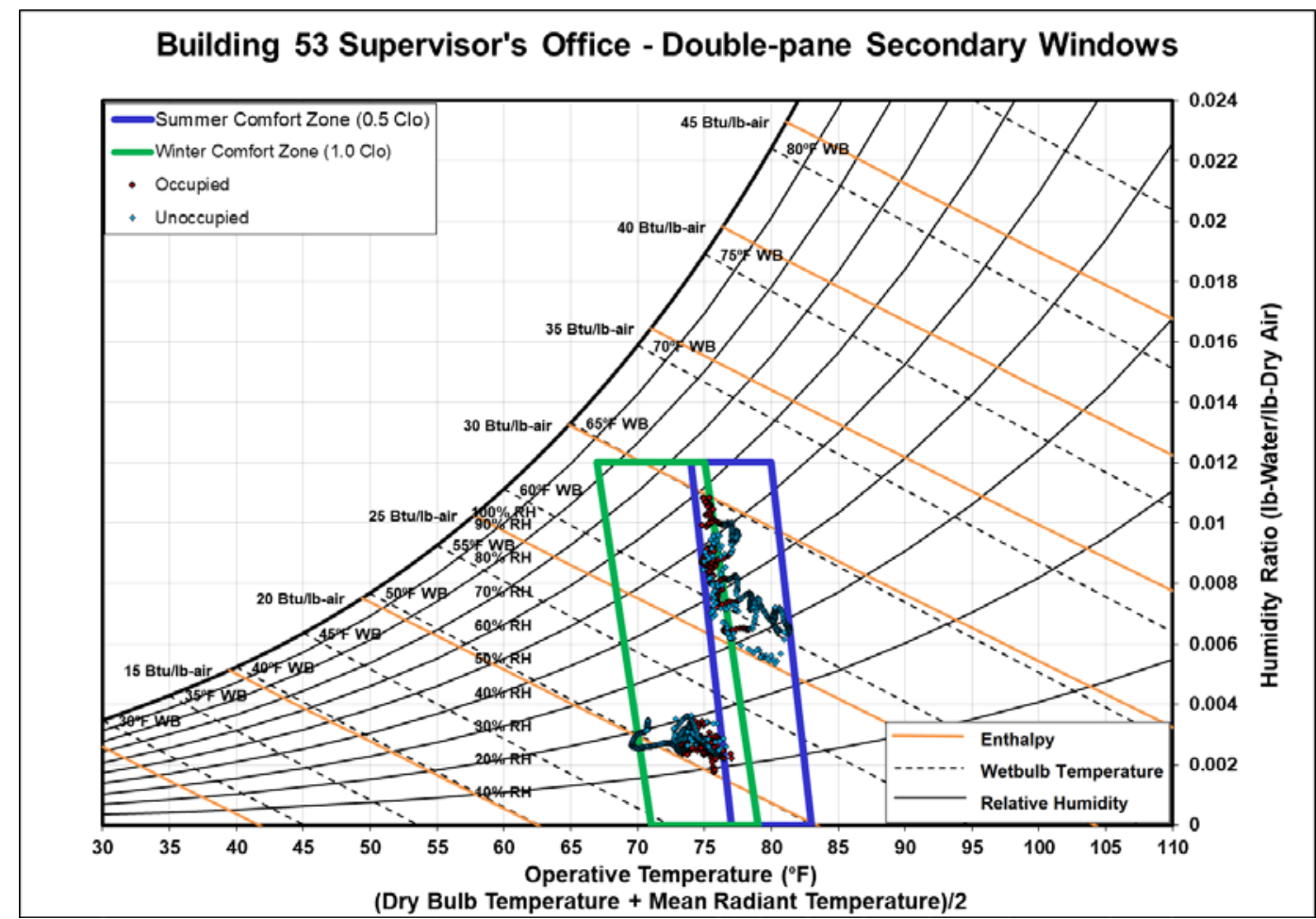

Figure 14: Building 53 Supervisor Office - indoor conditions and comfort boundary

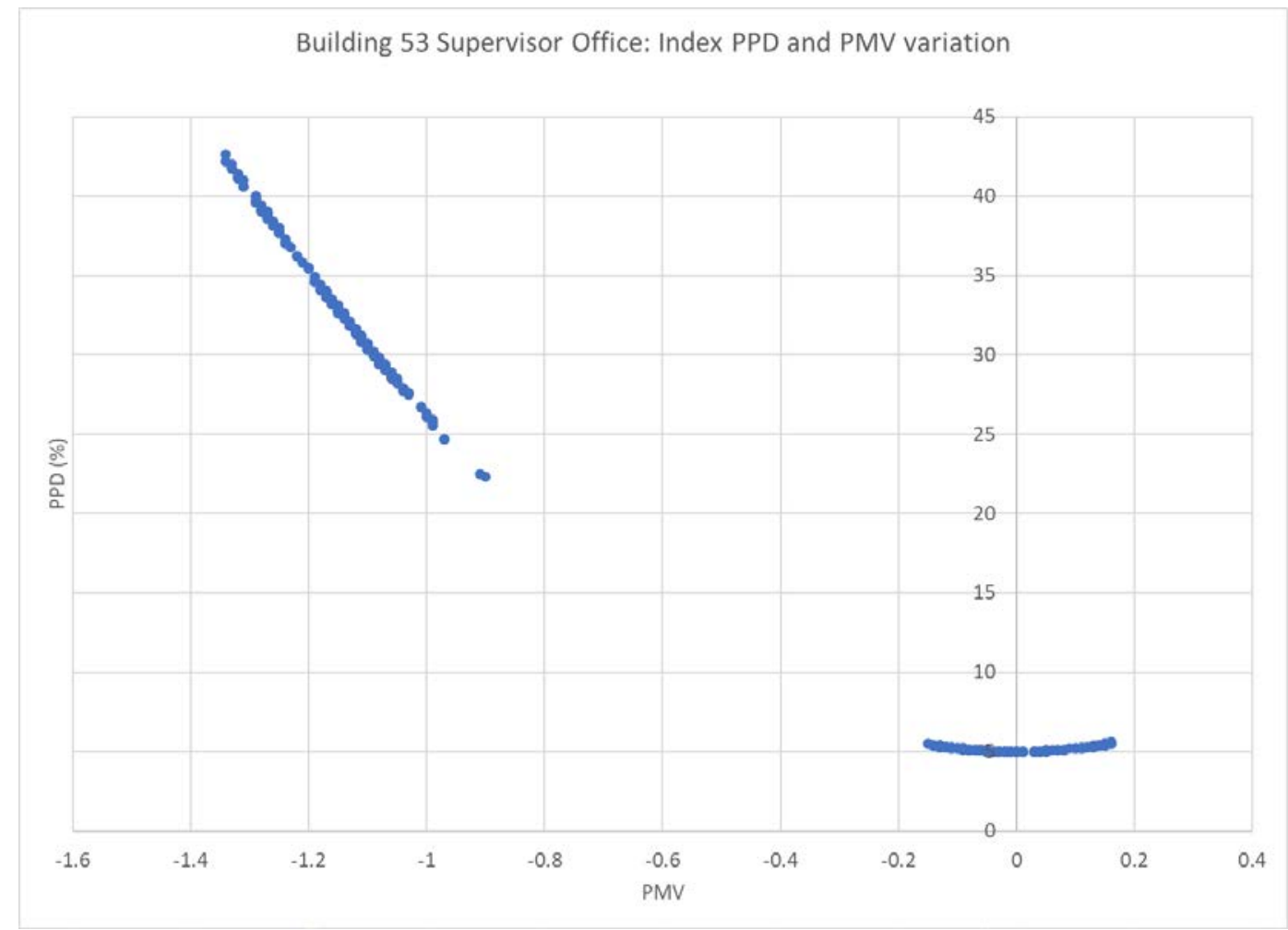

Figure 15: Building 53 Supervisor Office - PMV and PMV analysis 


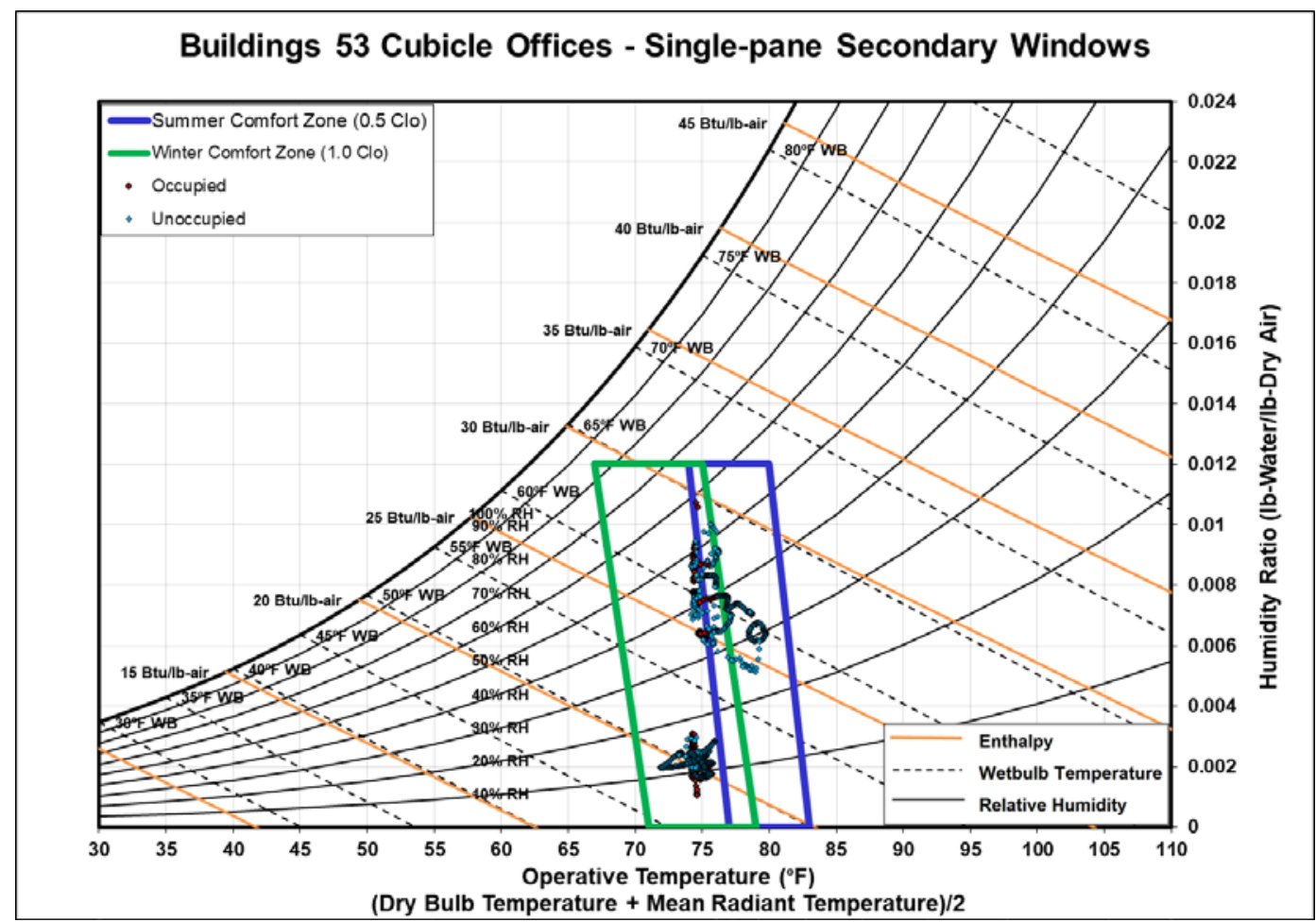

Figure 16: Building 53 Cubicle Office - indoor conditions and comfort boundary

Building 53 Cubicle Office: Index PPD and PMV variation

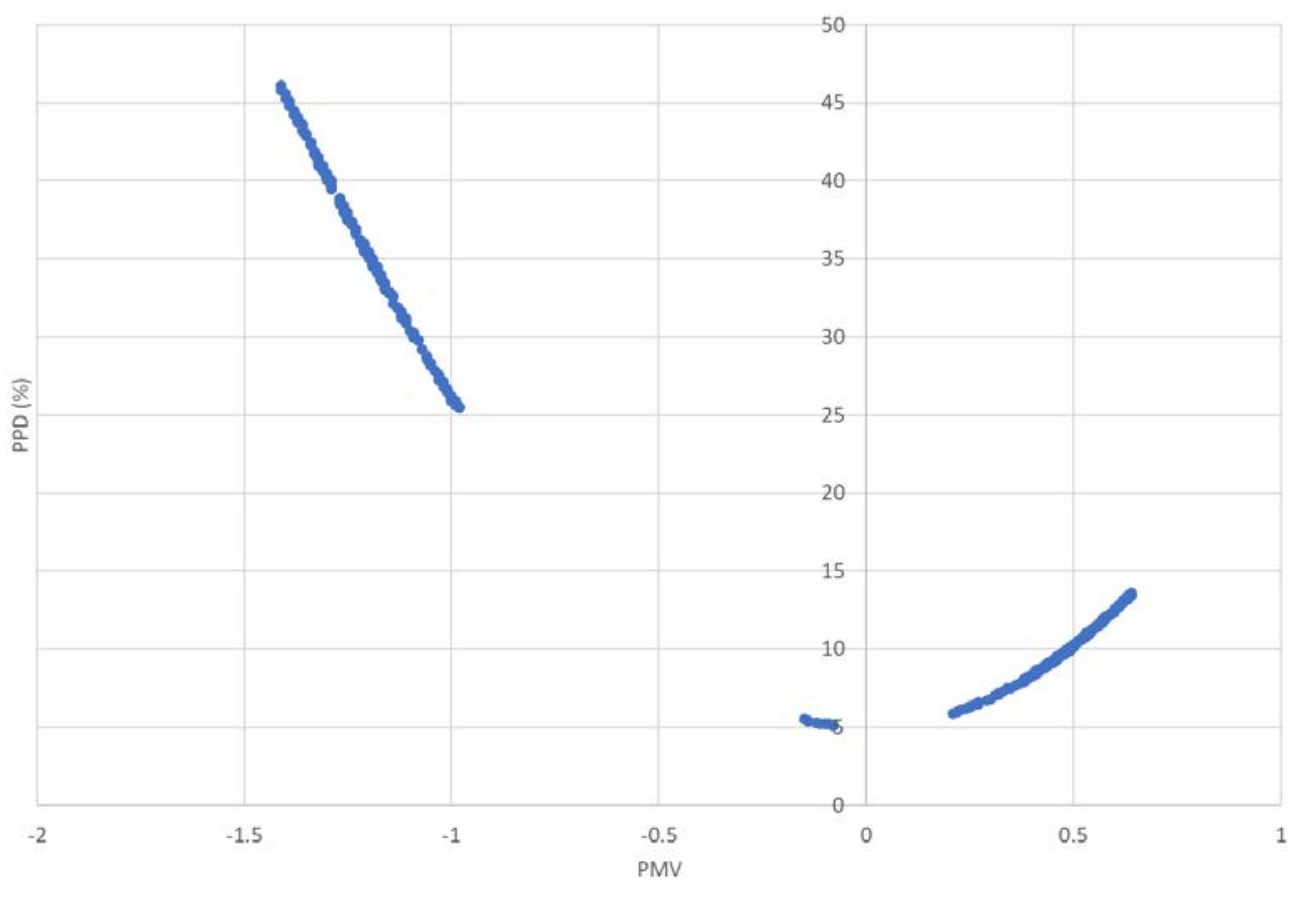

Figure 17: Building 53 Cubicle Office - PMV and PMV analysis 
Table 22: Quantitative Objectives and Results - Thermal Comfort

\begin{tabular}{|c|c|c|c|}
\hline $\begin{array}{l}\text { Quantitative } \\
\text { Objective }\end{array}$ & Metrics \& Data & Success Criteria & Results \\
\hline Thermal Comfort & $\begin{array}{l}\text { Space temperature, }{ }^{\circ} \mathrm{F} \text { and } \\
\text { relative humidity, } \% \\
\text { Room side glass surface } \\
\text { temperature, }{ }^{\circ} \mathrm{F} \\
\text { Wall temperature, }{ }^{\circ} \mathrm{F}\end{array}$ & $\begin{array}{l}\text { Space temperature and relative } \\
\text { humidity are within occupant thermal } \\
\text { comfort defined by ASHRAE Standard } \\
55-2013\end{array}$ & $\begin{array}{l}\text { Secondary window - PASS } \\
\text { A small number of hours ( } 5 \% \\
\text { to } 10 \% \text { ) fell outside the } \\
\text { comfort boundary. }\end{array}$ \\
\hline
\end{tabular}

In addition, measured temperatures at the center of the glass during the coldest period (Figure 19) show significant improvement by the secondary window. The average temperatures (Table 23) at the center of the glass of the double-pane secondary window and single-pane secondary window are $68.2^{\circ} \mathrm{F}$ and $56.7^{\circ} \mathrm{F}$, compared baselined single-pane window at $48^{\circ} \mathrm{F}$. Large temperature differences increase radiant asymmetry that contributes to occupant discomfort. ASHRAE 55 guidelines state that for vertical surfaces radiant asymmetry should be kept to less than $18^{\circ} \mathrm{F}$ (Huizenga 1999). The vertical surface radiant asymmetry of the double-pane secondary, single-pane secondary, and baselined single-pane are approximately $5^{\circ} \mathrm{F}, 16^{\circ} \mathrm{F}$, and $25^{\circ} \mathrm{F}$, respectively. For this circumstance, the vertical surface radiant asymmetry of the double-pane secondary and single-pane secondary windows are within the ASHRAE guidelines.

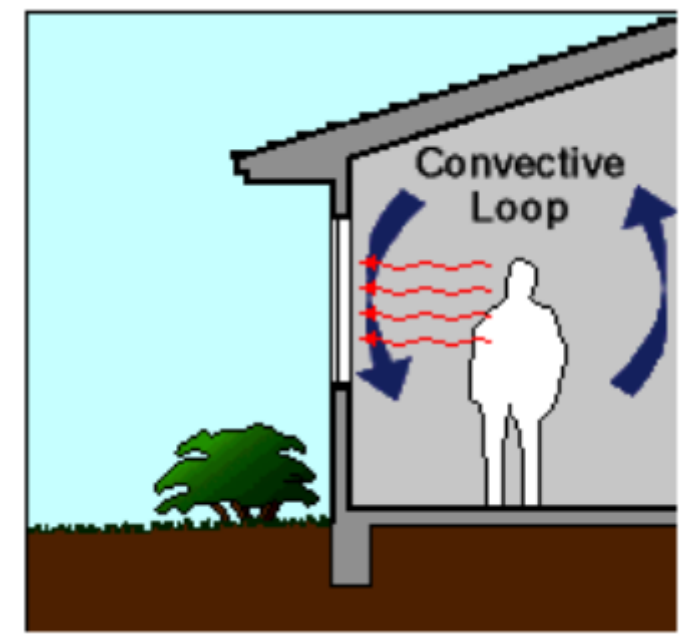

Figure 18: Convective and radiative heat transfer effects on thermal comfort

Source: Huizenga (1999)

Temperature differences between the window surface and indoor air can also induce convective heat transfer through air movement, particularly in cold conditions. Drafts caused by the air movement can also contribute to occupant discomfort. Figure 18 demonstrates convective and radiative heat transfer effects on thermal comfort. 


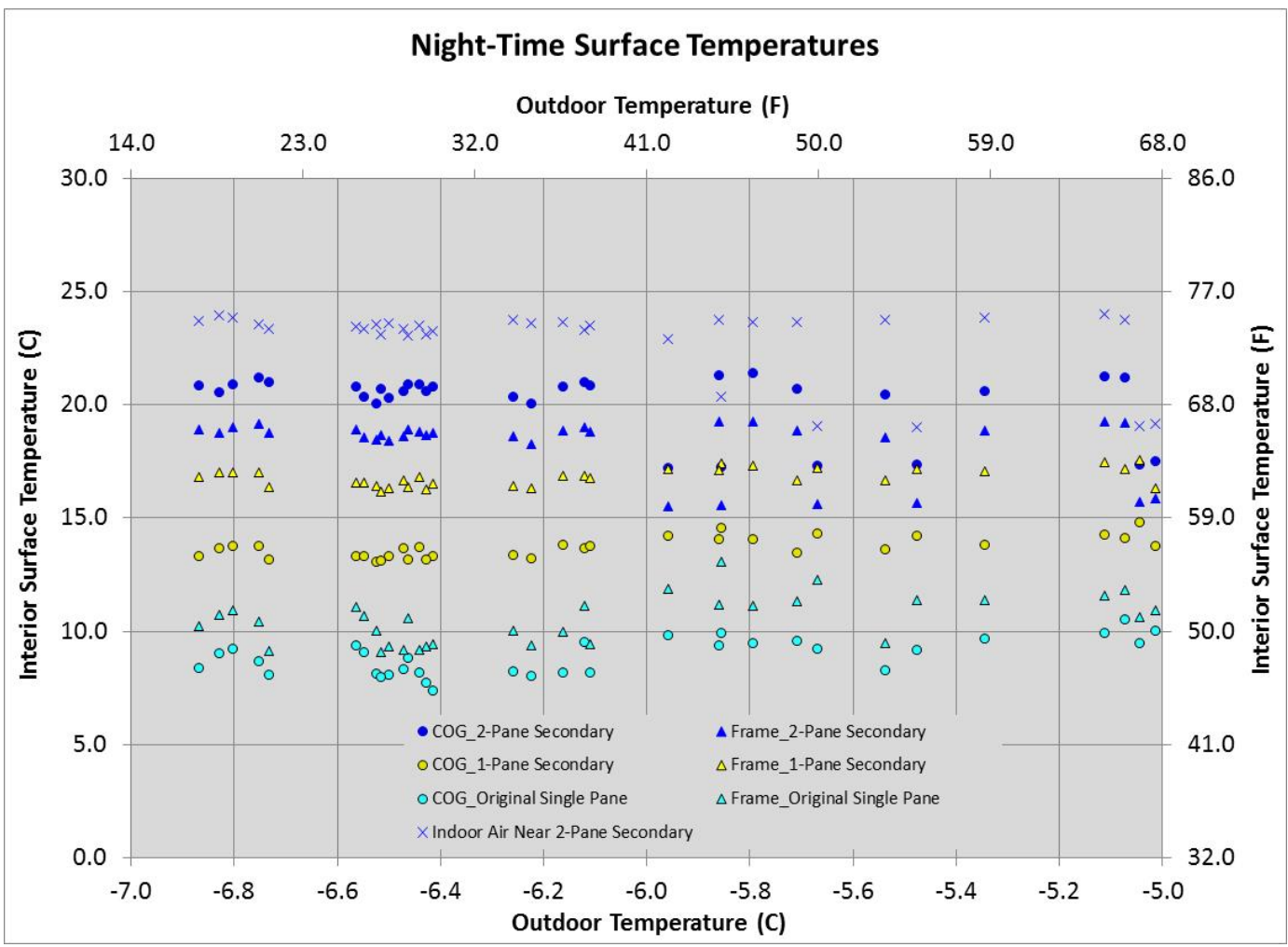

Figure 19: Surface temperatures during cold period

Table 23: Average Surface Temperature During Cold Period

\begin{tabular}{|l|c|c|c|c|}
\hline & \multicolumn{3}{|c|}{$\begin{array}{c}\text { Center of } \\
\text { Glass }\end{array}$} & \multicolumn{2}{c}{ Frame } \\
\cline { 2 - 6 } & ${ }^{\circ} \mathrm{C}$ & ${ }^{\circ} \mathrm{F}$ & ${ }^{\circ} \mathrm{C}$ & ${ }^{\circ} \mathrm{F}$ \\
\hline Double-Pane Secondary Window & 20.1 & 68.2 & 18.3 & 64.8 \\
\hline Single-Pane Secondary Window & 13.7 & 56.7 & 16.8 & 62.2 \\
\hline Baselined Single-Pane Window & 8.9 & 48.0 & 10.5 & 50.9 \\
\hline
\end{tabular}

Mean Outdoor Temperature: $-6.1^{\circ} \mathrm{C}\left(21.0^{\circ} \mathrm{F}\right)$

Mean Indoor Temperature: $22.9^{\circ} \mathrm{C}\left(73.2^{\circ} \mathrm{F}\right)$

\section{INFILTRATION}

DOE (2019a) estimates that air infiltration accounts for approximately $20 \%$ of building envelope energy use in commercial buildings (Figure 20). Energy loss due to air infiltration is greater in cold climates (Figure 21), especially for a building with old and leaky single-pane windows (Gowri, Winiarski, and Jarnagin 2009). Many old windows suffer from poor airtightness, resulting in excessive loss of heat to the outside and increasing energy use. This is due to the window deteriorating over time and forming a less effective air seal. Secondary windows could provide the additional benefit of reduced air infiltration, which results in additional energy savings. 


\section{Commercial Building Windows and Envelope}

6 Quads of energy (DOE 2014)

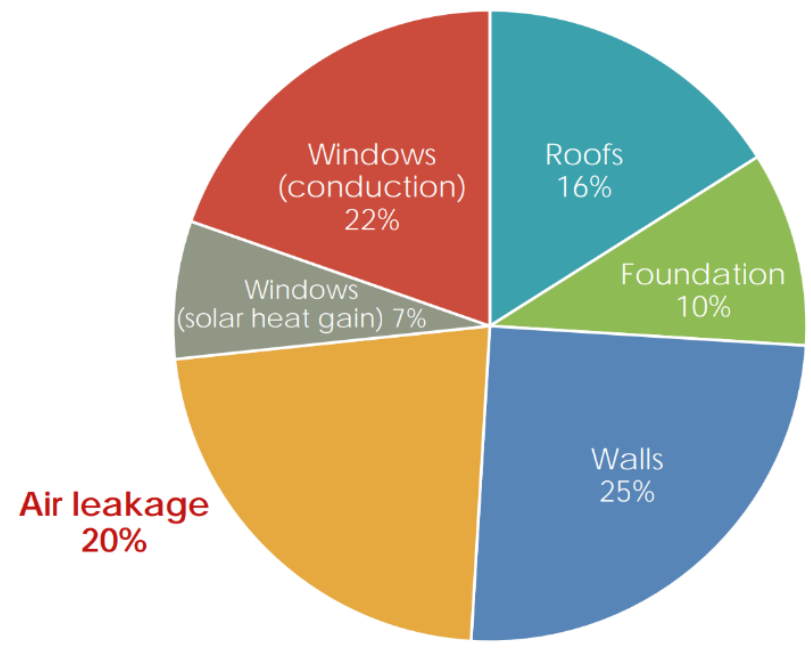

Figure 20: Energy use through windows and building envelope

Source: DOE (2019a)

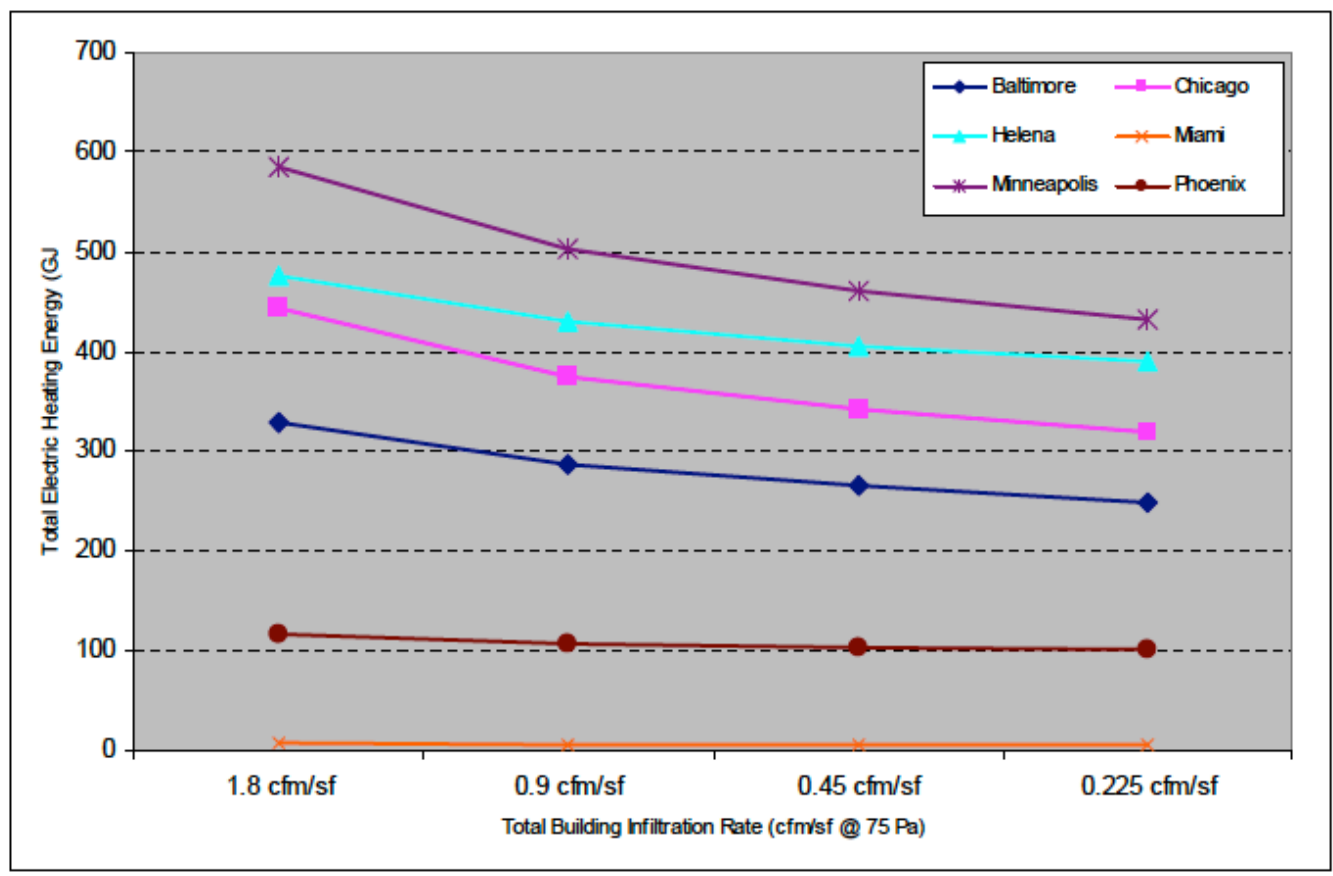

Figure 21: Impact of infiltration on total electric heating energy

Source: DOE (2009) 
At the time of $M \& V$ project plan development for this study, there was no agreed-upon measurement protocol for infiltration. The Attachments Energy Ratings Council (AERC) is in the process of establishing a standard for secondary windows in commercial buildings that will include air leakage. AERC estimates the average air infiltration for single-pane windows at $2.0 \mathrm{cfm} / \mathrm{ft}^{2}$ (AERC 2021). To achieve an ENERGY STAR rating, interior storm windows must have leakage less than $0.5 \mathrm{cfm} / \mathrm{ft}^{2}$ (DOE 2019b). From other studies, measured reduction in air leakage around windows using secondary windows varies greatly depending on the initial windows from approximately $7 \%$ (Drumheller 2007) to between $60 \%$ and $80 \%$ for very bad initial single-pane windows (Desjarlais, Childs, and Christian 1998). According to AERC third-party testing (shown in Appendix C), both the single- and double-pane secondary windows could reduce infiltration to $0.06 \mathrm{cfm} / \mathrm{ft}^{2}$ for a $97 \%$ infiltration reduction that could result in additional energy savings.

\section{QUALITATIVE RESULTS \\ OCCUPANT SURVEYS}

In addition to reduced energy consumption, the improved thermal performance of the secondary windows results in warmer room-side glass surface temperatures under cold winter conditions, thereby improving thermal comfort for the occupants and increasing usable office space near windows. A survey was developed and distributed to occupants of the spaces in Building 53 to acquire feedback regarding the thermal comfort of post-installation conditions. Details of the occupant survey form can be found in Appendix D. Details of the qualitative thermal comfort criteria and results can be found in Table 24.

\section{Occupant Survey Results and Findings, Building 53 (Secondary Windows)}

- Most survey respondents were positive and recommended the retrofit in the future.

- Thermal discomfort possibly already existed and may be caused by HVAC operation rather than the windows.

- The appearance of the secondary windows was noticeable but acceptable.

Table 34: Qualitative Objectives and Results - Thermal Comfort

Qualitative Objective

Metrics \& Data

Success Criteria

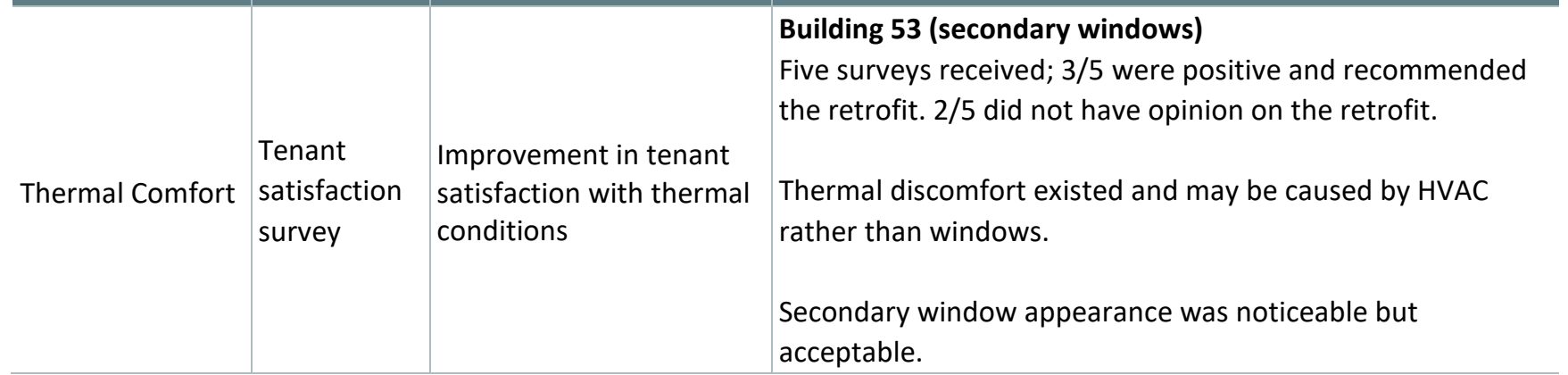

\section{EASE OF INSTALLATION}

This criterion looks at the ease of the installation of the technology. A single secondary window was installed in less than 30 minutes. During the evaluation, the secondary window was uninstalled and reinstalled several times 
for installation of thermocouples on the inner surface between the existing window and the secondary window. Details of the qualitative ease of installation criteria and results can be found in Table 25.

Table 25: Qualitative Objectives and Results - Ease of Installation

\begin{tabular}{|c|c|c|c|}
\hline $\begin{array}{l}\text { Qualitative } \\
\text { Objective }\end{array}$ & Metrics \& Data & Success Criteria & Results \\
\hline Ease of Installation & $\begin{array}{l}\text { Interview with } \\
\text { installer } \\
\text { Time required to } \\
\text { install and configure } \\
\text { Labor associated with } \\
\text { install }\end{array}$ & $<1$ day to install & $\begin{array}{l}\text { Installation of a secondary window, done by } \\
\text { one person, took approximately 7-10 } \\
\text { minutes to install. } \\
\text { The secondary window could be easily } \\
\text { installed and uninstalled - PASS }\end{array}$ \\
\hline
\end{tabular}

\section{DEPLOYABILITY}

From a technical standpoint, the secondary window is easily deployed, installed, and operated. The technology is particularly useful in buildings or areas where planning permission rules do not allow any aesthetic changes whatsoever to the external primary windows (e.g., historic buildings).

One of the main goals of this study was to evaluate the suitability for deployment of secondary windows in GSA buildings across different climate zones. The key metrics for determining suitability for deployment are simple payback or SIR. The payback is less than 15 years and the SIR is greater than 1 for both secondary windows. To evaluate the deployment potential, the energy simulation modeling and economic analysis was expanded to ten ASHRAE climate zones-1A to 6A-where the majority of GSA facilities are located. Energy cost savings were estimated for all levels of GSA utility rates (low, medium and high) as shown in Table 16. Table 26 shows that buildings with areas of 50,000 to 500,000 square feet account for $57 \%$ of the portfolio.

Table 46: GSA Portfolio by Facility Size

\begin{tabular}{c|c|c}
\multicolumn{2}{c|}{ Gross Area $\left(\mathrm{ft}^{2}\right)$} & $\begin{array}{c}\text { Percent of } \\
\text { Inventory }\end{array}$ \\
\hline From & To & \\
\hline 1 & 10,000 & $9 \%$ \\
\hline 10,001 & 25,000 & $9 \%$ \\
\hline 25,001 & 50,000 & $10 \%$ \\
\hline 50,001 & 100,000 & $17 \%$ \\
\hline 100,001 & 500,000 & $40 \%$ \\
\hline 500,001 & $1,000,000$ & $10 \%$ \\
\hline $1,000,001$ & & $5 \%$ \\
\hline
\end{tabular}

Tables 27 to 29 present estimated heating, cooling, and fan energy savings of the single-pane and double-pane secondary windows. Tables 30 to 37 show the estimated total building energy and cost savings of the single- and 
double-pane secondary windows at various utility rate levels. The estimated payback and SIR of the single-pane and double-pane secondary windows are presented in Table 38. The results show that the double-pane secondary window is cost effective for most climate zones and at the medium to high utility rate. The economic analysis and estimated savings could be used for future screening for the technology. However, for a future retrofit project, a detailed study including energy modeling analysis of the window options for the specific building is recommended due to the fact that each building is unique. The results and findings are summarized below.

\section{Single-pane Secondary Window}

\section{Estimated Heating Energy (1)}

- Heating energy reduction between $24 \%$ and $38 \%$

- Normalized heating energy savings from 0.4-7.6 kBtu/ft²/yr

Estimated Cooling Energy (2)

- Cooling energy reduction between $6 \%$ and $10 \%$

- Normalized cooling energy savings from $0.3-1.0 \mathrm{kBtu} / \mathrm{ft}^{2} / \mathrm{yr}$

Estimated Fan Energy (3)

- Fan energy reduction between $8 \%$ and $12 \%$

- Normalized fan energy savings from 0.6-1.2 kBtu/ft²/yr

Estimated HVAC Energy $(1+2+3)$

- HVAC energy reduction between $8 \%$ and $20 \%$

- Normalized HVAC energy savings from $1.9-8.8 \mathrm{kBtu} / \mathrm{ft}^{2} / \mathrm{yr}$

Estimated Total Building Energy

- Total building energy reduction between $3 \%$ and $10 \%$

- Normalized fan energy savings from $2.0-8.9 \mathrm{kBtu} / \mathrm{ft}^{2} / \mathrm{yr}$

Estimated Total Building Energy Cost and Economics

- Normalized building energy savings:

- $\$ 0.04-\$ 0.08 / \mathrm{ft}^{2} / \mathrm{yr}$ for low utility rate

○ $\$ 0.06-\$ 0.12 / \mathrm{ft}^{2} / \mathrm{yr}$ for medium utility rate

○ $\$ 0.09-\$ 0.18 / \mathrm{ft}^{2} / \mathrm{yr}$ for high utility rate

- Payback period:

○ 21.9-44.6 years for low utility rate

- 15.5-30.9 years for medium utility rate

○ 10.1-19.5 years for high utility rate

- SIR:
○ $\quad 0.4-0.9$ for low utility rate
○ $\quad 0.6-1.3$ for medium utility rate 
○ 1.0-2.0 for high utility rate

\section{Double-pane Secondary Window}

Estimated Heating Energy (1)

- Heating energy reduction between $43 \%$ and $94 \%$

- Normalized heating energy savings from $1.0-13.6 \mathrm{kBtu} / \mathrm{ft}^{2} / \mathrm{yr}$

Estimated Cooling Energy (2)

- Cooling energy reduction between $16 \%$ and $26 \%$

- Normalized cooling energy savings from 0.9-2.7 kBtu/ $\mathrm{ft}^{2} / \mathrm{yr}$

Estimated Fan Energy (3)

- Fan energy reduction between $21 \%$ and $28 \%$

- Normalized fan energy savings from $1.6-2.9 \mathrm{kBtu} / \mathrm{ft}^{2} / \mathrm{yr}$

Estimated HVAC Energy $(1+2+3)$

- HVAC energy reduction between $21 \%$ and $40 \%$

- Normalized HVAC energy savings from 5.7-17.0 kBtu/ft²/yr

Estimated Total Building Energy

- Total building energy reduction between $8 \%$ and $20 \%$

- Normalized fan energy savings from 5.7-17.0 kBtu/ft²/yr

Estimated Total Building Energy Cost and Economics

- Normalized building energy savings:

- $\$ 0.11-\$ 0.18 / \mathrm{ft}^{2} / \mathrm{yr}$ for low utility rate

- $\$ 0.16-\$ 0.26 / \mathrm{ft}^{2} / \mathrm{yr}$ for medium utility rate

○ $\$ 0.26-\$ 0.41 / \mathrm{ft}^{2} / \mathrm{yr}$ for high utility rate

- Payback period:

○ 12.5-20.4 years for low utility rate

○ 8.8-14.1 years for medium utility rate

○ $\quad 5.7-8.9$ years for high utility rate

- SIR:
○ 1.0-1.6 for low utility rate
- $1.4-2.3$ for medium utility rate
- 2.2-3.5 for high utility rate 
Table 27: Estimated Heating Energy, Normalized Heating Energy, and Heating Energy Savings

\begin{tabular}{|c|c|c|c|c|c|c|c|c|}
\hline \multirow[b]{2}{*}{ Climate Zone } & \multicolumn{3}{|c|}{ Heating Energy (kBtu) } & \multicolumn{3}{|c|}{ Normalized Heating Energy (kBtu/ft²) } & \multicolumn{2}{|c|}{$\begin{array}{l}\text { Heating Energy Savings } \\
(\%)\end{array}$} \\
\hline & $\begin{array}{l}\text { Single- } \\
\text { Pane } \\
\text { Baseline }\end{array}$ & $\begin{array}{l}\text { Single- } \\
\text { Pane } \\
\text { Secondary }\end{array}$ & $\begin{array}{l}\text { Double- } \\
\text { Pane } \\
\text { Secondary }\end{array}$ & $\begin{array}{l}\text { Single- } \\
\text { Pane } \\
\text { Baseline }\end{array}$ & $\begin{array}{l}\text { Single- } \\
\text { Pane } \\
\text { Secondary }\end{array}$ & $\begin{array}{l}\text { Double- } \\
\text { Pane } \\
\text { Secondary }\end{array}$ & $\begin{array}{c}\text { Single- } \\
\text { Pane } \\
\text { Secondary }\end{array}$ & $\begin{array}{l}\text { Double- } \\
\text { Pane } \\
\text { Secondary }\end{array}$ \\
\hline 1A Miami, Florida & 530,996 & 330,845 & 33,458 & 1.06 & 0.66 & 0.07 & $37.7 \%$ & $93.7 \%$ \\
\hline 2A Houston, Texas & $1,619,393$ & $1,031,045$ & 503,575 & 3.25 & 2.07 & 1.01 & $36.3 \%$ & $68.9 \%$ \\
\hline 2B Phoenix, Arizona & $2,055,815$ & $1,351,587$ & 740,188 & 4.12 & 2.71 & 1.48 & $34.3 \%$ & $64.0 \%$ \\
\hline 3A Atlanta, Georgia & $4,896,272$ & $3,467,485$ & $2,328,825$ & 9.82 & 6.95 & 4.67 & $29.2 \%$ & $52.4 \%$ \\
\hline 3B Las Vegas, Nevada & $3,303,673$ & $2,133,205$ & $1,254,995$ & 6.63 & 4.28 & 2.52 & $35.4 \%$ & $62.0 \%$ \\
\hline 3C San Francisco, California & $2,390,025$ & $1,528,602$ & 652,146 & 4.79 & 3.07 & 1.31 & $36.0 \%$ & $72.7 \%$ \\
\hline 4A Baltimore, Maryland & $8,599,829$ & $6,149,618$ & $4,154,074$ & 17.25 & 12.33 & 8.33 & $28.5 \%$ & $51.7 \%$ \\
\hline 5A Chicago, Illinois & $11,878,594$ & $8,737,120$ & $6,063,139$ & 23.82 & 17.52 & 12.16 & $26.4 \%$ & $49.0 \%$ \\
\hline 5B Boulder, Colorado & $9,339,174$ & $6,706,773$ & $4,497,108$ & 18.73 & 13.45 & 9.02 & $28.2 \%$ & $51.8 \%$ \\
\hline 6A Minneapolis, Minnesota & $15,786,918$ & $11,999,791$ & $9,025,797$ & 31.66 & 24.07 & 18.10 & $24.0 \%$ & $42.8 \%$ \\
\hline
\end{tabular}


Table 28: Estimated Cooling Energy, Normalized Cooling Energy, and Cooling Energy Savings

\begin{tabular}{|c|c|c|c|c|c|c|c|c|}
\hline \multirow[b]{2}{*}{ Climate Zone } & \multicolumn{3}{|c|}{ Cooling Energy (kBtu) } & \multicolumn{3}{|c|}{ Normalized Cooling Energy (kBtu/ft²) } & \multicolumn{2}{|c|}{$\begin{array}{c}\text { Cooling Energy Savings } \\
(\%)\end{array}$} \\
\hline & $\begin{array}{c}\text { Single- } \\
\text { Pane } \\
\text { Baseline }\end{array}$ & $\begin{array}{c}\text { Single- } \\
\text { Pane } \\
\text { Secondary }\end{array}$ & $\begin{array}{l}\text { Double- } \\
\text { Pane } \\
\text { Secondary }\end{array}$ & $\begin{array}{l}\text { Single- } \\
\text { Pane } \\
\text { Baseline }\end{array}$ & $\begin{array}{l}\text { Single- } \\
\text { Pane } \\
\text { Secondary }\end{array}$ & $\begin{array}{l}\text { Double- } \\
\text { Pane } \\
\text { Secondary }\end{array}$ & $\begin{array}{c}\text { Single- } \\
\text { Pane } \\
\text { Secondary }\end{array}$ & $\begin{array}{c}\text { Double- } \\
\text { Pane } \\
\text { Secondary }\end{array}$ \\
\hline 1A Miami, Florida & $8,208,580$ & $7,750,575$ & $6,915,729$ & 16.46 & 15.55 & 13.87 & $5.6 \%$ & $15.7 \%$ \\
\hline 2A Houston, Texas & $8,483,399$ & $7,961,503$ & $7,132,428$ & 17.01 & 15.97 & 14.31 & $6.2 \%$ & $15.9 \%$ \\
\hline 2B Phoenix, Arizona & $5,950,244$ & $5,467,673$ & $4,726,461$ & 11.93 & 10.97 & 9.48 & $8.1 \%$ & $20.6 \%$ \\
\hline 3A Atlanta, Georgia & $6,140,594$ & $5,652,288$ & $4,879,590$ & 12.32 & 11.34 & 9.79 & $8.0 \%$ & $20.5 \%$ \\
\hline 3B Las Vegas, Nevada & $4,616,571$ & $4,246,884$ & $3,650,072$ & 9.26 & 8.52 & 7.32 & $8.0 \%$ & $20.9 \%$ \\
\hline 3C San Francisco, California & $4,356,888$ & $4,005,759$ & $3,417,819$ & 8.74 & 8.03 & 6.85 & $8.1 \%$ & $21.6 \%$ \\
\hline 4A Baltimore, Maryland & $5,201,563$ & $4,670,179$ & $3,869,662$ & 10.43 & 9.37 & 7.76 & $10.2 \%$ & $25.6 \%$ \\
\hline 5A Chicago, Illinois & $2,404,593$ & $2,241,986$ & $1,934,040$ & 4.82 & 4.50 & 3.88 & $6.8 \%$ & $19.6 \%$ \\
\hline 5B Boulder, Colorado & $2,619,994$ & $2,393,959$ & $2,052,763$ & 5.25 & 4.80 & 4.12 & $8.6 \%$ & $21.7 \%$ \\
\hline 6A Minneapolis, Minnesota & $2,494,607$ & $2,333,914$ & $2,026,310$ & 5.00 & 4.68 & 4.06 & $6.4 \%$ & $18.8 \%$ \\
\hline
\end{tabular}


Table 29: Estimated Fan Energy, Normalized Fan Energy, and Fan Energy Savings

\begin{tabular}{|c|c|c|c|c|c|c|c|c|}
\hline \multirow[b]{2}{*}{ Climate Zone } & \multicolumn{3}{|c|}{ Fan Energy (kBtu) } & \multicolumn{3}{|c|}{ Normalized Fan Energy (kBtu/ft²) } & \multicolumn{2}{|c|}{ Fan Energy Savings (\%) } \\
\hline & $\begin{array}{l}\text { Single- } \\
\text { Pane } \\
\text { Baseline }\end{array}$ & $\begin{array}{c}\text { Single- } \\
\text { Pane } \\
\text { Secondary }\end{array}$ & $\begin{array}{c}\text { Double- } \\
\text { Pane } \\
\text { Secondary }\end{array}$ & $\begin{array}{l}\text { Single- } \\
\text { Pane } \\
\text { Baseline }\end{array}$ & $\begin{array}{c}\text { Single- } \\
\text { Pane } \\
\text { Secondary }\end{array}$ & $\begin{array}{l}\text { Double- } \\
\text { Pane } \\
\text { Secondary }\end{array}$ & $\begin{array}{c}\text { Single- } \\
\text { Pane } \\
\text { Secondary }\end{array}$ & $\begin{array}{c}\text { Double- } \\
\text { Pane } \\
\text { Secondary }\end{array}$ \\
\hline 1A Miami, Florida & $3,833,143$ & $3,533,775$ & $3,010,722$ & 7.69 & 7.09 & 6.04 & $7.8 \%$ & $21.5 \%$ \\
\hline 2A Houston, Texas & $3,862,383$ & $3,513,188$ & $2,971,738$ & 7.75 & 7.05 & 5.96 & $9.0 \%$ & $23.1 \%$ \\
\hline 2B Phoenix, Arizona & $4,648,398$ & $4,183,361$ & $3,502,270$ & 9.32 & 8.39 & 7.02 & $10.0 \%$ & $24.7 \%$ \\
\hline 3A Atlanta, Georgia & $3,925,356$ & $3,534,524$ & $2,957,313$ & 7.87 & 7.09 & 5.93 & $10.0 \%$ & $24.7 \%$ \\
\hline 3B Las Vegas, Nevada & $4,634,864$ & $4,114,057$ & $3,390,351$ & 9.30 & 8.25 & 6.80 & $11.2 \%$ & $26.9 \%$ \\
\hline 3C San Francisco, California & $3,522,847$ & $3,192,409$ & $2,639,547$ & 7.07 & 6.40 & 5.29 & $9.4 \%$ & $25.1 \%$ \\
\hline 4A Baltimore, Maryland & $3,890,827$ & $3,455,684$ & $2,861,005$ & 7.80 & 6.93 & 5.74 & $11.2 \%$ & $26.5 \%$ \\
\hline 5A Chicago, Illinois & $4,014,081$ & $3,600,634$ & $2,923,466$ & 8.05 & 7.22 & 5.86 & $10.3 \%$ & $27.2 \%$ \\
\hline 5B Boulder, Colorado & $5,091,503$ & $4,489,279$ & $3,666,849$ & 10.21 & 9.00 & 7.35 & $11.8 \%$ & $28.0 \%$ \\
\hline 6A Minneapolis, Minnesota & $4,368,811$ & $3,935,242$ & $3,292,811$ & 8.76 & 7.89 & 6.60 & $9.9 \%$ & $24.6 \%$ \\
\hline
\end{tabular}


Table 30: Estimated Total Building Energy

\begin{tabular}{|c|c|c|c|c|c|c|c|c|c|}
\hline \multirow{3}{*}{ Climate Zone } & \multicolumn{9}{|c|}{ Total Building Energy (kBtu) } \\
\hline & \multicolumn{3}{|c|}{ Single-Pane Baseline } & \multicolumn{3}{|c|}{ Single-Pane Secondary } & \multicolumn{3}{|c|}{ Double-Pane Secondary } \\
\hline & $\begin{array}{c}\text { Electricity } \\
\text { (kBtu) }\end{array}$ & $\begin{array}{c}\text { Natural } \\
\text { Gas } \\
\text { (kBtu) }\end{array}$ & $\begin{array}{c}\text { Total } \\
\text { (kBtu) }\end{array}$ & $\begin{array}{c}\text { Electricity } \\
\text { (kBtu) }\end{array}$ & $\begin{array}{c}\text { Natural } \\
\text { Gas } \\
\text { (kBtu) }\end{array}$ & $\begin{array}{c}\text { Total } \\
\text { (kBtu) }\end{array}$ & $\begin{array}{c}\text { Electricity } \\
\text { (kBtu) }\end{array}$ & $\begin{array}{c}\text { Natural } \\
\text { Gas } \\
\text { (kBtu) }\end{array}$ & $\begin{array}{c}\text { Total } \\
\text { (kBtu) }\end{array}$ \\
\hline 1A Miami, Florida & $34,189,147$ & 760,453 & $34,949,600$ & $33,348,917$ & 560,321 & $33,909,238$ & $31,829,083$ & 262,924 & $32,092,007$ \\
\hline 2A Houston, Texas & $34,651,549$ & $1,871,200$ & $36,522,749$ & $33,629,006$ & $1,282,852$ & $34,911,858$ & $32,044,379$ & 755,382 & $32,799,761$ \\
\hline 2B Phoenix, Arizona & $32,213,167$ & $2,309,082$ & $34,522,249$ & $31,134,371$ & $1,604,853$ & $32,739,224$ & $29,503,955$ & 993,464 & $30,497,419$ \\
\hline 3A Atlanta, Georgia & $31,918,443$ & $5,186,256$ & $37,104,699$ & $30,855,893$ & $3,757,450$ & $34,613,343$ & $29,224,889$ & $2,618,800$ & $31,843,689$ \\
\hline 3B Las Vegas, Nevada & $30,357,995$ & $3,584,000$ & $33,941,995$ & $29,357,725$ & $2,413,531$ & $31,771,256$ & $27,861,814$ & $1,535,331$ & $29,397,145$ \\
\hline 3C San Francisco, California & $28,955,405$ & $2,684,446$ & $31,639,851$ & $28,153,751$ & $1,823,022$ & $29,976,773$ & $26,823,376$ & 946,575 & $27,769,951$ \\
\hline 4A Baltimore, Maryland & $30,781,091$ & $8,919,897$ & $39,700,988$ & $29,565,496$ & $6,469,667$ & $36,035,163$ & $27,818,878$ & $4,474,123$ & $32,293,001$ \\
\hline 5A Chicago, Illinois & $26,619,899$ & $12,224,149$ & $38,844,048$ & $25,984,596$ & $9,082,647$ & $35,067,243$ & $24,886,142$ & $6,408,656$ & $31,294,798$ \\
\hline 5B Boulder, Colorado & $27,907,726$ & $9,677,592$ & $37,585,318$ & $27,001,973$ & $7,045,182$ & $34,047,155$ & $25,737,614$ & $4,835,526$ & $30,573,140$ \\
\hline 6A Minneapolis, Minnesota & $27,128,839$ & $16,151,287$ & $43,280,126$ & $26,475,821$ & $12,364,151$ & $38,839,972$ & $25,405,527$ & $9,390,157$ & $34,795,684$ \\
\hline
\end{tabular}


Table 31: Estimated Normalized Total Building Energy and Savings

\begin{tabular}{|c|c|c|c|c|c|c|c|c|c|c|c|}
\hline \multirow[b]{3}{*}{ Climate Zone } & \multicolumn{11}{|c|}{ Normalized Building Energy (kBtu/ft²) } \\
\hline & \multicolumn{3}{|c|}{ Single-Pane Baseline } & \multicolumn{4}{|c|}{ Single-Pane Secondary } & \multicolumn{4}{|c|}{ Double-Pane Secondary } \\
\hline & $\begin{array}{c}\text { Electricity } \\
(\mathrm{kBtu} / \\
\left.\mathrm{ft}^{2}\right)\end{array}$ & $\begin{array}{c}\text { Natural } \\
\text { Gas } \\
(\mathrm{kBtu} / \\
\left.\mathrm{ft}^{2}\right)\end{array}$ & $\begin{array}{c}\text { Total } \\
\text { (kBtu/ } \\
\left.\mathrm{ft}^{2}\right)\end{array}$ & $\begin{array}{c}\text { Electricity } \\
(\mathrm{kBtu} / \\
\left.\mathrm{ft}^{2}\right)\end{array}$ & $\begin{array}{c}\text { Natural } \\
\text { Gas } \\
(\mathrm{kBtu} / \\
\left.\mathrm{ft}^{2}\right)\end{array}$ & $\begin{array}{c}\text { Total } \\
(\mathrm{kBtu} / \\
\left.\mathrm{ft}^{2}\right)\end{array}$ & $\begin{array}{c}\text { Savings } \\
\text { (kBtu/ } \\
\left.\mathrm{ft}^{2}\right)\end{array}$ & $\begin{array}{c}\text { Electricity } \\
(\mathbf{k B t u} / \\
\left.\mathrm{ft}^{\mathbf{2}}\right)\end{array}$ & $\begin{array}{c}\text { Natural } \\
\text { Gas } \\
\left(\mathrm{kBtu}^{2} /\right. \\
\left.\mathrm{ft}^{2}\right)\end{array}$ & $\begin{array}{c}\text { Total } \\
\left(\mathrm{kBtu} / \mathrm{ft}^{2}\right)\end{array}$ & $\begin{array}{r}\text { Savings } \\
\left(\mathrm{kBtu} / \mathrm{ft}^{2}\right)\end{array}$ \\
\hline 1A Miami, Florida & 68.57 & 1.53 & 70.10 & 66.89 & 1.12 & 68.01 & 2.09 & 63.84 & 0.53 & 64.37 & 5.73 \\
\hline 2A Houston, Texas & 69.50 & 3.75 & 73.25 & 67.45 & 2.57 & 70.02 & 3.23 & 64.27 & 1.52 & 65.79 & 7.47 \\
\hline 2B Phoenix, Arizona & 64.61 & 4.63 & 69.24 & 62.45 & 3.22 & 65.66 & 3.58 & 59.18 & 1.99 & 61.17 & 8.07 \\
\hline 3A Atlanta, Georgia & 64.02 & 10.40 & 74.42 & 61.89 & 7.54 & 69.42 & 5.00 & 58.62 & 5.25 & 63.87 & 10.55 \\
\hline 3B Las Vegas, Nevada & 60.89 & 7.19 & 68.08 & 58.88 & 4.84 & 63.72 & 4.35 & 55.88 & 3.08 & 58.96 & 9.12 \\
\hline 3C San Francisco, California & 58.07 & 5.38 & 63.46 & 56.47 & 3.66 & 60.12 & 3.34 & 53.80 & 1.90 & 55.70 & 7.76 \\
\hline 5A Chicago, Illinois & 53.39 & 24.52 & 77.91 & 52.12 & 18.22 & 70.33 & 7.58 & 49.91 & 12.85 & 62.77 & 15.14 \\
\hline 5B Boulder, Colorado & 55.97 & 19.41 & 75.38 & 54.16 & 14.13 & 68.29 & 7.10 & 51.62 & 9.70 & 61.32 & 14.06 \\
\hline 6A Minneapolis, Minnesota & 54.41 & 32.39 & 86.81 & 53.10 & 24.80 & 77.90 & 8.91 & 50.95 & 18.83 & 69.79 & 17.02 \\
\hline
\end{tabular}


Table 32: Estimated Total Building Energy Cost - Low Utility Rate

\begin{tabular}{|c|c|c|c|c|c|c|c|c|c|c|c|}
\hline \multirow{3}{*}{ Climate Zone } & \multicolumn{11}{|c|}{ Total Building Energy Cost (\$) - Low Utility Rate } \\
\hline & \multicolumn{3}{|c|}{ Single-Pane Baseline } & \multicolumn{4}{|c|}{ Single-Pane Secondary } & \multicolumn{4}{|c|}{ Double-Pane Secondary } \\
\hline & $\begin{array}{c}\text { Electricity } \\
\text { (\$) }\end{array}$ & $\begin{array}{l}\text { Natural } \\
\text { Gas (\$) }\end{array}$ & $\begin{array}{c}\text { Total } \\
\text { (\$) }\end{array}$ & $\begin{array}{c}\text { Electricity } \\
\text { (\$) }\end{array}$ & $\begin{array}{l}\text { Natural } \\
\text { Gas (\$) }\end{array}$ & $\begin{array}{l}\text { Total } \\
\text { (\$) }\end{array}$ & $\begin{array}{l}\text { Savings } \\
\text { (\$) }\end{array}$ & $\begin{array}{c}\text { Electricity } \\
\text { (\$) }\end{array}$ & $\begin{array}{l}\text { Natural } \\
\text { Gas (\$) }\end{array}$ & $\begin{array}{c}\text { Total } \\
\text { (\$) }\end{array}$ & $\begin{array}{c}\text { Savings } \\
\text { (\$) }\end{array}$ \\
\hline 1A Miami, Florida & 781,352 & 4,195 & 785,546 & 762,149 & 3,091 & 765,240 & 20,306 & 727,415 & 1,450 & 728,866 & 56,681 \\
\hline 2A Houston, Texas & 791,919 & 10,322 & 802,241 & 768,550 & 7,076 & 775,627 & 26,614 & 732,336 & 4,167 & 736,502 & 65,739 \\
\hline 2B Phoenix, Arizona & 736,193 & 12,737 & 748,930 & 711,539 & 8,852 & 720,391 & 28,539 & 674,277 & 5,480 & 679,757 & 69,173 \\
\hline 3A Atlanta, Georgia & 729,458 & 28,607 & 758,065 & 705,174 & 20,726 & 725,900 & 32,165 & 667,900 & 14,445 & 682,345 & 75,720 \\
\hline 3B Las Vegas, Nevada & 693,795 & 19,769 & 713,565 & 670,935 & 13,313 & 684,248 & 29,316 & 636,748 & 8,469 & 645,217 & 68,348 \\
\hline 3C San Francisco, California & 661,741 & 14,807 & 676,548 & 643,420 & 10,056 & 653,476 & 23,072 & 613,016 & 5,221 & 618,237 & 58,311 \\
\hline 4A Baltimore, Maryland & 703,465 & 49,202 & 752,667 & 675,684 & 35,687 & 711,370 & 41,296 & 635,767 & 24,679 & 660,446 & 92,221 \\
\hline 5A Chicago, Illinois & 608,366 & 67,428 & 675,794 & 593,847 & 50,100 & 643,946 & 31,848 & 568,743 & 35,350 & 604,093 & 71,701 \\
\hline 6A Minneapolis, Minnesota & 619,997 & 89,090 & 709,087 & 605,073 & 68,201 & 673,274 & 35,814 & 580,613 & 51,796 & 632,409 & 76,679 \\
\hline
\end{tabular}


Table 33: Estimated Normalized Total Building Energy Cost - Low Utility Rate

\begin{tabular}{|c|c|c|c|c|c|c|c|c|c|c|c|}
\hline \multirow{3}{*}{ Climate Zone } & \multicolumn{11}{|c|}{ Normalized Total Building Energy Cost (\$) - Low Utility Rate } \\
\hline & \multicolumn{3}{|c|}{ Single-Pane Baseline } & \multicolumn{4}{|c|}{ Single-Pane Secondary } & \multicolumn{4}{|c|}{ Double-Pane Secondary } \\
\hline & $\begin{array}{c}\text { Electricity } \\
\left(\$ / \mathrm{ft}^{2}\right)\end{array}$ & $\begin{array}{c}\text { Natural } \\
\text { Gas } \\
\left(\$ / \mathrm{ft}^{2}\right)\end{array}$ & $\begin{array}{c}\text { Total } \\
\left(\$ / \mathrm{ft}^{2}\right)\end{array}$ & $\begin{array}{c}\text { Electricity } \\
\left(\$ / \mathrm{ft}^{2}\right)\end{array}$ & $\begin{array}{c}\text { Natural } \\
\text { Gas } \\
\left(\$ / \mathrm{ft}^{2}\right)\end{array}$ & $\begin{array}{c}\text { Total } \\
\left(\$ / \mathrm{ft}^{2}\right)\end{array}$ & $\begin{array}{l}\text { Savings } \\
\left(\$ / \mathrm{ft}^{2}\right)\end{array}$ & $\begin{array}{c}\text { Electricity } \\
\left(\$ / \mathrm{ft}^{2}\right)\end{array}$ & $\begin{array}{c}\text { Natural } \\
\text { Gas } \\
\left(\$ / \mathrm{ft}^{2}\right)\end{array}$ & $\begin{array}{c}\text { Total } \\
\left(\$ / \mathrm{ft}^{2}\right)\end{array}$ & $\begin{array}{r}\text { Savings } \\
\left(\$ / \mathrm{ft}^{2}\right)\end{array}$ \\
\hline 2A Houston, Texas & 1.59 & 0.02 & 1.61 & 1.54 & 0.01 & 1.56 & 0.05 & 1.47 & 0.01 & 1.48 & 0.13 \\
\hline 2B Phoenix, Arizona & 1.48 & 0.03 & 1.50 & 1.43 & 0.02 & 1.44 & 0.06 & 1.35 & 0.01 & 1.36 & 0.14 \\
\hline 3A Atlanta, Georgia & 1.46 & 0.06 & 1.52 & 1.41 & 0.04 & 1.46 & 0.06 & 1.34 & 0.03 & 1.37 & 0.15 \\
\hline 3B Las Vegas, Nevada & 1.39 & 0.04 & 1.43 & 1.35 & 0.03 & 1.37 & 0.06 & 1.28 & 0.02 & 1.29 & 0.14 \\
\hline 3C San Francisco, California & 1.33 & 0.03 & 1.36 & 1.29 & 0.02 & 1.31 & 0.05 & 1.23 & 0.01 & 1.24 & 0.12 \\
\hline 4A Baltimore, Maryland & 1.41 & 0.10 & 1.51 & 1.36 & 0.07 & 1.43 & 0.08 & 1.28 & 0.05 & 1.32 & 0.18 \\
\hline 5B Boulder, Colorado & 1.28 & 0.11 & 1.39 & 1.24 & 0.08 & 1.32 & 0.07 & 1.18 & 0.05 & 1.23 & 0.15 \\
\hline 6A Minneapolis, Minnesota & 1.24 & 0.18 & 1.42 & 1.21 & 0.14 & 1.35 & 0.07 & 1.16 & 0.10 & 1.27 & 0.15 \\
\hline
\end{tabular}


Table 34: Estimated Total Building Energy Cost - Medium Utility Rate

\begin{tabular}{|c|c|c|c|c|c|c|c|c|c|c|c|}
\hline \multirow{3}{*}{ Climate Zone } & \multicolumn{11}{|c|}{ Total Building Energy Cost (\$) - Medium Utility Rate } \\
\hline & \multicolumn{3}{|c|}{ Single-Pane Baseline } & \multicolumn{4}{|c|}{ Single-Pane Secondary } & \multicolumn{4}{|c|}{ Double-Pane Secondary } \\
\hline & $\begin{array}{c}\text { Electricity } \\
\text { (\$) }\end{array}$ & $\begin{array}{l}\text { Natural } \\
\text { Gas (\$) }\end{array}$ & Total (\$) & $\begin{array}{c}\text { Electricity } \\
\text { (\$) }\end{array}$ & $\begin{array}{c}\text { Natural } \\
\text { Gas (\$) }\end{array}$ & Total (\$) & $\begin{array}{l}\text { Savings } \\
\text { (\$) }\end{array}$ & $\begin{array}{c}\text { Electricity } \\
\text { (\$) }\end{array}$ & $\begin{array}{c}\text { Natural } \\
\text { Gas (\$) }\end{array}$ & Total (\$) & $\begin{array}{l}\text { Savings } \\
\text { (\$) }\end{array}$ \\
\hline 1A Miami, Florida & $1,131,958$ & 5,653 & $1,137,611$ & $1,104,139$ & 4,165 & $1,108,305$ & 29,307 & $1,053,820$ & 1,955 & $1,055,774$ & 81,837 \\
\hline 2A Houston, Texas & $1,147,268$ & 13,911 & $1,161,178$ & $1,113,413$ & 9,537 & $1,122,949$ & 38,229 & $1,060,948$ & 5,616 & $1,066,563$ & 94,615 \\
\hline 2B Phoenix, Arizona & $1,066,536$ & 17,166 & $1,083,702$ & $1,030,819$ & 11,930 & $1,042,749$ & 40,953 & 976,838 & 7,385 & 984,223 & 99,479 \\
\hline 3A Atlanta, Georgia & $1,056,778$ & 38,555 & $1,095,333$ & $1,021,599$ & 27,933 & $1,049,531$ & 45,801 & 967,598 & 19,468 & 987,066 & 108,267 \\
\hline 3B Las Vegas, Nevada & $1,005,114$ & 26,643 & $1,031,757$ & 971,996 & 17,942 & 989,938 & 41,819 & 922,468 & 11,414 & 933,882 & 97,875 \\
\hline 3C San Francisco, California & 958,676 & 19,956 & 978,632 & 932,134 & 13,552 & 945,686 & 32,946 & 888,087 & 7,037 & 895,124 & 83,508 \\
\hline 4A Baltimore, Maryland & $1,019,122$ & 66,311 & $1,085,432$ & 978,875 & 48,096 & $1,026,971$ & 58,462 & 921,047 & 33,261 & 954,308 & 131,125 \\
\hline 5A Chicago, Illinois & 881,350 & 90,874 & 972,225 & 860,316 & 67,520 & 927,837 & 44,388 & 823,948 & 47,642 & 871,590 & 100,635 \\
\hline 6A Minneapolis, Minnesota & 898,201 & 120,069 & $1,018,269$ & 876,580 & 91,915 & 968,495 & 49,774 & 841,144 & 69,806 & 910,950 & 107,319 \\
\hline
\end{tabular}


Table 35: Estimated Normalized Total Building Energy Cost - Medium Utility Rate

\begin{tabular}{|c|c|c|c|c|c|c|c|c|c|c|c|}
\hline \multirow{3}{*}{ Climate Zone } & \multicolumn{11}{|c|}{ Normalized Total Building Energy Cost (\$) - Medium Utility Rate } \\
\hline & \multicolumn{3}{|c|}{ Single-Pane Baseline } & \multicolumn{4}{|c|}{ Single-Pane Secondary } & \multicolumn{4}{|c|}{ Double-Pane Secondary } \\
\hline & $\begin{array}{c}\text { Electricity } \\
\left(\$ / \mathrm{ft}^{2}\right)\end{array}$ & $\begin{array}{c}\text { Natural } \\
\text { Gas } \\
\left(\$ / \mathrm{ft}^{2}\right)\end{array}$ & $\begin{array}{c}\text { Total } \\
\left(\$ / \mathrm{ft}^{2}\right)\end{array}$ & $\begin{array}{c}\text { Electricity } \\
\left(\$ / \mathrm{ft}^{2}\right)\end{array}$ & $\begin{array}{c}\text { Natural } \\
\text { Gas } \\
\left(\$ / \mathrm{ft}^{2}\right)\end{array}$ & $\begin{array}{c}\text { Total } \\
\left(\$ / \mathrm{ft}^{2}\right)\end{array}$ & $\begin{array}{l}\text { Savings } \\
\left(\$ / \mathrm{ft}^{2}\right)\end{array}$ & $\begin{array}{c}\text { Electricity } \\
\left(\$ / \mathrm{ft}^{2}\right)\end{array}$ & $\begin{array}{c}\text { Natural } \\
\text { Gas } \\
\left(\$ / \mathrm{ft}^{2}\right)\end{array}$ & $\begin{array}{c}\text { Total } \\
\left(\$ / \mathrm{ft}^{2}\right)\end{array}$ & $\begin{array}{l}\text { Savings } \\
\left(\$ / \mathrm{ft}^{2}\right)\end{array}$ \\
\hline 1A Miami, Florida & 2.27 & 0.01 & 2.28 & 2.21 & 0.01 & 2.22 & 0.06 & 2.11 & 0.00 & 2.12 & 0.16 \\
\hline 2A Houston, Texas & 2.30 & 0.03 & 2.33 & 2.23 & 0.02 & 2.25 & 0.08 & 2.13 & 0.01 & 2.14 & 0.19 \\
\hline 2B Phoenix, Arizona & 2.14 & 0.03 & 2.17 & 2.07 & 0.02 & 2.09 & 0.08 & 1.96 & 0.01 & 1.97 & 0.20 \\
\hline 3A Atlanta, Georgia & 2.12 & 0.08 & 2.20 & 2.05 & 0.06 & 2.11 & 0.09 & 1.94 & 0.04 & 1.98 & 0.22 \\
\hline 3B Las Vegas, Nevada & 2.02 & 0.05 & 2.07 & 1.95 & 0.04 & 1.99 & 0.08 & 1.85 & 0.02 & 1.87 & 0.20 \\
\hline 3C San Francisco, California & 1.92 & 0.04 & 1.96 & 1.87 & 0.03 & 1.90 & 0.07 & 1.78 & 0.01 & 1.80 & 0.17 \\
\hline 4A Baltimore, Maryland & 2.04 & 0.13 & 2.18 & 1.96 & 0.10 & 2.06 & 0.12 & 1.85 & 0.07 & 1.91 & 0.26 \\
\hline 5B Boulder, Colorado & 1.85 & 0.14 & 2.00 & 1.79 & 0.11 & 1.90 & 0.10 & 1.71 & 0.07 & 1.78 & 0.22 \\
\hline 6A Minneapolis, Minnesota & 1.80 & 0.24 & 2.04 & 1.76 & 0.18 & 1.94 & 0.10 & 1.69 & 0.14 & 1.83 & 0.22 \\
\hline
\end{tabular}


Table 36: Estimated Total Building Energy Cost - High Utility Rate

\begin{tabular}{|c|c|c|c|c|c|c|c|c|c|c|c|}
\hline \multirow{3}{*}{ Climate Zone } & \multicolumn{11}{|c|}{ Total Building Energy Cost (\$) - High Utility Rate } \\
\hline & \multicolumn{3}{|c|}{ Single-Pane Baseline } & \multicolumn{4}{|c|}{ Single-Pane Secondary } & \multicolumn{4}{|c|}{ Double-Pane Secondary } \\
\hline & $\begin{array}{c}\text { Electricity } \\
\text { (\$) }\end{array}$ & $\begin{array}{l}\text { Natural } \\
\text { Gas (\$) }\end{array}$ & Total (\$) & $\begin{array}{c}\text { Electricity } \\
\text { (\$) }\end{array}$ & $\begin{array}{c}\text { Natural } \\
\text { Gas (\$) }\end{array}$ & Total (\$) & $\begin{array}{c}\text { Savings } \\
\text { (\$) }\end{array}$ & $\begin{array}{c}\text { Electricity } \\
\text { (\$) }\end{array}$ & $\begin{array}{c}\text { Natural } \\
\text { Gas (\$) }\end{array}$ & Total (\$) & $\begin{array}{c}\text { Savings } \\
\text { (\$) }\end{array}$ \\
\hline 1A Miami, Florida & $1,803,119$ & 7,989 & $1,811,109$ & $1,758,806$ & 5,887 & $1,764,693$ & 46,416 & 1,678,651 & 2,762 & $1,681,413$ & 129,696 \\
\hline 2B Phoenix, Arizona & $1,698,907$ & 24,259 & $1,723,166$ & $1,642,012$ & 16,861 & $1,658,873$ & 64,294 & $1,556,025$ & 10,437 & $1,566,462$ & 156,704 \\
\hline 3A Atlanta, Georgia & $1,683,364$ & 54,487 & $1,737,850$ & $1,627,325$ & 39,476 & $1,666,801$ & 71,049 & $1,541,307$ & 27,513 & $1,568,820$ & 169,030 \\
\hline 3B Las Vegas, Nevada & $1,601,066$ & 37,654 & $1,638,720$ & $1,548,312$ & 25,357 & $1,573,669$ & 65,051 & $1,469,419$ & 16,130 & $1,485,549$ & 153,171 \\
\hline 3C San Francisco, California & $1,527,094$ & 28,203 & $1,555,297$ & $1,484,815$ & 19,153 & $1,503,968$ & 51,329 & $1,414,652$ & 9,945 & $1,424,597$ & 130,700 \\
\hline 4A Baltimore, Maryland & $1,623,380$ & 93,712 & $1,717,093$ & $1,559,270$ & 67,970 & $1,627,241$ & 89,852 & $1,467,154$ & 47,005 & $1,514,160$ & 202,933 \\
\hline 5A Chicago, Illinois & $1,403,921$ & 128,427 & $1,532,348$ & $1,370,415$ & 95,422 & $1,465,838$ & 66,510 & $1,312,483$ & 67,329 & $1,379,813$ & 152,535 \\
\hline 6A Minneapolis, Minnesota & $1,430,762$ & 169,685 & $1,600,448$ & $1,396,322$ & 129,898 & $1,526,220$ & 74,228 & $1,339,875$ & 98,653 & $1,438,528$ & 161,919 \\
\hline
\end{tabular}


Table 37: Estimated Normalized Total Building Energy Cost - High Utility Rate

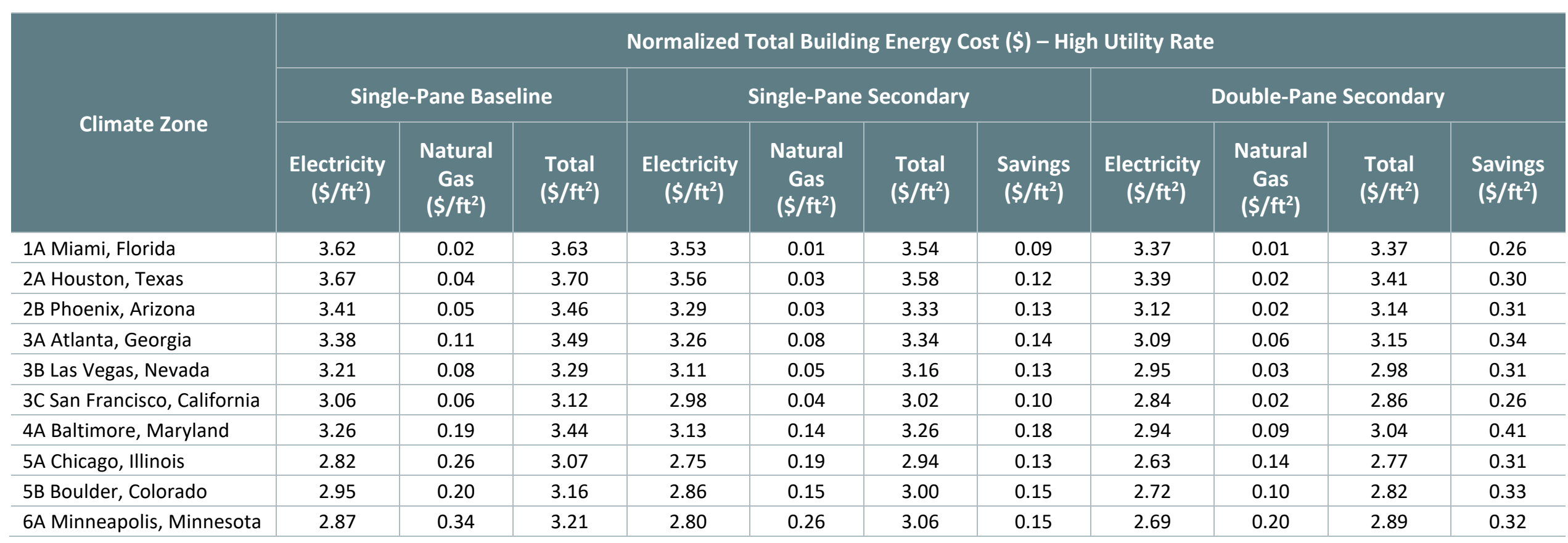


Table 38: Estimated Simple Payback and Savings-to-Investment Ratio

\begin{tabular}{|c|c|c|c|c|c|c|c|c|c|c|c|c|}
\hline \multirow{3}{*}{ Climate Zone } & \multicolumn{4}{|c|}{ Low Utility Rate } & \multicolumn{4}{|c|}{ Medium Utility Rate } & \multicolumn{4}{|c|}{ High Utility Rate } \\
\hline & \multicolumn{2}{|c|}{$\begin{array}{l}\text { Single-Pane } \\
\text { Secondary }\end{array}$} & \multicolumn{2}{|c|}{$\begin{array}{l}\text { Double-Pane } \\
\text { Secondary }\end{array}$} & \multicolumn{2}{|c|}{$\begin{array}{l}\text { Single-Pane } \\
\text { Secondary }\end{array}$} & \multicolumn{2}{|c|}{$\begin{array}{l}\text { Double-Pane } \\
\text { Secondary }\end{array}$} & \multicolumn{2}{|c|}{$\begin{array}{l}\text { Single-Pane } \\
\text { Secondary }\end{array}$} & \multicolumn{2}{|c|}{$\begin{array}{l}\text { Double-Pane } \\
\text { Secondary }\end{array}$} \\
\hline & $\begin{array}{c}\text { Payback } \\
\text { (yr) }\end{array}$ & SIR & $\begin{array}{c}\text { Payback } \\
\text { (yr) }\end{array}$ & SIR & $\begin{array}{c}\text { Payback } \\
\text { (yr) }\end{array}$ & SIR & $\begin{array}{c}\text { Payback } \\
\text { (yr) }\end{array}$ & SIR & $\begin{array}{c}\text { Payback } \\
\text { (yr) }\end{array}$ & SIR & $\begin{array}{l}\text { Payback } \\
\text { (yr) }\end{array}$ & SIR \\
\hline 2A Houston, Texas & 34.0 & 0.6 & 17.6 & 1.1 & 23.7 & 0.8 & 12.2 & 1.6 & 15.1 & 1.3 & 7.7 & 2.6 \\
\hline 2B Phoenix, Arizona & 31.7 & 0.6 & 16.7 & 1.2 & 22.1 & 0.9 & 11.6 & 1.7 & 14.1 & 1.4 & 7.4 & 2.7 \\
\hline 3A Atlanta, Georgia & 28.1 & 0.7 & 15.3 & 1.3 & 19.8 & 1.0 & 10.7 & 1.9 & 12.7 & 1.6 & 6.8 & 2.9 \\
\hline 3B Las Vegas, Nevada & 30.9 & 0.6 & 16.9 & 1.2 & 21.7 & 0.9 & 11.8 & 1.7 & 13.9 & 1.4 & 7.5 & 2.7 \\
\hline 3C San Francisco, California & 39.2 & 0.5 & 19.8 & 1.0 & 27.5 & 0.7 & 13.8 & 1.4 & 17.6 & 1.1 & 8.8 & 2.3 \\
\hline 4A Baltimore, Maryland & 21.9 & 0.9 & 12.5 & 1.6 & 15.5 & 1.3 & 8.8 & 2.3 & 10.1 & 2.0 & 5.7 & 3.5 \\
\hline 5B Boulder, Colorado & 25.7 & 0.8 & 15.1 & 1.3 & 18.3 & 1.1 & 10.7 & 1.9 & 12.0 & 1.7 & 7.0 & 2.9 \\
\hline 6A Minneapolis, Minnesota & 25.3 & 0.8 & 15.1 & 1.3 & 18.2 & 1.1 & 10.8 & 1.9 & 12.2 & 1.6 & 7.1 & 2.8 \\
\hline
\end{tabular}


Additional analysis was conducted to investigate if the single-pane secondary window with low SHGC (0.2), which could be offered by the manufacturer, could provide a good economic return in a warm climate zone (Climate Zone 1A) when compared to a double-pane secondary window with the same SHGC. The results presented in Table 39 show that the single-pane secondary window with low SHGC has lower payback and higher SIR than a double-pane secondary window at the same SHGC for Climate Zone 1A.

Table 39: Energy Savings of Single-Pane and Double-Pane Secondary Windows with Low SHGC for Climate Zone 1

\begin{tabular}{l|c|c} 
& $\begin{array}{l}\text { Single-Pane } \\
\text { Secondary }\end{array}$ & $\begin{array}{l}\text { Double- } \\
\text { Pane } \\
\text { Secondary }\end{array}$ \\
\hline $\begin{array}{l}\text { Energy Savings } \\
\text { (kBtu) }\end{array}$ & $3,659,683$ & $3,580,465$ \\
\hline $\begin{array}{l}\text { Energy Cost Savings } \\
\text { (\$) }\end{array}$ & 107,657 & 104,935 \\
\hline Payback (yr) & 8.41 & 11.01 \\
\hline SIR & 2.38 & 1.82 \\
\hline
\end{tabular}




\section{Summary Findings and Conclusions}

This demonstration assessed the use of secondary windows for GSA applications. Several different evaluation criteria were used to assess the viability of secondary windows for GSA applications. Some of these assessments were performed with models, while others required onsite evaluations including time series measurements.

The secondary windows operated as intended and most evaluation criteria were met. The secondary windows can provide energy savings and can be cost effective due to improved thermal performance as compared to existing single-pane windows. Summary of results, findings and conclusions are outlined below.

- Secondary windows can be quickly and easily installed with existing windows to provide a cost-effective and efficient way to improve thermal performance and occupant comfort, especially for integration with existing single-pane windows.

- Secondary windows can be a substantially less expensive alternative to replacing primary windows. In addition, the secondary windows are lightweight and thus suitable for structures that cannot handle additional weight.

- The technology is particularly useful in buildings or areas where planning permission rules do not allow any aesthetic changes whatsoever to the external primary windows (e.g., historic buildings).

- Windows with the same U-value are manufactured with various levels of SHGC. SHGC should be appropriately selected for a climate zone. The lower the SHGC, the less solar heat it transmits and the greater its shading ability. A product with a high SHGC rating is more effective at collecting solar heat during the winter. A product with a low SHGC rating is more effective at reducing cooling loads during the summer by blocking heat gain from the sun.

- The calculated CR rating for the secondary window integrated with baseline single-pane window is 4446 , falling short of the criteria by a narrow margin. This may not necessarily be due to the secondary window, but rather to the existing single-pane window. Note: A window with a CR rating over 50 is considered to have good CR.

- The thermal comfort criteria are met as the results show that the majority of the indoor conditions were within the comfort boundary. However, the PMV and PPD analysis shows that the space in Building 53 was slightly cool and predicts that $45 \%$ of the occupants could experience local thermal discomfort. Thermal discomfort possibly already existed and may be caused by HVAC operation rather than the windows.

- Measured temperatures at the center of the glass during the coldest period show significant improvement with the secondary window. The average temperatures at the center of the glass of the double-pane and single-pane secondary windows during cold period (mean outdoor temperature at $21^{\circ} \mathrm{F}$ ) are $68.2^{\circ} \mathrm{F}$ and $56.7^{\circ} \mathrm{F}$, respectively, compared to the baselined single-pane window temperature of $48^{\circ} \mathrm{F}$. Temperature differences increase radiant asymmetry, which contributes to occupant discomfort. ASHRAE 55 guidelines state that for vertical surfaces, radiant asymmetry should be kept to less than $18^{\circ} \mathrm{F}$. In this circumstance, the vertical surface radiant asymmetry of the double-pane and single-pane secondary windows are within the ASHRAE guidelines. In addition, larger temperature differences between the window surface and indoor air can also induce convective heat transfer through air movement, particularly during cold conditions. Drafts caused by the air movement can also contribute to occupant discomfort. 
- Most thermal comfort survey responses were positive and recommended the secondary window retrofit in the future. The secondary windows' appearance was noticeable but acceptable.

- To evaluate the deployment potential, energy savings and economic analyses were conducted for ten ASHRAE climate zones. The energy cost was estimated for three levels of GSA utility rates (low, medium, and high). The criteria were a payback period of less than 15 years and a SIR greater than 1 for both secondary windows. The results show that the double-pane secondary window is cost effective for most climate zones and at medium and high utility rates.

- For cold climates, the double-pane secondary window outperformed the single-pane secondary window and is broadly recommended. For warm climates, a single-pane secondary window with low SHGC is more cost effective. 


\section{References}

1. Apte, J. and D. Arasteh. 2006. Window-Related Energy Consumption in the US Residential and Commercial Building Stock. Berkeley, CA: Lawrence Berkeley National Laboratory. https://facades.lbl.gov/publications/window-related-energy-consumption-us.

2. ASHRAE. 2020. ANSI/ASHRAE Addendum d to ANSI/ASHRAE Standard 55-2017 Thermal Environmental Conditions for Human Occupancy. https://www.ashrae.org/file\%20library/technical\%20resources/standards\%20and\%20guidelines/standards\%20a ddenda/55 2017 d 20200731.pdf.

3. Curcija C., Goudey H., and Mitchell, R. 2017. "Low-e Applied Film Window Retrofit for Insulation and Solar Control."

4. Curcija C., Goudey H., Mitchell R., and Dickerhoff E. 2013. "Highly Insulating Window Panel Attachment Retrofit."

5. Deru M., Field K. Studer D., Benne K., Griffin B., and Torcellini P. "U.S. Department of Energy Commercial Reference Building Models of the National Building Stock."

6. Desjarlais, A.O., K.W. Child, and J.E. Christian. 1998. "To storm or not to storm: measurement method to quantify impact of exterior envelope airtightness on energy usage prior to construction."

7. Drumheller, S.C., C. Kohler, and S. Minen. 2007. "Field Evaluation of Low-E Storm Windows."

8. Fernandes L., Lee E., and Thanachareonkit, A. 2015. "Electrochromic Window Demonstration at the Donna Land Port of Entry."

9. General Services Administration. 2013. "Hi-R Low-e Window Retrofit System."

10. General Services Administration. 2014. "Electrochromic and Thermochromic Windows."

11. General Services Administration. 2016. "Denver Federal Center Long-term Space Strategic Plan."

12. Gowri, K., D. Winiarski, and R. Jarnagin. 2009. "Infiltration Modeling Guidelines for Commercial Building Energy Analysis." Bothell, WA: Pacific Northwest National Laboratory. https://www.pnnl.gov/main/publications/external/technical reports/PNNL-18898.pdf

13. Huizenga, C. 1999. "Window Performance for Human Thermal Comfort." Berkeley, CA: Lawrence Berkeley National Laboratory. https://gaia.lbl.gov/btech/papers/44032.pdf

14. Lee E., Fernandes L., Goudey H., Johnsson C., Curcija C., Pang X., DiBartolomeo D., and Hoffmann S. 2014. "A Pilot Demonstration of Electrochromic and Thermochromic Windows in the Denver Federal Center, Building 41, Denver, Colorado."

15. Lee E., Fernandes L., Touzani S., Thanachareonkit A., Pang X., and Dickerhoff D. 2016. "Electrochromic Window Demonstration at the 911 Federal Building, 911 Northeast 11th Avenue, Portland, Oregon."

16. U.S. Energy Information Administration. 2018. "Updated Buildings Sector Appliance and Equipment Costs and Efficiencies."

17. U.S. Department of Energy. 2019a. Better Buildings, Envelope Technology Research Team Webinar, Energy Savings Impact of Airtightness in U.S. Commercial Buildings, January 29, 2019. https://betterbuildingssolutioncenter.energy.gov/sites/default/files/slides/ETRT\%20Jan\%202019 ALL\%20Slides. pdf 
18. U.S. Department of Energy. 2019b. Better Buildings Residential Network Peer Exchange Call Series: Window Treatments: The Undervalued, Highly Efficient Energy Efficiency Measure, November 14, 2019. https://www.energy.gov/sites/prod/files/2019/12/f69/bbrn-window-treatments-111419.pdf

\section{WEBSITES}

1. Alpen High Performance Products, https://thinkalpen.com/

2. Center for The Built Environment Thermal Comfort Tool, https://comfort.cbe.berkeley.edu/

3. DOE EnergyPlus, https://energyplus.net/

4. Lawrence Berkeley Laboratory THERM, https://windows.Ibl.gov/software/therm

5. Lawrence Berkeley Laboratory WINDOW, https://windows.lbl.gov/software/window

6. OpenStudio, https://www.openstudio.net/

7. Minnesota Sustainable Housing Initiative, http://www.mnshi.umn.edu/kb/scale/condensationresistance.html

8. What is PMV and PPD? https://www.simscale.com/blog/2019/09/what-is-pmv-ppd/

9. Reading the AERC Energy Performance Certificate, https://aercenergyrating.org/reading-the-commercial-label/ 


\section{Appendix A - Details of Secondary Windows}

\section{Single-pane secondary window}

Frame: Low profile, long strand, pultruded fiberglass with foam insulation

Glass: Alpen ThinGlass (single pane) with applied safety film

\section{Double-pane secondary window}

Frame: Low profile, long strand, pultruded fiberglass with foam insulation

Glass: Micro IG unit - one pane of ThinGlass with applied safety film, and one pane of 1/8" Cardinal 366

Spacer: Warm edge

Gas: Krypton

Table 40: Performance Data for Single-Pane and Double-Pane Secondary Window

\begin{tabular}{|l|c|}
\hline \multicolumn{1}{|c|}{ DATA } & $\begin{array}{c}\text { Existing } \\
1 / 4^{" ~ c l e a r}\end{array}$ \\
\hline R-value (center of glass) & 0.97 \\
\hline Winter u-value (center of glass) & 1.03 \\
\hline SHGC & 0.82 \\
\hline SC & 0.84 \\
\hline Tvis & $88 \%$ \\
\hline
\end{tabular}

\begin{tabular}{|c|c|c|c|}
\hline $\begin{array}{c}\text { Single-pane } \\
\text { Secondary }\end{array}$ & $\begin{array}{c}\text { Double-pane } \\
\text { Secondary } \\
(180-K-1 \mathrm{~mm})\end{array}$ & $\begin{array}{c}\text { Double-pane } \\
\text { Secondary } \\
(272-K-1 \mathrm{~mm})\end{array}$ & $\begin{array}{c}\text { Double pane } \\
\text { Secondary } \\
(366-\mathrm{K}-\mathrm{mm})\end{array}$ \\
\hline 2.1 & 5.6 & 5.9 & 6.3 \\
\hline 0.48 & 0.18 & 0.17 & 0.16 \\
\hline 0.73 & 0.58 & 0.45 & 0.36 \\
\hline 0.84 & 0.67 & 0.52 & 0.41 \\
\hline $81 \%$ & $72 \%$ & $65 \%$ & $58 \%$ \\
\hline
\end{tabular}




\section{Appendix B - Secondary Window Weight Comparison}

Manufacturer-provided weight data for single-pane, single-pane secondary, double-pane, and double-pane secondary windows are presented in Table 41 and Table 42.

Table 41: Single-Pane Window Versus Single-Pane Secondary Window Weight Difference

\begin{tabular}{|c|c|c|c|c|c|c|c|c|}
\hline \multirow{2}{*}{ Size } & \multirow{2}{*}{$\begin{array}{c}\text { Area } \\
\left(\mathrm{ft}^{2}\right)\end{array}$} & \multicolumn{2}{|c|}{ Configuration } & \multicolumn{2}{|c|}{$\begin{array}{l}\text { Single-Pane } \\
\text { Secondary }\end{array}$} & \multicolumn{2}{|c|}{$\begin{array}{l}\text { Single-Pane } \\
\text { Window }\end{array}$} & \multirow{2}{*}{$\begin{array}{c}\text { Single-Pane } \\
\text { Window vs. } \\
\text { Single-Pane } \\
\text { Secondary } \\
\text { Weight } \\
\text { Difference }\end{array}$} \\
\hline & & $\begin{array}{l}\text { Width } \\
\text { (in) }\end{array}$ & $\begin{array}{l}\text { Length } \\
\text { (in) }\end{array}$ & $\begin{array}{c}\text { Total } \\
\text { Weight } \\
\text { (Ib) }\end{array}$ & $\mathrm{lb} / \mathrm{ft}^{2}$ & $\begin{array}{c}\text { Total } \\
\text { Weight } \\
\text { (lb) }\end{array}$ & $\mathrm{lb} / \mathrm{ft}^{2}$ & \\
\hline Small & 10 & 30 & 48 & 12.3 & 1.2 & 36.3 & 3.6 & $2.95 x$ \\
\hline Medium & 20 & 48 & 60 & 20.2 & 1.0 & 68.8 & 3.4 & $2.81 x$ \\
\hline Large & 32 & 48 & 96 & 29.7 & 0.9 & 107.2 & 3.0 & $3.19 x$ \\
\hline Building 53 & 16.3 & 48.5 & 48.5 & 17.3 & 1.1 & 56.9 & 3.3 & $3.1 x$ \\
\hline
\end{tabular}

Table 42: Double-Pane Window Versus Double-Pane Secondary Window Weight Difference

\begin{tabular}{|c|c|c|c|c|c|c|c|c|}
\hline \multirow{2}{*}{ Size } & \multirow{2}{*}{$\begin{array}{c}\text { Area } \\
\left(\mathrm{ft}^{2}\right)\end{array}$} & \multicolumn{2}{|c|}{ Configuration } & \multicolumn{2}{|c|}{$\begin{array}{l}\text { Double-Pane } \\
\text { Secondary }\end{array}$} & \multicolumn{2}{|c|}{$\begin{array}{l}\text { Double Pane } \\
\text { Window }\end{array}$} & \multirow{2}{*}{$\begin{array}{l}\text { Double-pane } \\
\text { Window vs. } \\
\text { Double-Pane } \\
\text { Secondary } \\
\text { Weight Difference }\end{array}$} \\
\hline & & $\begin{array}{l}\text { Width } \\
\text { (in) }\end{array}$ & $\begin{array}{l}\text { Length } \\
\text { (in) }\end{array}$ & $\begin{array}{c}\text { Total } \\
\text { Weight } \\
\text { (lb) }\end{array}$ & $\mathrm{lb} / \mathrm{ft}^{2}$ & $\begin{array}{c}\text { Total } \\
\text { Weight } \\
\text { (lb) }\end{array}$ & $\mathrm{lb} / \mathrm{ft}^{2}$ & \\
\hline Small & 10 & 30 & 48 & 26.8 & 2.7 & 63.9 & 6.4 & $2.38 x$ \\
\hline Medium & 20 & 48 & 60 & 50.4 & 2.5 & 125.5 & 6.3 & $2.48 x$ \\
\hline Large & 32 & 48 & 96 & 103.3 & 3.2 & 199.1 & 6.2 & $1.96 x$ \\
\hline Building 53 & 16.3 & 48.5 & 48.5 & 41.8 & 2.6 & 102.9 & 6.3 & $2.46 x$ \\
\hline
\end{tabular}




\section{Appendix C - AERC Air Leakage Testing Results of Single- and Double-Pane Secondary Windows}

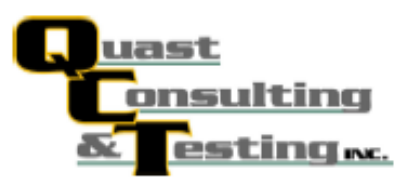

AERC 1.2 Air Leakage

Performance Test Report

Rendered To:

Alpen

Report No::

QCT21-6427.01

Series/Product:

WinSert

Interior Secondary Insert

Test Date(s):

August 27, 2021 through September 2, 2021

Report Date:

September 2, 2021 
QCT21-6427.01

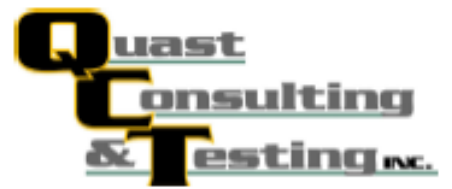
Report Date: $\quad 09 / 02 / 21$
Test Dates: $\quad 08 / 27 / 21$
Through: $\quad 09 / 02 / 21$

\section{MANUFACTURER: Alpen \\ 335-A Centenial Parkway \\ Louisville, CO 80027 \\ SERIES/MODEL: WinSert \\ PRODUCT TYPE: Interior Secondary Insert}

\begin{tabular}{|c|c|}
\hline \multicolumn{2}{|c|}{ Summary of Results } \\
\hline Test Procedure/Standard & Details \\
\hline AERC 1.2 Air Leakage - WinSert Plus & $0.3 \mathrm{~L} / \mathrm{s} / \mathrm{m}^{2}\left(0.06 \mathrm{cfm} / \mathrm{ft}^{2}\right) @ 75 \mathrm{~Pa}(1.57 \mathrm{psf})$, PASS \\
\hline AERC 1.2 Air Leakage - WinSert Lite & $0.3 \mathrm{~L} / \mathrm{s} / \mathrm{m}^{2}\left(0.06 \mathrm{cfm} / \mathrm{ft}^{2}\right) @ 75 \mathrm{~Pa}(1.57 \mathrm{psf})$, PASS \\
\hline
\end{tabular}

Reference Report No. QCT21-6427.01 for complete specimen description and test results. 
QCT21-6427.01

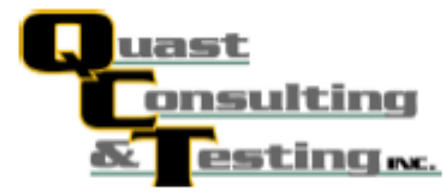
Report Date: $\quad 09 / 02 / 21$
Test Dates: $\quad 08 / 27 / 21$
Through: $\quad 09 / 02 / 21$

\section{Project Summary:}

Quast Consulting and Testing, Inc. was contracted by Alpen to perform testing per AERC 1.2 Air Leakage on a WinSert Interior Secondary Insert. The specimen was supplied by Alpen and was tested at Quast Consulting and Testing laboratory located in Mosinee, WI. Test specimen description and test results are reported herein.

Procedure:

Testing and reporting were conducted in accordance with:

\begin{tabular}{|l|l|}
\hline AERC 1.2 & $\begin{array}{l}\text { Physical Test Methods for Measureing Energy Performance Properties of } \\
\text { Fenestration Products - Air Leakage }\end{array}$ \\
\hline ASTM E283-19 & $\begin{array}{l}\text { Standard Test Method for Determining Rate of Air Leakage Through Exterior } \\
\text { Windows, Curtain Walls, and Doors Under Specified Pressure Differences } \\
\text { Across the Specimen }\end{array}$ \\
\hline
\end{tabular}

\section{Test Specimen Description:}

Series/Model:

Product Type:

Overall Size:

Overall Area:
WinSert

Interior Secondary Insert

$1194 \mathrm{~mm}$ (47.00 in) wide x $1492 \mathrm{~mm}$ (58.75 in) high

$1.78 \mathrm{~m}^{2}\left(19.17 \mathrm{ft}^{2}\right)$

\section{Frame Construction:}

Fiberglass with mitered corner construction.

Weatherstripping Type:

Quantity Location

\begin{tabular}{|l|c|l|}
\hline \hline Foam Filled Bulb & 2 & Continuous row at perimeter of frame. \\
\hline
\end{tabular}

\section{Installation:}

Insert window was installed into a test buck fitted with calibration panel. The rough opening of the test buck was $1200 \mathrm{~mm}$ wide by $1500 \mathrm{~mm}$ tall. The insert window was held in place with 4 temporary retaining clips. The insert window was installed on the inboard side of the calibration panel at a distance of 1.5 " from the surface of the calibration panel. 
QCT21-6427.01

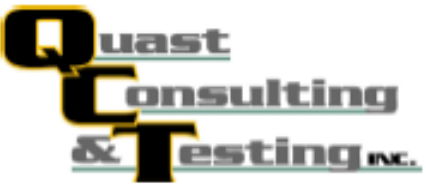

$\begin{aligned} \text { Report Date: } & 09 / 02 / 21 \\ \text { Test Dates: } & 08 / 27 / 21 \\ \text { Through: } & 09 / 02 / 21\end{aligned}$

Test Results:

$\underline{\text { Title of Test }}$

$\underline{\text { Results }}$

Air Infiltration/Exfiltration per ASTM E283-19

Calibration Panel Measured Leakage

$2.0 \mathrm{cfm} / \mathrm{ft}^{2}$

$10.2 \mathrm{~L} / \mathrm{s} / \mathrm{m}^{2}$

\author{
WinSert Plus - Dual Glazed \\ Infiltration \\ $75 \mathrm{~Pa}$ \\ $1.57 \mathrm{psf}$
}

$0.3 \mathrm{~L} / \mathrm{s} / \mathrm{m}^{2}$

$0.06 \mathrm{cfm} / \mathrm{ft}^{2}$

WinSert Lite - Single Glazed
Infiltration
$75 \mathrm{~Pa}$
$1.57 \mathrm{psf}$

$0.3 \mathrm{~L} / \mathrm{s} / \mathrm{m}^{2}$

$0.06 \mathrm{cfm} / \mathrm{ft}^{2}$

Page 3 of 4 
QCT21-6427.01

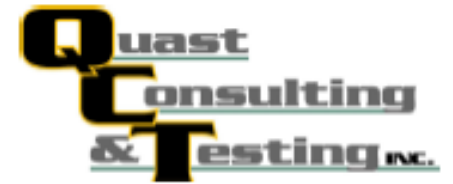
Report Date: $\quad 09 / 02 / 21$
Test Dates: $\quad 08 / 27 / 21$
Through: $\quad 09 / 02 / 21$

Test specimen drawings have been reviewed by Quast Consulting and Testing, Inc. and are representative of the test specimen reported herein. Material compositions were supplied by the manufacturer and were not verified by QCT.

\section{List of Official Observers:}

\author{
Name: \\ Brian Sasman \\ Kelly Marlow
}

\author{
Company: \\ Quast Consulting and Testing, Inc. \\ Quast Consulting and Testing, Inc.
}

The reported results were secured using the designated test methods. Test results relate only to the specimen tested. Statements of conformity are determined using the simple acceptance decision rule per ILAC-G8:09-2019. This report does not constitute certification of this product nor an opinion or endorsement by this laboratory. This report is the exclusive property of the client so named herein and may not be reproduced, except in full, without the written approval of Quast Consulting and Testing, Inc.

Electronic records of data sheets, drawings, correspondence, this report, or other pertinent project documentation will be retained for a period of 10 years from the test completion date. Physical representative samples of the test specimen will be retained for a period of 2 years from the test completion date. At the end of this retention period, such material shall be discarded without notice and the service life of this report will expire.

QUAST CONSULTING \& TESTING, INC.

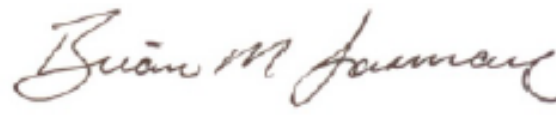

Brian M. Sasman, P.E.

Author
QUAST CONSULTING \& TESTING, INC.

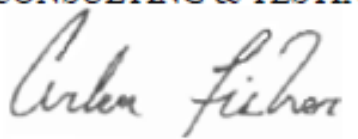

Arlen Fisher, P.E.

Reviewer

Attachments: This report is complete only when all attachments listed are included.

Appendix A: As-Built Drawings (2 Pages) 


\section{Appendix D - Infrared Thermography Field Measurements}

The main purpose of taking IR images of secondary windows as part of the study was to quantify the thermal gradient near the edge of glass. For overall monitoring, most thermocouples were attached to the glass and frame, but only one or two thermocouples were attached near the edge of glass for each monitored window. These point measurements are useful for comparison to thermal models. The IR images can provide pixel-bypixel temperature measurements in a location where the temperature changes significantly in a small distance.

Figure 22 shows an IR image (left) of the two windows that were instrumented with thermocouples and the visual photo (right) of the same location. They were taken from the outside before sunrise on a cold morning. Figure 23 shows the IR image and visual photo taken of one of the same windows from the inside. The window frame appeared as a colder surface than the glass. In addition, reflections of people in the room near the window can be seen on the IR image. Most glass is specularly reflective in the IR; therefore, it is not as simple as one might imagine to measure glass temperature with an IR camera.

A strip of blue masking tape was adhered to the glass and frame as shown in Figure 24. It provides a surface that is not reflective and does not change the temperature of the glass very much. Figure 25 shows that surface temperature varied by almost $10^{\circ} \mathrm{F}$ over a small distance from the glass to the frame edge.

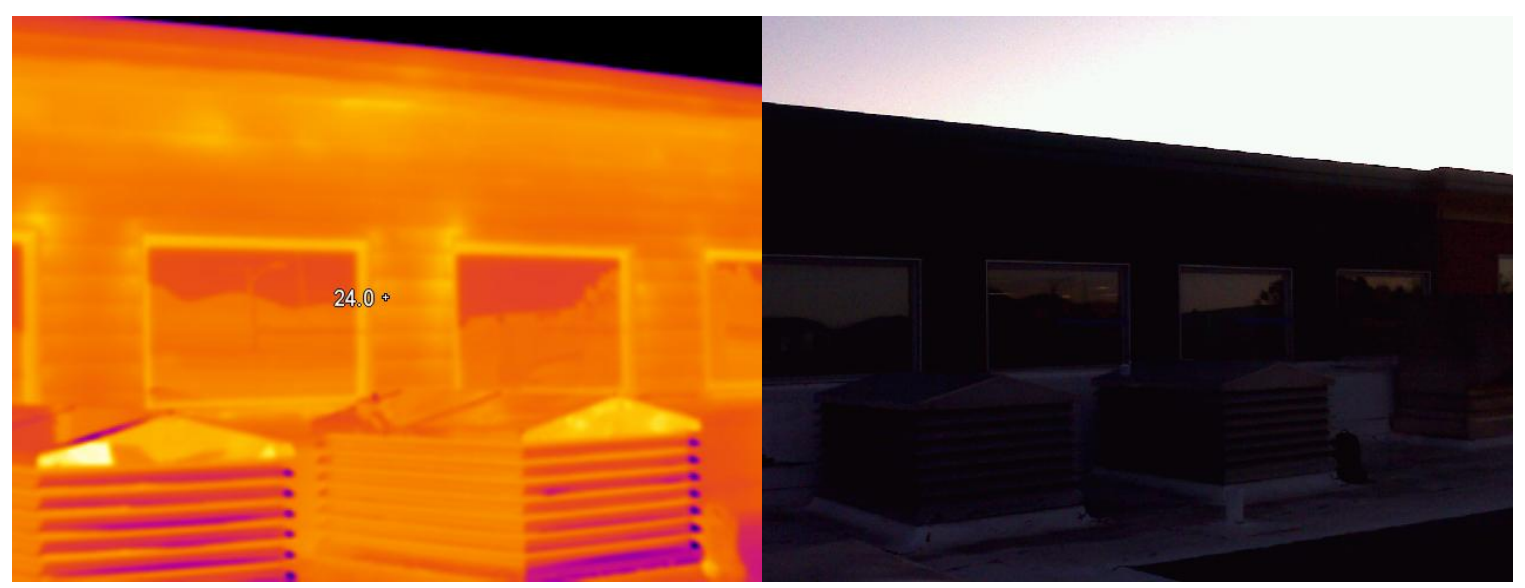

Figure 22: IR image (left) of the two windows outside and the visual photo (right) of the same location 


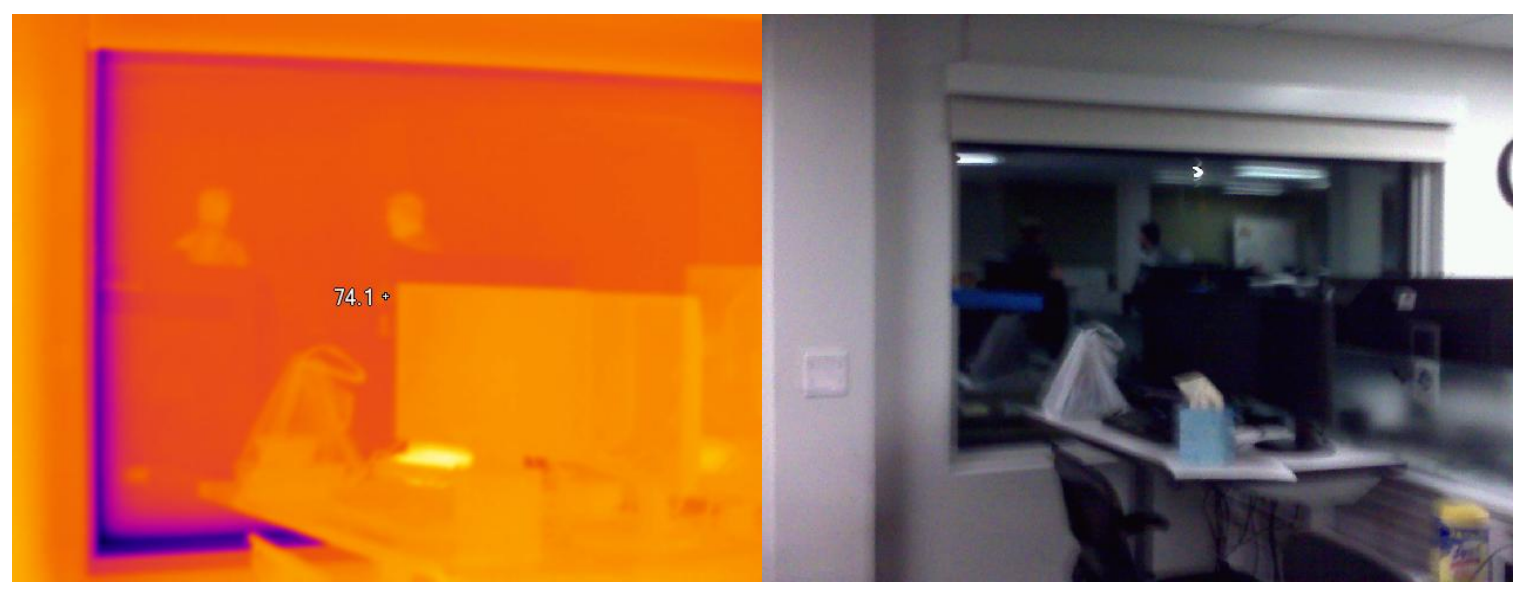

Figure 23: IR image (left) of the two windows inside and the visual photo (right) of the same location

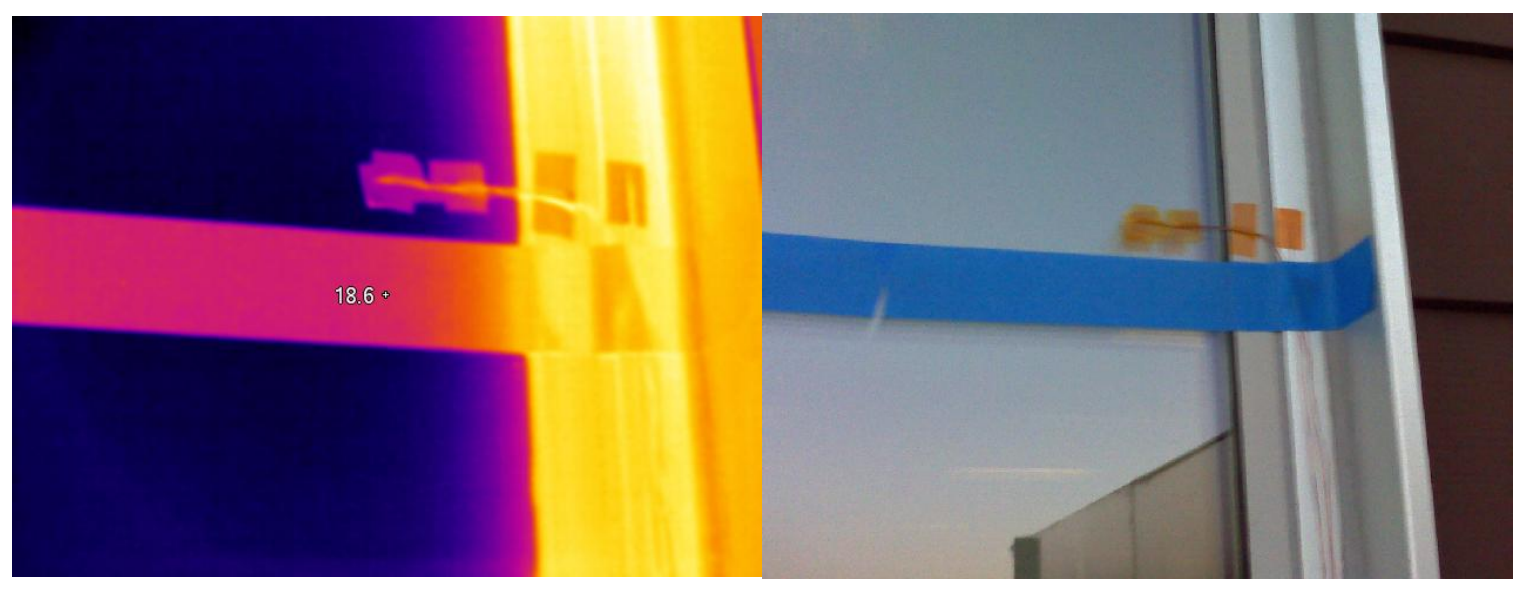

Figure 24: Thermocouples for temperature measurement on glass and frame 


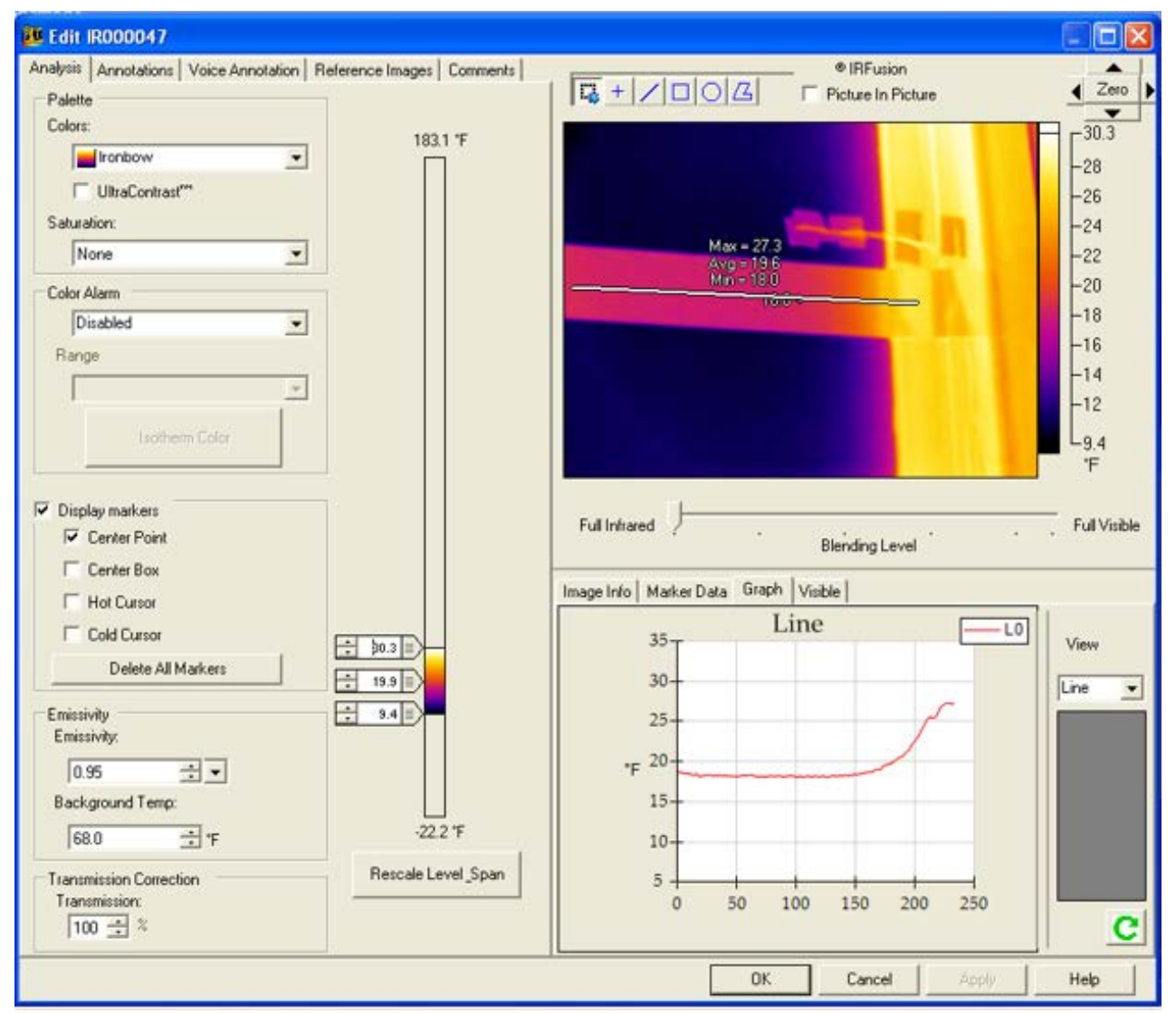

Figure 25: Surface temperature from the glass to the frame edge 


\section{Appendix E - EnergyPlus Modeling Assumptions}

Table 43 summarizes the building characteristics of the DOE Commercial Reference Building Model for a large office. Three levels of GSA utility rates were used for economic and deployment potential analysis for the technology.

\section{Table 43: Summary of EnergyPlus Model for Large Office}

\begin{tabular}{|c|c|c|}
\hline \multicolumn{3}{|c|}{ Large Office, 1980-2004 Vintage } \\
\hline & Weather Data & Climate Zone 5B \\
\hline & Building Type & Large office \\
\hline & $\begin{array}{l}\text { Total Number of Buildings } \\
\text { Modeled }\end{array}$ & 1 \\
\hline & Building Areas & $498,588 \mathrm{ft}^{2}$ \\
\hline & Above-Grade Floors & 12 \\
\hline \multirow{6}{*}{ Building Footprint } & Building Orientation & Plan North \\
\hline & Zoning Pattern & Perimeter and core zones \\
\hline & Perimeter Zone Depth & $30 \mathrm{ft}$ \\
\hline & Floor to Floor Height & $14 \mathrm{ft}$ \\
\hline & Floor to Ceiling Height & $10 \mathrm{ft}$ \\
\hline & Roof Pitch & $0^{\circ}$, flat roof \\
\hline \multirow{3}{*}{ Roof } & Construction & Typical insulation entirely above deck roof \\
\hline & Roof & \\
\hline & Insulation & $\mathrm{R}-18.83$ \\
\hline \multirow{2}{*}{ Walls } & Construction & Typical insulated steel framed exterior wall \\
\hline & Exterior Insulation & Effective R-6.29 \\
\hline Exterior Doors & Door Type & Typical insulated metal door \\
\hline Exterior Windows & Window Type & Single pane window (baseline) \\
\hline $\begin{array}{l}\text { Window to Wall } \\
\text { Ratio }\end{array}$ & Gross Window-Wall Ratio & $38.05 \%$ \\
\hline $\begin{array}{l}\text { Building } \\
\text { Operation }\end{array}$ & Schedule & $\begin{array}{l}7 \text { a.m. to } 5 \text { p.m., Mon-Fri; closed on the } \\
\text { weekends }\end{array}$ \\
\hline \multirow[t]{2}{*}{ Power Density } & Lighting & $1.50 \mathrm{~W} / \mathrm{ft}^{2}$ \\
\hline & Plug Loads & $1.0 \mathrm{~W} / \mathrm{ft}^{2}$ \\
\hline HVAC Systems & System Type & $\begin{array}{l}\text { Variable air volume system with hot water } \\
\text { reheat }\end{array}$ \\
\hline
\end{tabular}


Large Office, 1980-2004 Vintage

\begin{tabular}{l|l|l} 
& Cooling System & Chilled water, chillers \\
\hline & Chiller efficiency & $0.7 \mathrm{~kW} /$ ton \\
\hline & Heating System & Natural gas boiler \\
\hline & Reheat & Hot water reheat \\
& Boiler efficiency & $80 \%$ \\
\hline
\end{tabular}




\section{Appendix F - Comfort Survey}

\section{GSA High Performance Windows Study - Comfort Survey}

Instructions: Please check what applies and/or add clarification. Your name will not be mentioned in the results. The research team may follow up for additional information. If you have any question, please contact Kosol.Kiatreungwattana@nrel.gov

Name:

Email:

Phone:

1. Where are you located?

$\square$ Building 41

$\square$ Building 53

2. How close to a window do you sit to perform the majority of your work?

$\square$ Less than 15 feet

$\square$ 15-30 feet

$\square$ Greater than 30 feet

3. How often are you thermally uncomfortable? Please select all that apply.

\section{Before retrofit}

$\square$ Frequently too cold (4+ times per week)

$\square$ Occasionally too cold (1-2 times per week)

$\square$ Usually comfortable

$\square$ Occasionally too hot (1-2 times per week)

$\square$ Frequently too hot (4+ times per week)

After retrofit

$\square$ Frequently too cold (4+ times per week)

$\square$ Occasionally too cold (1-2 times per week)

$\square$ Usually comfortable

Occasionally too hot (1-2 times per week)

$\square$ Frequently too hot (4+ times per week)

4. Have you used a portable electric space heater in your workspace to increase comfort?
Before retrofit
$\square$ Yes
After retrofit
$\square$ No
$\square$ Yes
$\square$ No

5. Have you used a fan in your workspace to increase comfort?

Before retrofit

$\square$ Yes

After retrofit

$\square$ No

$\square$ Yes

$\square$ No

6. How many hours do you spend at your desk per day?

$\square 1$ to 3 hours 
$\square 3$ to 5 hours

$\square 5$ to 8 hours

$\square 8$ or more hours

7. What is your preferred position of the window in relation to your desk?

$\square$ Behind me

$\square$ To one of my sides

$\square$ In front of me, behind the computer screen

8. How often did windows cause visual discomfort such as glare?

Before retrofit

$\square$ Frequently too bright

$\square$ Occasionally too bright

$\square$ Never too bright
After retrofit

$\square$ Frequently too bright

$\square$ Occasionally too bright

$\square$ Never too bright

9. What is your preferred position for the window blinds in your workspace? Please select all that apply.

\section{Before retrofit}

$\square$ Up, clear window view

$\square$ Partially down

$\square$ Fully down

$\square$ No preference

$\square$ No window/blind in my workspace
After retrofit

$\square$ Up, clear window view

$\square$ Partially down

$\square$ Fully down

$\square$ No preference

$\square$ No window/blind in my workspace

10. How often do you adjust the position of the window blinds in your workspace?

\section{Before retrofit}

$\square$ Frequently adjust blinds

$\square$ Occasionally adjust blinds

$\square$ Never adjust blinds

$\square$ No window/blind in my workspace
After retrofit

$\square$ Frequently adjust blinds

$\square$ Occasionally adjust blinds

$\square$ Never adjust blinds

$\square$ No window/blind in my workspace

11. What factors motivate your adjustment of the window blinds in your workspace?

$\square$ Adjusting light level (glare control)

$\square$ Thermal management

$\square$ Privacy

$\square$ No window/blind in my workspace

12. Have you noticed the windows as being a cause of thermal discomfort before?

Before retrofit

$\square$ Yes, please describe:

$\square$ No

After retrofit

$\square$ Yes, please describe:

$\square$ No 
13. What garments do you typically wear in the office in the winter?

$\square$ Jacket

$\square$ Light sweater or long-sleeved top

$\square$ Short-sleeved top

14. What is your gender?

$\square$ Male

$\square$ Female

15. If you were to guess your metabolic rate while working, it would resemble which of the following for the majority of the time?
$\square$ Seated, quiet
$\square$ Standing relaxed
$\square$ Walking slowly
$\square$ Typing
$\square$ Lifting/packing

16. How would you characterize the visual appearance of the window retrofit?

$\square$ No noticeable difference in appearance

$\square$ Noticeable, but acceptable difference in appearance

$\square$ Negative impact on appearance

17. Based on your experience with the window retrofit in your building, would you recommend similar retrofits elsewhere?

$\square$ Strongly recommend

$\square$ Recommend

$\square$ No opinion

$\square$ Do not recommend 


\section{Appendix G - Additional Results for Medium Office}

Additional energy and economic analyses were conducted for the double-pane secondary window used in DOE's Commercial Reference Building Model for a medium-sized office constructed before 1980. Medium GSA utility rates was used to estimate the energy cost savings, payback, and SIR. Table 44 presents estimated energy savings, payback, and SIR of the double-pane secondary window. Table 45 summarizes the building characteristics of the DOE Commercial Reference Building Model for a medium office. The results and findings are summarized below.

- Normalized energy savings from 8.1-15.6 kBtu/ $\mathrm{ft}^{2} / \mathrm{yr}$

- Total building energy reduction between $11 \%$ and $18 \%$

- Normalized energy cost savings from $\$ 0.27-\$ 0.54 / \mathrm{ft}^{2} / \mathrm{yr}$ for medium utility rate

- Payback period from 5.6-11.2 years for medium utility rate

- $\quad$ SIR from 1.6-3.2 for medium utility rate.

Table 44: Estimated Energy, Normalized Energy Savings, Payback, and SIR of Double-Pane Secondary Window for Pre-1980 Medium Office

\begin{tabular}{|c|c|c|c|c|c|c|c|c|}
\hline & $\begin{array}{l}\text { Single- } \\
\text { Pane } \\
\text { Baseline } \\
\left(\mathrm{kBtu} / \mathrm{ft}^{2}\right)\end{array}$ & $\begin{array}{l}\text { Double- } \\
\text { Pane } \\
\text { Secondary } \\
\left(\mathrm{kBtu} / \mathrm{ft}^{2} \text { ) }\right.\end{array}$ & $\begin{array}{l}\text { Savings } \\
\left(\mathrm{kBtu} / \mathrm{ft}^{2}\right)\end{array}$ & $\begin{array}{l}\text { Whole } \\
\text { Building } \\
\text { Energy } \\
\text { Savings } \\
\text { (\%) }\end{array}$ & $\begin{array}{l}\text { Total } \\
\text { Energy } \\
\text { Cost } \\
\text { Savings } \\
\text { (\$) }\end{array}$ & $\begin{array}{c}\text { Normalized } \\
\text { Energy } \\
\text { Cost } \\
\text { Savings } \\
\left(\$ / \mathrm{ft}^{2}\right)\end{array}$ & $\begin{array}{c}\text { Payback } \\
\text { (yr) }\end{array}$ & SIR \\
\hline 1A Miami, Florida & 74.7 & 66.6 & 8.1 & $11 \%$ & $\$ 14,480$ & $\$ 0.27$ & 11.2 & 1.6 \\
\hline 2A Houston, Texas & 74.6 & 65.5 & 9.1 & $12 \%$ & $\$ 16,088$ & $\$ 0.30$ & 10.1 & 1.8 \\
\hline 2B Phoenix, Arizona & 76.1 & 65.4 & 10.7 & $14 \%$ & $\$ 19,031$ & $\$ 0.35$ & 8.7 & 2.1 \\
\hline 3A Atlanta, Georgia & 73.9 & 63.6 & 10.3 & $14 \%$ & $\$ 18,770$ & $\$ 0.35$ & 8.7 & 2.1 \\
\hline 3B Las Vegas, Nevada & 72.5 & 61.7 & 10.8 & $15 \%$ & $\$ 19,306$ & $\$ 0.36$ & 8.4 & 2.1 \\
\hline 3C San Francisco, California & 62.6 & 54.3 & 8.3 & $13 \%$ & $\$ 15,016$ & $\$ 0.28$ & 10.8 & 1.6 \\
\hline 4A Baltimore, Maryland & 78.3 & 65.7 & 12.6 & $16 \%$ & $\$ 23,060$ & $\$ 0.43$ & 7.1 & 2.5 \\
\hline 5A Chicago, Illinois & 81.1 & 67.6 & 13.5 & $17 \%$ & $\$ 24,669$ & $\$ 0.46$ & 6.6 & 2.7 \\
\hline 5B Boulder, Colorado & 79.1 & 65.2 & 13.9 & $18 \%$ & $\$ 25,205$ & $\$ 0.47$ & 6.5 & 2.8 \\
\hline 6A Minneapolis, Minnesota & 91.4 & 75.8 & 15.6 & $17 \%$ & $\$ 28,959$ & $\$ 0.54$ & 5.6 & 3.2 \\
\hline
\end{tabular}


Table 45: Summary of EnergyPlus Model for Medium Office

\begin{tabular}{|c|c|c|}
\hline \multicolumn{3}{|c|}{ Medium Office, Pre-1980 Vintage } \\
\hline & Weather Data & Climate Zone 5B \\
\hline & Building Type & Medium office \\
\hline & $\begin{array}{l}\text { Total Number of Buildings } \\
\text { Modeled }\end{array}$ & 1 \\
\hline & Building Areas & $53,628 \mathrm{ft}^{2}$ \\
\hline & Above-Grade Floors & 3 \\
\hline \multirow{6}{*}{ Building Footprint } & Building Orientation & Plan North \\
\hline & Zoning Pattern & Perimeter and core zones \\
\hline & Perimeter Zone Depth & $30 \mathrm{ft}$ \\
\hline & Floor to Floor Height & $14 \mathrm{ft}$ \\
\hline & Floor to Ceiling Height & $10 \mathrm{ft}$ \\
\hline & Roof Pitch & $0^{\circ}$, flat roof \\
\hline \multirow{3}{*}{ Roof } & Construction & Typical insulation entirely above deck roof \\
\hline & Roof & \\
\hline & Insulation & $\mathrm{R}-13.16$ \\
\hline \multirow{2}{*}{ Walls } & Construction & Typical insulated steel framed exterior wall \\
\hline & Exterior Insulation & Effective R-6.21 \\
\hline Exterior Doors & Door Type & Typical insulated metal door \\
\hline Exterior Windows & Window Type & Single pane window (baseline) \\
\hline $\begin{array}{l}\text { Window to Wall } \\
\text { Ratio }\end{array}$ & Gross Window-Wall Ratio & $33.01 \%$ \\
\hline $\begin{array}{l}\text { Building } \\
\text { Operation }\end{array}$ & Schedule & $\begin{array}{l}7 \text { a.m. to } 5 \text { p.m., Mon-Fri; closed on the } \\
\text { weekends }\end{array}$ \\
\hline \multirow[t]{2}{*}{ Power Density } & Lighting & $1.57 \mathrm{~W} / \mathrm{ft}^{2}$ \\
\hline & Plug Loads & $1.0 \mathrm{~W} / \mathrm{ft}^{2}$ \\
\hline \multirow[t]{5}{*}{ HVAC Systems } & System Type & Packaged variable air volume system \\
\hline & Cooling System & Direct expansion \\
\hline & Cooling Efficiency & $3.22 \mathrm{COP}$ \\
\hline & Heating System & Natural gas furnace \\
\hline & Furnace Efficiency & $78 \%$ \\
\hline
\end{tabular}

